\title{
Jesuits in Spanish America before the Suppression
}

\section{Organization and Demographic and Quantitative Perspectives}

\author{
Robert H.Jackson \\ Independent scholar \\ robertvianey@gmail.com
}

\begin{abstract}
From the late sixteenth century until their expulsion in 1767 , members of the Society of Jesus played an important role in the urban life of Spanish America and as administrators of frontier missions. This study examines the organization of the Society of Jesus in Spanish America in large provinces, as well as the different urban institutions such as colegios and frontier missions. It outlines the spiritual and educational activities in cities. The Jesuits supported the royal initiative to evangelize indigenous populations on the frontiers, and particularly the outcomes that did not always conform to expectations. One reason for this was the effects of diseases such as smallpox on the indigenous populations. Finally, it examines the 1767 expulsion of the Jesuits from Spanish territories. Some died before leaving the Americas or at sea. The majority reached Spain and were later shipped to exile in the Papal States.
\end{abstract}

\section{Keywords}

Society of Jesus - education - misión popular - colegios - frontier missions - Guaraní Sonora-Sinaloa - Chaco - Baja California - expulsion

\section{Introduction}

The 1759 publication of the novel Candide, ou l'optimisme (Candide, or optimism) by Voltaire (François-Marie Arouet [1694-1778]) provided contemporary literate Europeans with what was one of their few views of the activities of the Society of Jesus (Jesuits) in Spanish America. The novel also created the notion that the missions established among the Guaraní in the Río de la Plata 
region of South America functioned as a type of socialist republic based on the belief that the Jesuits controlled production on the missions and distributed food to the Guaraní. ${ }^{1}$ However, the reality of Jesuit activities in Spanish America was quite different. The Guaraní mission residents worked their own subsistence plots to produce for their own needs and provided labor for communal projects; the Jesuits did not use communal production to feed and clothe them.

Candide was published at a time of dramatic change for the Society of Jesus - after coming under attack from reformist monarchs, the Jesuits were eventually expelled from Portugal in 1759, France in 1764 , and Spain in 1767 , a process that culminated in the pope's suppression of the order in 1773. However, forty years later, in 1814, the pope restored the order, and it continues to exist today. The sitting pope, Francis I (r.2013-), is a Jesuit originally from Argentina.

In the sixteenth and seventeenth centuries, the Jesuit superiors general sent missionaries to the Americas, Africa, and Asia. Jesuits found their way to Huronia in the French colony in Canada, the ancient kingdom of Ethiopia, Goa and other Portuguese outposts in India, the Ming dynasty court in China, and Japan, where they baptized thousands until the government initiated an anti-Christian persecution that ultimately resulted in the expulsion of most Europeans and a policy of isolation that lasted for several centuries. The first act of persecution was the 1597 crucifixion in Nagasaki of Japanese Christians and a handful of foreign missionaries, a total of twenty-six men including three Japanese Jesuits. One was the Franciscan Felipe de Jesús (1572-97), who was a native of Mexico City. Forty years later, the Jesuits established a mission in the Guaraní village of Caaró (Rio Grande do Sul, Brazil), which they named Los Santos Mártires del Japón to commemorate the Nagasaki martyrs. The Jesuits also came to the Spanish territories in the Americas. They arrived in Lima in the viceroyalty of Peru in 1568 and the viceroyalty of Nueva España four years later in 1572.

Jesuits also died in Spanish America, and Gonzalo de Tapia (1561-94) was one of the first to be martyred in Mexico. In 159o, he established a mission named San Luis de la Paz in what today is southern Guanajuato as part of a

1 See, for example, Robert Bontine Cunninghame Graham, A Vanished Arcadia: Being Some Account of the Jesuits in Paraguay 1607-1767 (London: William Heinemann, 1901); William Henry Koebel and Robert Bontine Cunninghame Graham, In Jesuit Land: The Jesuit Missions of Paraguay (London: S. Paul, 1912); Philip Caraman, The Lost Paradise: The Jesuit Republic in South America (New York: Seabury Press, 1976); Walter Nonneman, "On the Economics of the Socialist Theocracy of the Jesuits in Paraguay (1609-1767)," in The Political Economy of Theocracy, ed. Ronald Wintrobe and Mario Ferrero (New York: Palgrave Macmillan, 20o9), $119-42$. 


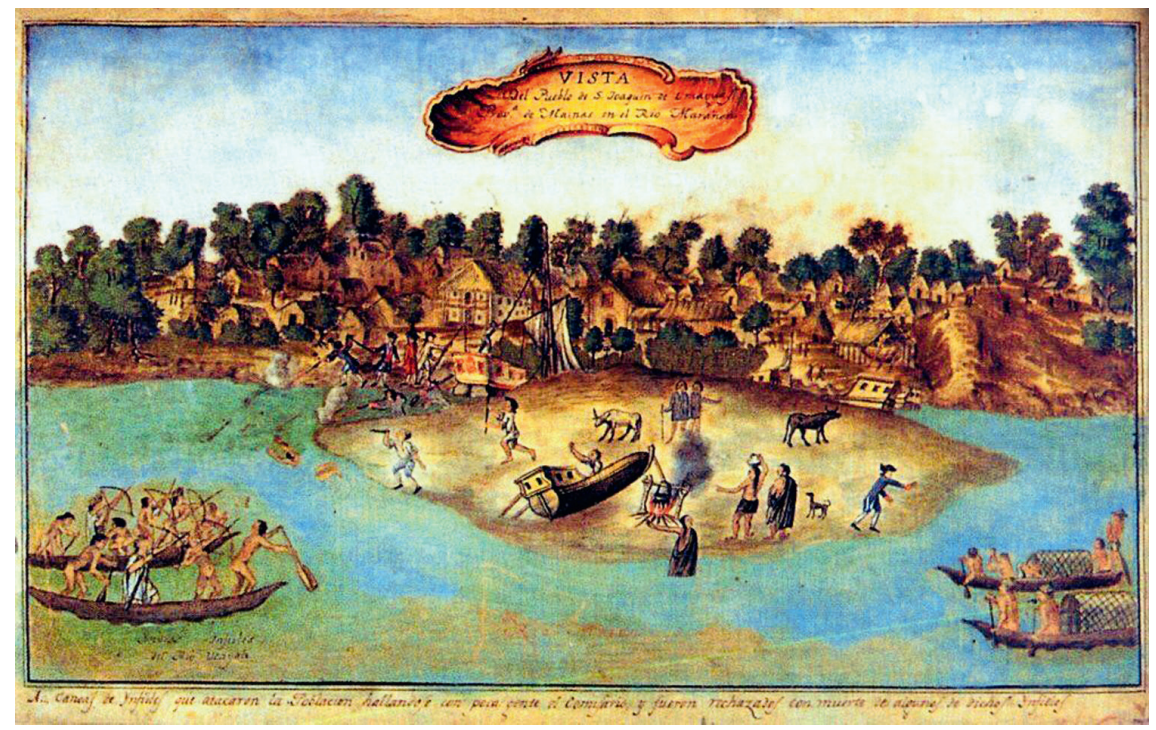

FIGURE 1 An attack by hostile natives on San Joaquín de Omaguas mission

larger strategy to use the missions to try to pacify the groups collectively known as Chichimecas after decades of a failed military campaign of pacification.

In 1594, Tapia's superiors sent him to the new missions in northern Sinaloa, where he had a shaman flogged as part of the Jesuit strategy of challenging the authority of traditional religious leaders and publicly humiliating them. However, the leaders of the traditional faction had him killed. ${ }^{2}$ A modern statue at the site of San Luis de la Paz commemorates his life and martyrdom.

There were also instances of collective resistance to Jesuit missions and the Spanish colonial regime they represented. There were uprisings on missions as well as attacks by hostile indigenous groups. A contemporary illustration, for example, documents an attack on the San Joaquín de Omaguas mission located in the Amazon River Basin (see fig. 1).

This study outlines Jesuit activities in the Spanish territories in the Americas from the sixteenth century up to the point of their expulsion in 1767 , and particularly their missionary activities on the fringes of Spanish American territory. Section 2 discusses the Jesuit administrative and economic organization in Spanish America and the system of recordkeeping. The Jesuits left an extensive corpus of written documents that are useful for reconstructing their activities in Spanish America. This record includes letters as well as reports written

2 Robert H. Jackson, A Visual Catalog of Spanish Frontier Missions, 16th to 19th Centuries (Newcastle upon Tyne: Cambridge Scholars Publishing, 2018), 62, 282. 
for their superiors within the order and royal officials. Section 3 outlines the urban institutions and the economic system that financed their activities. Sections 4 to 6 analyze missions established on the fringes of Spanish territory in the Americas in order to show how the Jesuits adapted their mission programs to the different indigenous forms of social and political organization and the ways in which the frontier missions functioned in concert with Spanish policy objectives. Section 4 examines the missions among the sedentary Guaraní in the Río de la Plata region of South America; as we will see, this group of missions most closely achieved the Spanish goal of creating stable indigenous communities on the frontier. Section 5 looks at the Sinaloa and Sonora missions located on the northwestern frontier of Mexico. Section 6 explores missions among non-sedentary indigenous groups on the Río de la Plata frontier and Baja California on the northern frontier of Mexico. Section 7 documents the Jesuits' expulsion from Spanish America and the problem royal officials faced in staffing the former Jesuit missions. Section 8 provides a concluding summary of the historical importance of the Society of Jesus in Spanish America through a focus on its role in education, staffing the missions, and cultural life.

\section{The Jesuit Organization and Recordkeeping in Spanish America}

Unlike the other religious orders in Spanish America, such as the Franciscans, Dominicans, and Augustinians, which had separate national-level administrative units from which members sent to the Americas were recruited, the Society of Jesus recruited its members internationally. This is reflected in several examples from the Baja California missions in northern Mexico: foreign-born missionaries there included the Scotsman William Gordon (dates unknown), the Croat Fernando (Fernan) Konsag (1703-59), and the Bohemian Wenceslao Linck (1736-90?). Ignaz Tirsch (1733-81) and Florian Pauck (1719-8o), the first also stationed on the Baja California missions and the second named sent to the Chaco missions in southern South America, were artists who left a visual record of what they saw in the Americas. The Jesuits also had to pass through a longer period of intellectual and spiritual training before taking their final vows when compared with the members of the other religious orders that came to Spanish America.

The Jesuits developed their different activities in a variety of institutions. This included the urban institutions, with the Jesuits investing considerable sums in the construction of large building complexes that generally occupied strategic locations in city centers. The Jesuits played an important role 
in colonial Spanish American cities. Their churches catered to city-folk, they educated the children of wealthy citizens and the indigenous elites, and organized urban missions known as "popular missions." One institution was the colegio mayor, which was a university that focused on the teaching of theology and philosophy. There would also have been a convictorio (domus convictorum) or residence for the university students who did not have a place to live. One example was the Colegio Máximo de San Pedro y San Pablo located in Mexico City (see fig. 2). A second institution was the colegio menor, which generally taught grammar. The Jesuits established three colegios in Mexico City in the same large block as the colegio máximo (see fig. 3). One was the Colegio de San Ildefonso, a second the Colegio de San Gregorio founded in 1573 to educate the children of the indigenous elite, and another named the Colegio de San Andrés. The indigenous population of Tacuba initially supported San Gregorio, but in the late seventeenth century Juan de Chavarria Valera (dates unknown) donated thirty-four thousand pesos and the hacienda of San José de Acolman for the construction of a church erected from 1682 to $1685^{3}{ }^{3}$

There were also casas profesas or a place of residence for the Jesuit priests who had taken four vows. An example was the casa profesa in Mexico City of which only the church survives. During the Jesuit tenure, the church was named San José el Real, but following the Jesuit expulsion royal officials reassigned the church and adjoining complex and it was renamed the Oratorio de San Felipe Neri. It is popularly known today as "La Profesa" (see fig. 4). Other Jesuit institutions included the casa de ejercicios, which were devotional centers for laypeople segregated by gender. Finally, there were noviciados (domus probationis, novitiatus) or novitiates for the training of young men who wished to join the order. An example of a novitiate is that of San Francisco Xavier, located in Tepotzotlán (Estado de México, México) (see fig. 5). A residencia was a Jesuit installation that did not have the status of a colegio but established a Jesuit presence in an urban center. ${ }^{4}$

The Jesuits developed an extensive economic system to finance their urban and missionary activities. One type of operation was an income-producing rural estate that produced different products. In the river valleys of southern

3 Luisa Elena Alcalá, Patricia Díaz Cayeros, and Gabriela Sánchez Reyes, "Solemne procesión a la imagen de Nuestra Señora de Loreto: La epidemia de sarampión en 1727," Encrucijada 1 (2009): 22-51.

4 Carlos Page, "Los planos de los colegios jesuíticos de Lima, Ayacucho, y Sucre de la Biblioteca Nacional de Francia," ALTERITAS: Revista de estudios socioculturales Andino Amazónicos 8, no. 9 (2019): 247-62. 

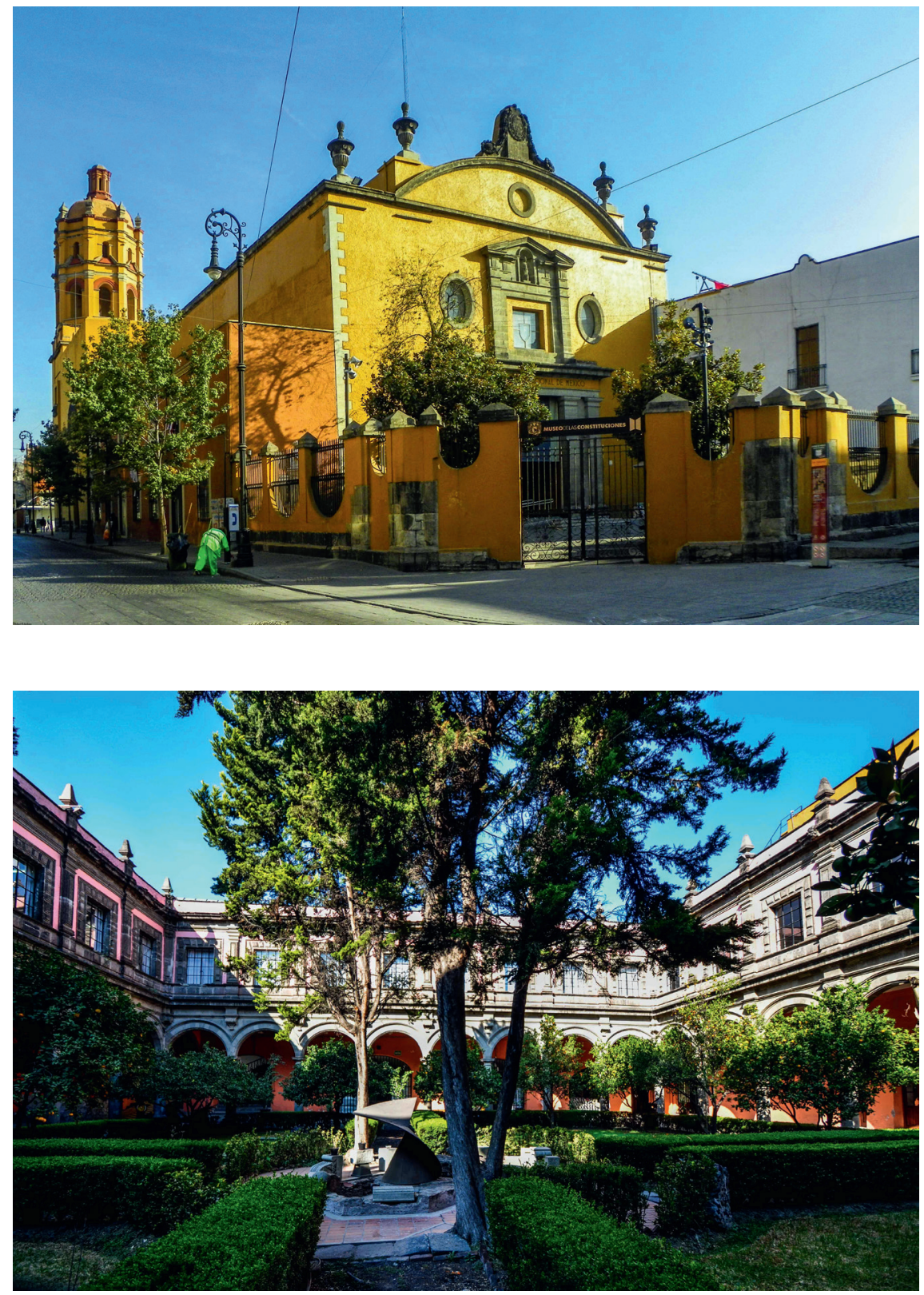

figure 2 The Colegio Máximo de San Pedro y San Pablo (Mexico City) 


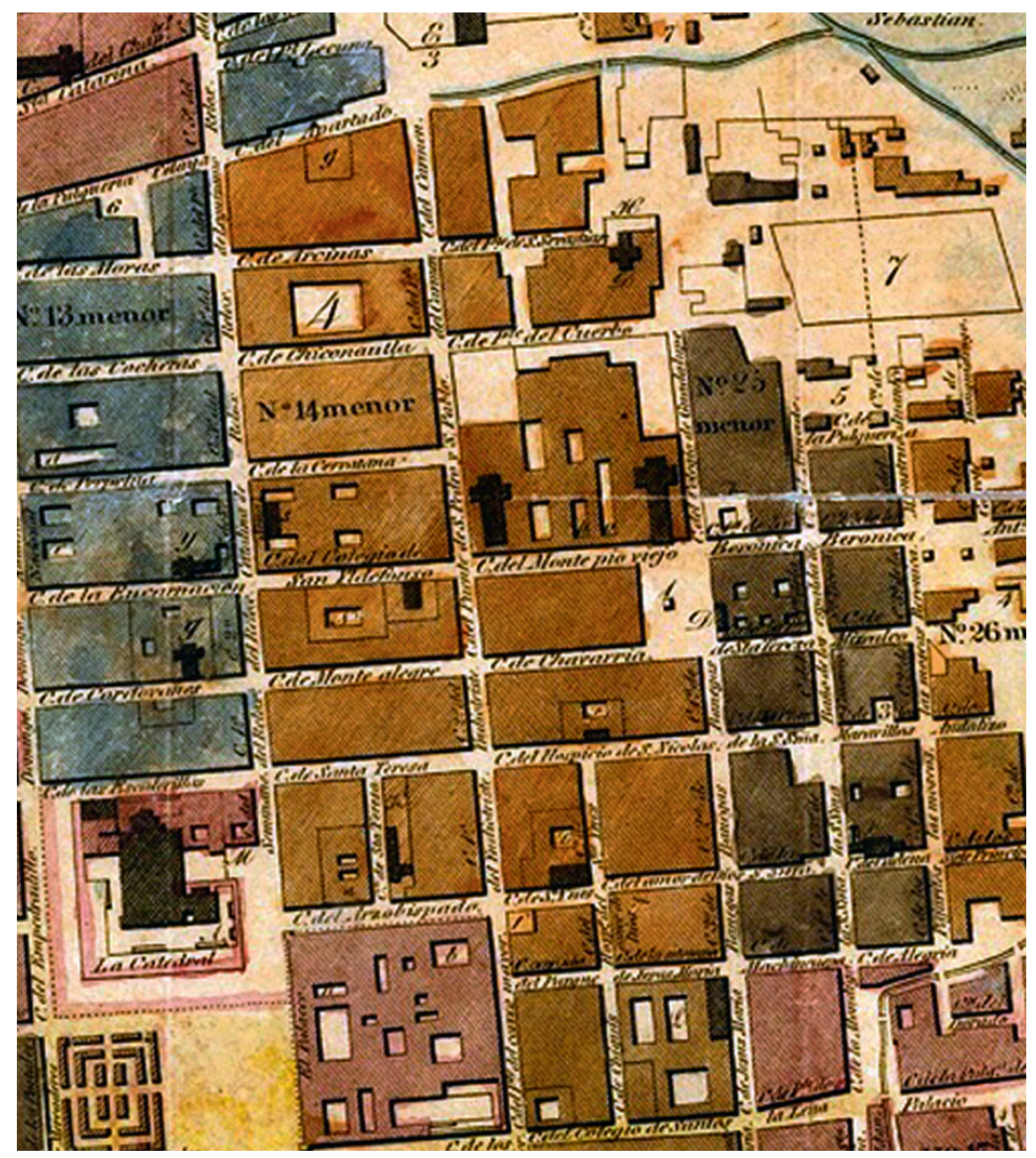

FIGURE 3 Detail of a 1793 map of Mexico City showing the ex-Jesuit complex 

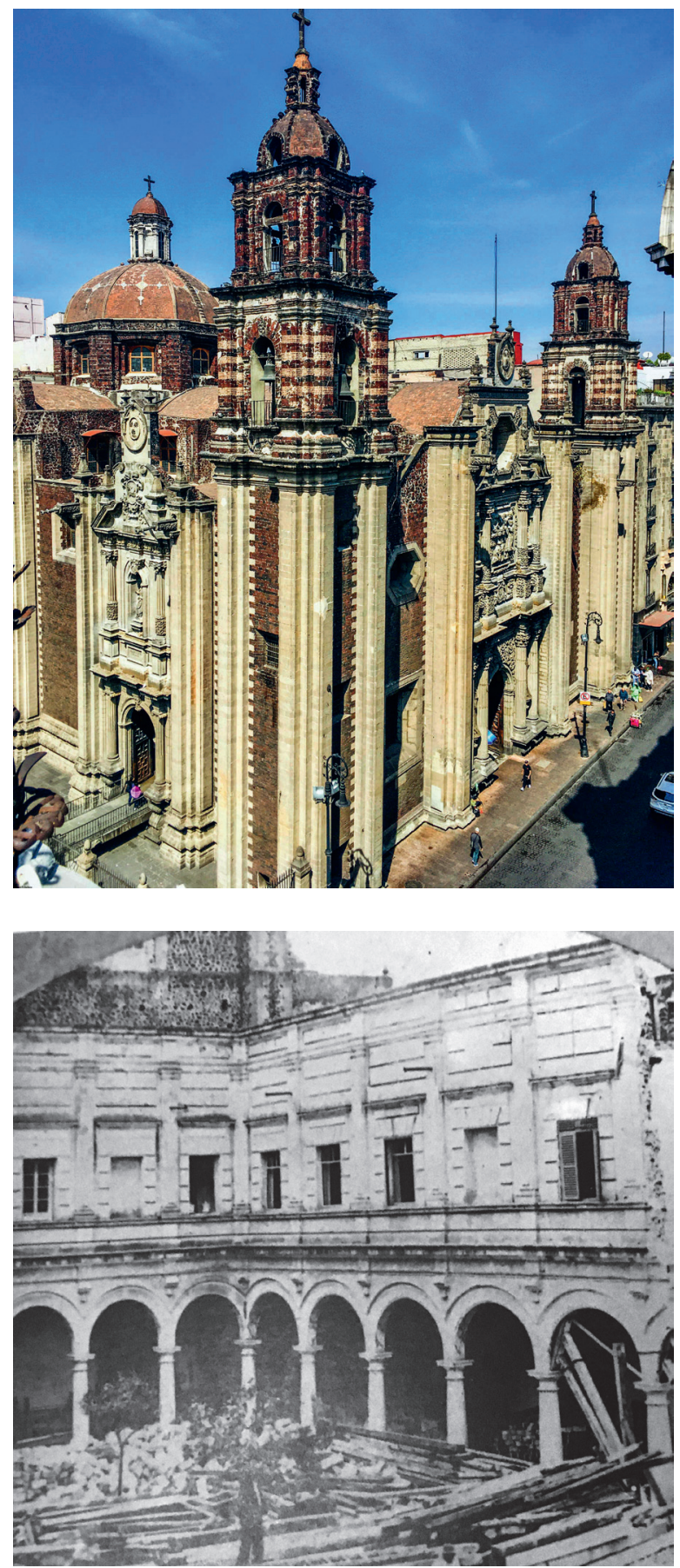

FIGURE 4 The church of the casa de profesa in Mexico City 


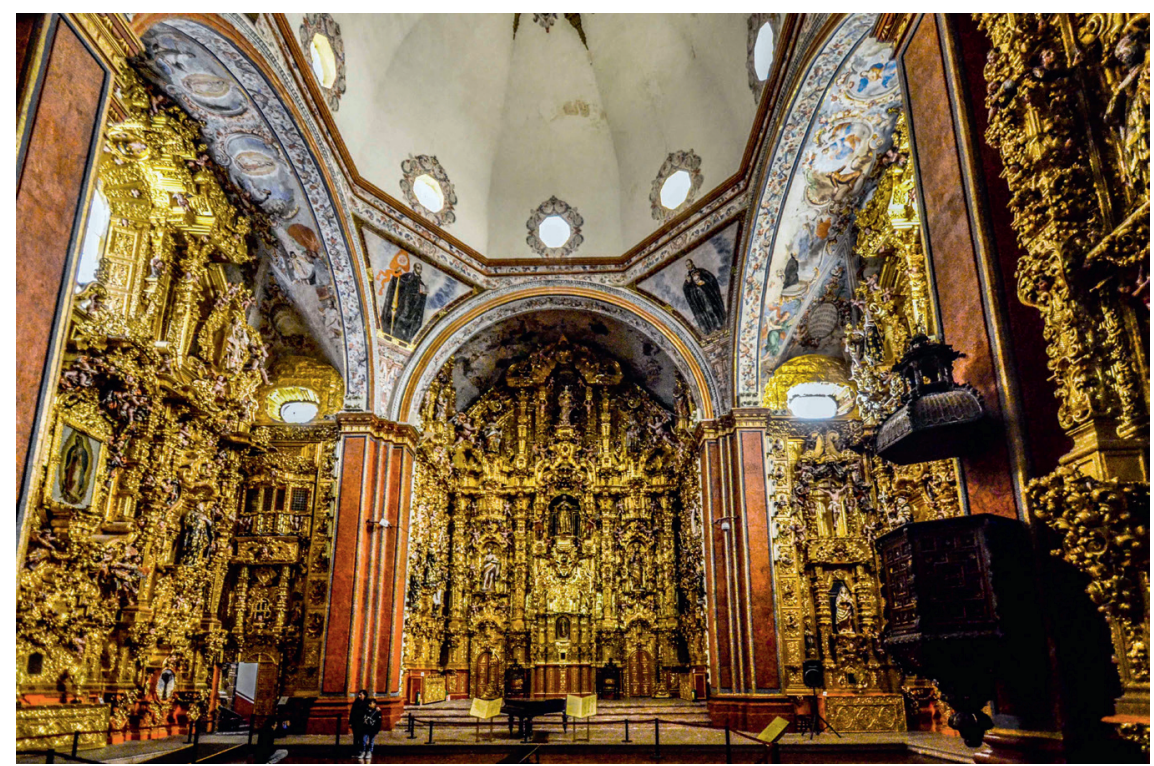

FIGURE 5 The interior of San Francisco Xavier church of the colegio and novitiate at Tepotzotlán

Peru, there were Jesuit-owned sugar estates worked, in part, by slave labor. ${ }^{5}$ A second example was textile mills known as obrajes that operated in cities such as Quito in what today is Ecuador. ${ }^{6}$ A third example was Jesuit-owned ranches located in what today is northern Argentina that bred mules for sale in Upper Peru (Bolivia), and particularly in mines such as Potosí. ${ }^{7}$

In addition to the urban institutions, there were also Jesuit frontier missions to indigenous peoples in the provincial administrative unit. Typical was the province of Paraquaria, which included parts of what today are the modern countries of Argentina, Uruguay, Brazil, Paraguay, and Bolivia. There were colegios in a number of the major urban centers, including Buenos Aires, and farming and ranching operations as well as missions. Paraquaria had a number of groups of missions including those among the Guaraní, on the Pampas and Chaco frontiers, and in the Chiquitania region of eastern Bolivia in what today is the Santa Cruz Department.

5 Nicholas Cushner, Lords of the Land: Sugar, Wine, and Jesuit Estates of Coastal Peru, 1600-1767 (Albany, NY: SUnY Press, 1980).

6 Nicholas Cushner, Farm and Factory: The Jesuits and the Development of Agrarian Capitalism in Colonial Quito (Albany, NY: SUnY Press, 1982).

7 Nicholas Cushner, Jesuit Ranches and the Agrarian Development of Colonial Argentina, 16501767 (Albany, NY: sunY Press, 1984). 
There was a separate administrative and economic system for the missions. There were offices in major urban centers known as oficio de misiones/ procuradurías that marketed goods produced by Jesuit operations and also procured goods. ${ }^{8}$ The Jesuits stationed on the Chiquitos missions, for example, did business with the office in Potosí, while the missions among the Guaraní did business with the offices in Buenos Aires and Santa Fe. In the case of the missions established after 1697 in Baja California in northern Mexico, the Jesuits assumed complete responsibility for all the costs of administration including the salaries and expenses of the military personnel. The crown accepted this arrangement after its own colonization attempts failed. ${ }^{9}$

A $175^{\circ}$ inspection documented the extent of the Jesuit presence in Spanish America seventeen years before the expulsion order. Altogether, and including the Philippines, which was an appendage of Mexico, there were 2,221 Jesuits, eighty-three colegios, thirty-two residencias, and twenty-one mission rectorates. The Mexican province, which also included parts of Central America and the Caribbean including Guatemala and Cuba, counted the largest number of Jesuits with 622 . The province consisted of twenty-three colegios, five residencias, and seven mission rectorates (see table 1). The number in Mexico increased up to the point of the expulsion order (see table 2). The two urban centers with the largest presence were Mexico City and Puebla de los Ángeles (see table 3). Peru was second in $175^{\circ}$ in terms of the total numbers with $5^{26}$ Jesuits, fifteen colegios, and three residencias. The province of Paraquaria ranked third in the number of Jesuits, which reflected the importance of its seven mission rectorates. The number of Jesuits totaled 303; there were ten colegios and one residencia (see Map 1).

The Jesuits left an extensive written record of their activities in Spanish America in letters and reports drafted for their superiors in the order and colonial officials, as well as other documents. The provincials that administered

8 Cynthia Radding de Murrieta, "From the Counting House to the Field and Loom: Ecologies, Cultures, and Economics in the Missions of Sonora (Mexico) and Chiquitanía (Bolivia)," Hispanic American Historical Review 81, no. 1 (2001): 45-87; David Block, "Links to the Frontier: Jesuit Supply of Its Moxos Missions, 1683-1767," Americas 37, no. 2 (1980): 161-78.

9 See, for example, Peter Masten Dunne, S.J., Black Robes in Lower California (Berkeley: University of California Press, 1952); Ignacio del Río, Conquista y aculturación en la California jesuítica, 1697-1768 (Mexico City: Instituto de Investigaciones Históricas, Universidad Nacional Autónoma de México, 1984); del Río, El régimen jesuítico de la Antigua California (Mexico City: Instituto de Investigaciones Históricas, Universidad Nacional Autónoma de México, 2003); Robert H. Jackson, Missions and Frontiers of Spanish America: A Comparative Study of the Impact of Environmental, Economic, Political, and Socio-Cultural Variations on the Missions in the Río de la Plata Region and on the Northern Frontier of New Spain (Scottsdale, AZ: Pentacle Press, 2005). 
TABLE 1 The number of Jesuits in Spanish America in $175^{\circ}$

\begin{tabular}{lcccc}
\hline Province & Number of Jesuits & Colegios & Residencias & Mission rectorates \\
\hline Peru & 526 & 15 & 3 & \\
Chile & 242 & 10 & 10 & \\
Nueva Granada & 193 & 9 & 1 & 9 \\
México & 622 & 23 & 5 & 7 \\
Paraguay & 303 & 10 & 1 & 4 \\
Quito & 209 & 11 & & 1 \\
Philippines & $\mathbf{1 2 6}$ & 5 & 12 & $\mathbf{2 1}$ \\
Total & $\mathbf{2 , 2 2 1}$ & 83 & $\mathbf{3 2}$ & \\
\hline
\end{tabular}

SOURCE: MARIA CRISTINA TORALES PACHECO, "LA PROVINCIA JESUITA DE NUEVA ESPAÑA: CRIOLLISMO E IDENTIDAD," IN JESUITAS EN LAS AMÉRICAS: PRESENCIA EN EL TIEMPO, ED. JORGE TROISI MELEAN AND MARCIA AMANTINO (BUENOS AIRES: TESEOPRESS, 2019), 91-125.

TABLE 2 The number of Jesuits in Mexico in selected years

\begin{tabular}{llll}
\hline Year & Number of Jesuits & Year & Number of Jesuits \\
\hline 1680 & 387 & 1708 & 509 \\
1687 & 412 & 1714 & 510 \\
1690 & 451 & 1750 & 622 \\
1693 & 484 & 1764 & 675 \\
1698 & 513 & 1767 & 678 \\
\hline
\end{tabular}

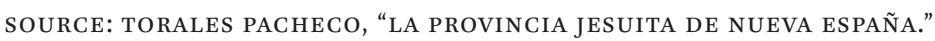

TABLE 3 The number of Jesuits in Mexico in 1750

Urban Institutions

Priests Brothers

Casa profesa (Mexico City)

18

13

Colegio Máximo de San Pedro y San Pablo (Mexico City)

$38 \quad 15$ and 38

Colegio de San Andrés (Mexico City) escolares

Colegio de San Gregorio (Mexico City)

$12 \quad 17$

Seminario de San Ildefonso (Mexico City)

62

$2 \quad 0$


TABLE 3 The number of Jesuits in Mexico in 175 (cont.)

Urban Institutions $\quad$ Priests Brothers

Colegio and Novitiate of San Francisco Xavier (Tepotzotlán) $10 \quad 20$

$\begin{array}{lll}\text { Colegio de Espiritu Santo (Puebla) } & 40 & 17\end{array}$

Colegio de San Ildefonso (Puebla) $\quad 15 \quad 6$

Colegio de San Francisco Xavier (Puebla) $\quad 8 \quad 3$

Seminario de San Ignacio (Puebla) $\quad 2 \quad 0$

Seminario de San Jerónimo (Puebla) $\quad 1 \quad 0$

$\begin{array}{lll}\text { Colegio de San Ignacio (Querétaro) } & 7 & 3\end{array}$

Seminario de Querétaro $\quad 1 \quad$ o

Colegio de la Santísima Trinidad (Guanajuato) $\quad 4 \quad 2$

Colegio de San Luis de la Paz (Guanajuato) $\quad 5 \quad$

Colegio de San Ignacio (San Luis Potosí) $\quad 5 \quad 3$

Colegio de la Purísima Concepción (Zacatecas) $\quad 6 \quad 3$

$\begin{array}{lll}\text { Colegio de Santo Tomás (Guadalajara) } & 7 & 3\end{array}$

Seminario de San Juan Bautista (Guadalajara) $\quad 1 \quad$ o

Colegio de San Francisco Xavier (Valladolid-Morelia) $\quad 8 \quad 1$

Colegio de Veracruz $\quad 5 \quad 2$

Colegio de San Francisco Xavier (Mérida) $\quad 8 \quad 1$

Colegio de San Ignacio (Pátzcuaro) $\quad 4 \quad 1$

Colegio de la Inmaculada Concepción (Antequera-Oaxaca) $8 \quad 2$

Colegio de Celaya (Guanajuato) $\quad 5 \quad 1$

Colegio de Ciudad Real (Chiapas) $\quad 5 \quad 1$

Colegio de Durango $\quad 6 \quad 1$

Residencia de León (Guanajuato) $\quad 5 \quad 2$

Residencia Chihuahua $\quad 4 \quad 1$

Residencia de San José (Campeche) 44

Residencia de Parral (Coahuila) 11

Residencia de Parras (Coahuila) 3 o

Outside of modern Mexico

Colegio de Guatemala (Antigua, Guatemala) $\quad 8 \quad 2$

Seminario de San Francisco de Borja (Antigua, Guatemala) $1 \quad 1 \quad$

Colegio de Havana (Cuba) $\quad 8 \quad 2$

Residencia de Puerto Príncipe (Haiti) 220

Missions in northern Mexico

Nayarit $\quad 6 \quad 0$

Piastla $\quad 10 \quad 0$

Sinaloa $\quad 16 \quad 16$ 
TABLE 3 The number of Jesuits in Mexico in 1750 (cont.)

\begin{tabular}{lcc} 
Urban Institutions & Priests & Brothers \\
\hline Tepehuanes & 11 & 0 \\
Tarahumara & 13 & 0 \\
Chinipas & 7 & 0 \\
Sonora & 18 & 0 \\
Pimería Alta (Sonora) & 9 & 0 \\
California & 13 & 0 \\
\hline
\end{tabular}

Source: torales PaCheco, "LA PRovincia Jesuita de NUEVA ESPaÑa."

the provinces also drafted periodic reports. One of the most useful is the carta anua, which is a narrative account of activities and important events within the province such as epidemics. Some cartas anuas also appended censuses. The provincials wrote the narrative reports for their superiors in Rome, and a number of the cartas anuas are preserved in the Archivum Romanum Societatis Iesu in Rome, which is the main repository of Jesuit documents maintained by the order's central administration. The Jesuits also maintained detailed accounts of their economic activities and prepared individual reports on the institutions within the province such as the colegios and missions. The Jesuits left a detailed written record about the missions in the province of Paraquaria, for example, including censuses. The recordkeeping evolved over time, and in the case of the mission population, counts took standardized form by the $1720 \mathrm{os}$. The Jesuits prepared an anua or report for each mission, which was in turn sent to the head of the missions who had a general report prepared. Individual mission reports also exist in the eighteenth century for the Chiquitos and Chaco missions.

Early censuses reported only the population and the number of families. In the seventeenth century, the missionaries did not always provide complete information such as the population or the number of sacraments administered. In 1678, for example, the report on Yapeyú did not include the mission population, and the same happened in the summaries of the anuas of several missions in $1671 .^{10}$ During most of the seventeenth century, the reports were

10 "Carta annua de las doctrinas del Parana y Uruguay de 1678," Coleção de Angelis, Biblioteca Nacional, Rio de Janeiro (hereafter cited as CA); "Carta annua de las d[octrin] as del Parana y Uruguay de 1671 ," CA. For an example of an individual mission report, see "Anua de la doctr[in]a del Corpus Christi del año de 1675," CA. 


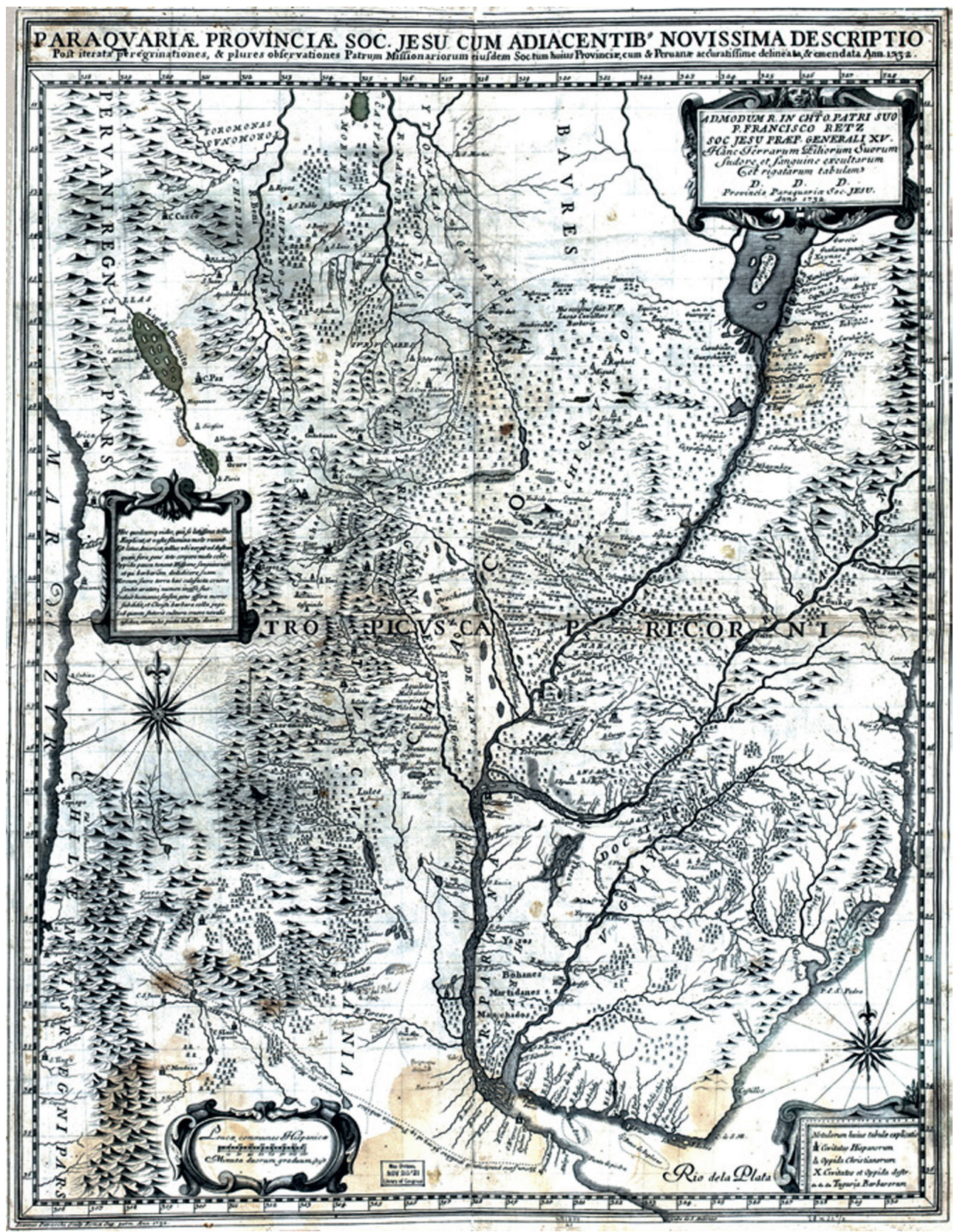

MAP 1 A 1732 map of the Jesuit province of Paraguay. 
prepared in a narrative format and included demographic information. It was not until the 169os that the reports also included tables summarizing population data, and this did not become standard practice until the early eighteenth century. In some instances, the Jesuits prepared separate reports on the Paraná and Uruguay missions among the Guaraní, and in some cases both have not survived. This occurred, for example, in 1705, 1711, and for several years in the 169os such as $1695 .{ }^{11}$

Starting in 1714, the Jesuits adopted the practice of preparing a single general census for all of the missions among the Guaraní, and they also did the same for the population counts of the Chiquitos missions. The existing counts are in three formats. Some were written in Latin and accompanied the cartas anuas, which were also written in Latin. The second format, which was written in Spanish, is more useful, because it also summarizes the number of sacraments administered. The Jesuits standardized the format in the 1720 and after 1748 included information on the Tarima missions. There are also some censuses summarizing the population data for all the missions in the province of Paraguay, including the Chiquitos missions, the Chaco missions, the Tarima missions, and the mission established among the Chiriguanos. They exist for $1710,1736,1745,1757$, and 1762 and also accompanied reports sent to Rome. They were either written in Latin or Spanish and documented the expansion of missionary activity in the province of Paraguay. The 1710 census, for example, enumerates the populations of the missions among the Guaraní and the Chiquitos establishments. ${ }^{12}$

The Jesuits also prepared detailed tribute censuses at the request of royal officials that generally categorized the population by family group and cacicazgo (the jurisdiction of the clan chiefs) and estimated ages. In the case of natives born on the missions, the ages reported are fairly accurate. However, the Jesuits generally estimated the ages for those individuals congregated on the missions and often rounded the numbers off. These censuses exist for several years for the missions among the Guaraní such as 1715, 1735, 1759, and for several years following the Jesuit expulsion in $1767 / 68$. There is a complete set of tribute records for the Chiquitos missions for the year 1745 that is useful for reconstructing the social and family structure of the mission populations.

During the colonial period, members of the different missionary orders wrote chronicles of the activities of their orders. In the case of frontier

111705 is an example. The report for the Uruguay missions exists, but not for the Paraná missions. See "Estado general de las doctrinas del Uruguay del año de 1705," CA.

12 "Catalogus missionum provincia Paraguaria Soc. Iesu anno 1710," Archivum Romanum Societatis Iesu, Rome (hereafter cited as ARSI). 
missions, it was not uncommon for the chroniclers to have never visited the missions and to have instead written narratives based on reports and letters sent by missionaries stationed on the missions. Two Jesuit chroniclers, Miguel Venegas (168o-1764) and Francisco Javier Clavijero (1731-87), wrote accounts of the Baja California missions that were typical of the genre. ${ }^{13}$ The accounts of the Baja California missions also offer an unusual example of one of the Jesuit missionaries who wrote his own chronicle to rebut what his confrère had written. Miguel del Barco (1706-90), stationed for many years on San Francisco Xavier mission, wrote his text Historia natural y crónica de la Antigua California: Adiciones y correcciones a la noticia de Miguel Venegas (Natural history and chronicle of old California: Additions and corrections to the notice of Miguel Venegas) to correct what he viewed as errors in the official chronicle of Venegas, who had never set foot in Baja California. ${ }^{14}$ These chronicles nevertheless provide important and useful information, as well as insights into the mentality of the Jesuits themselves and particularly their attitudes toward the evangelization process on the missions they staffed.

\subsection{Conclusions}

The Jesuits established an extensive network of urban institutions and frontier missions. Their importance to Spanish American colonial society greatly outweighed their numbers. They established urban colegios and, as is discussed in the following section, educated and provided for the spiritual needs of urban folk. They also staffed frontier missions, the most important of which were in the province of Paraquaria in parts of South America. We know a great deal about their activities because of the extensive records they left, such as the cartas anuas or narrative reports that provide considerable details of their activities but also clues about what the Jesuits themselves believed and thought.

\section{Good Times, Bad Times: The Urban Role of the Jesuits}

The Jesuits played an educational and evangelical role in the cities of Spanish America. They also served as intermediaries to a vengeful God who punished

13 Miguel Venegas, Noticia de la California, y de su conquista temporal, y espiritual hasta el tiempo presente: Sacada de la historia manuscrita, formada en México año de 1739 (Valladolid: Editorial Maxtor, 2013); Francisco Javier Clavijero, Historia de la Antigua o Baja California (Mexico City: Imprenta de Juan R. Navarro, 1852).

14 Miguel del Barco, Historia natural y crónica de la Antigua California: Adiciones y correcciones a la noticia de Miguel Venegas; Edición, estudio preliminar, notas y apéndices; Miguel León-Portilla (Mexico City: Universidad Nacional Autónoma de México, Instituto de Investigaciones Históricas, 1973). 
sin by sending epidemics and causing adverse weather, or at least that is what the Jesuits believed. This section begins with a description of how the Jesuits responded to one of the bad times in Mexico City, a 1726-27 measles epidemic. The identification of bacteria and viruses as the cause of disease was still more than a century in the future, and Western medicine still had a basis in the classical humoral theory that postulated that disease occurred as a result of an imbalance of four fluids in the body, or the miasma theory that maintained that clouds of noxious gas infected people. The Jesuits maintained that sinful behavior brought on God's wrath, and that acts of devotion were necessary to placate that wrath.

Highly contagious crowd diseases such as measles spread through the population when there was a large enough number of susceptible hosts to maintain the chain of infection, which generally were the people not previously exposed to the contagion. Epidemics often spread in times of societal stress. In the years before the outbreak, there had been shortages of corn in Mexico City as a result of adverse weather and speculation. In 1724-26, for example, there had been shortages of both corn and meat. ${ }^{15}$ Measles broke out in the city in 1726 and continued into 1727. During the epidemic, the Jesuits attended to the sick and dying, giving the last rites as well as providing food, medicine, and clothing to the poor and indigent. In September 1727, the Jesuits organized a novena, nine days of devotion and prayer, in the cathedral, and a procession through the streets of the city that is depicted in a painting found in the church of San Pedro Apóstol in San Pedro Zacatenco (see fig. 6). As part of the acts of devotion, the "Black Robes" took the statue of the Virgin of Loreto from San Gregorio church to the cathedral and then staged a procession with the statue. In some cases, penitents engaging in self-flagellation participated in processions, but the 1727 event did not include mortification of the body. In the months following the procession, the outbreak abated, and in January 1728 the Gaceta de Mexico (The Mexico gazette) reported that the epidemic had ended in the city. ${ }^{16}$ However, the contagion then spread to other parts of Mexico.

Jesuit sources detail the activities of the urban colegios. For the purposes of this study, I examine the case study of the colegios in the province of Paraquaria in South America in the 1730 os and 1740s. First, I provide an overview of the institutions in the cities of the region. At the time, these were small communities. In 1744, for example, Buenos Aires reportedly had a population of 10,056,

\footnotetext{
15 Alcalá, Díaz Cayeros, and Sánchez Reyes, "Solemne procesión a la imagen de Nuestra Señora de Loreto," 28.

16 Alcalá, Díaz Cayeros, and Sánchez Reyes, "Solemne procesión a la imagen de Nuestra Señora de Loreto," 39 .
} 


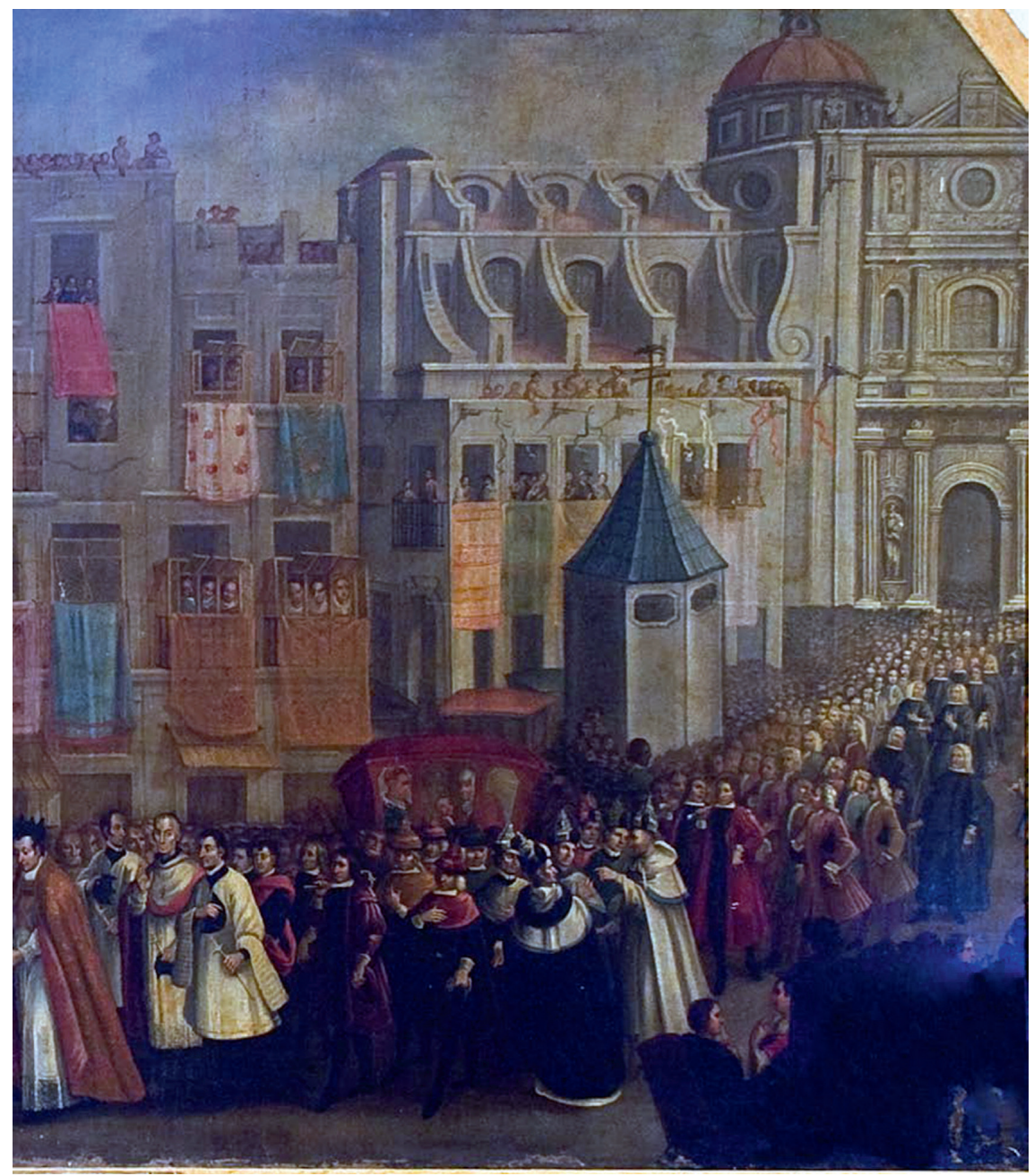

FIGURE 6 The 1727 procession staged in Mexico City with the statue of the Virgin of Loreto

and Corrientes counted 1,80o people in $1755 .{ }^{17}$ To put these population figures into context, in 1768, one year after the Jesuit expulsion, the population of the most populous of the missions among the Guaraní, Los Reyes Yapeyú, totaled 8,510 . In 1755, only one of the thirty missions among the Guaraní had a population smaller than that of Corrientes. ${ }^{18}$

17 Jeffrey Erbig, Where Caciques and Mapmakers Meet:Border Making in Eighteenth-Century South America (Chapel Hill: University of North Carolina Press, 2020), 16.

18 For the population, see Robert H. Jackson, A Population History of the Missions of the Jesuit Province of Paraquaria (Newcastle upon Tyne: Cambridge Scholars Publishing, 2019), 207-10. 
One colegio máximo and novitiate was located in the interior city of Córdoba, and it was here that the Jesuits organized the province in 16o7. The 1730-34 carta anua notes that the colegio máximo and novitiate had a staff of twenty priests, twenty-six brothers, and forty students. Two priests managed the congregaciones, which were similar to confraternities and provided a structure for the members to engage in collective acts of religious devotion such as rounds of prayers.

However, the main activity was educational. The schools had a staff of eight teachers. In the primary and secondary school, the main subjects were Latin and rhetoric. The subjects taught at university level included the theologies of Scholasticism and morality, canon law, the sacred writings, grammar, rhetoric, and Aristotelian philosophy. The novitiate had forty-eight novices, most of whom were from Europe, and four priests who had already taken the first three vows. They most likely were destined to serve in the colegios and particularly the missions in the province. ${ }^{19}$ There was also a colegio convictorio or boarding school with more than forty students, ${ }^{20}$ the Colegio de Nuestra Señora de Monserrat, which was established in 1687.

The Jesuits supported their operations in Córdoba, in part, from the fees they charged for the students in the primary and secondary schools. They also operated several estancias or agro-industrial complexes in the region, including that of Alta Gracia. ${ }^{21}$ The carta anua noted that construction of the main complex on the estancia was nearing completion. However, things did not always go so smoothly in the agro-industrial complexes. In 1731, for example, there were poor harvests followed by an epidemic that reportedly killed twenty-eight of the black slaves the Jesuits employed on the estancia and left the other slaves so ill that they could not work. Yet after the Jesuits organized a novena, the rains reportedly returned. ${ }^{22}$

Buenos Aires was the primary port city in the region and the seat of the civil government, first of the governor and later the viceroy when the crown created the viceroyalty of the Río de la Plata in the 1770s. The Jesuit installation there was also a colegio máximo at the time of the Jesuit expulsion. In the early 173 os (see fig. 7), twelve priests staffed the colegio in Buenos Aires, and there was also a casa de ejercicios that catered to laypeople who studied the Ignatian Exercises, with installations separated by gender. The casa was one

19 María Laura Salinas and Julio Folkenand, eds., Cartas anuas de la provincia jesuítica del Paraguay 1714-1720, 1720-1730, 1730-1735, 1735-1743, 1750-1756, 1756-1762 (Asunción: Centro de Estudios Antropológicos de la Universidad Católica, 2017), 203, 221.

$20 \quad$ Salinas and Folkenand, Cartas anuas de la provincia jesuítica, 223.

21 For a detailed study of the estancia of Alta Gracia, see Carlos Page, La estancia jesuítica de Alta Gracia (Córdoba: Universidad Católica de Córdoba, 2000).

Salinas and Folkenand, Cartas anuas de la provincia jesuitica, 221. 


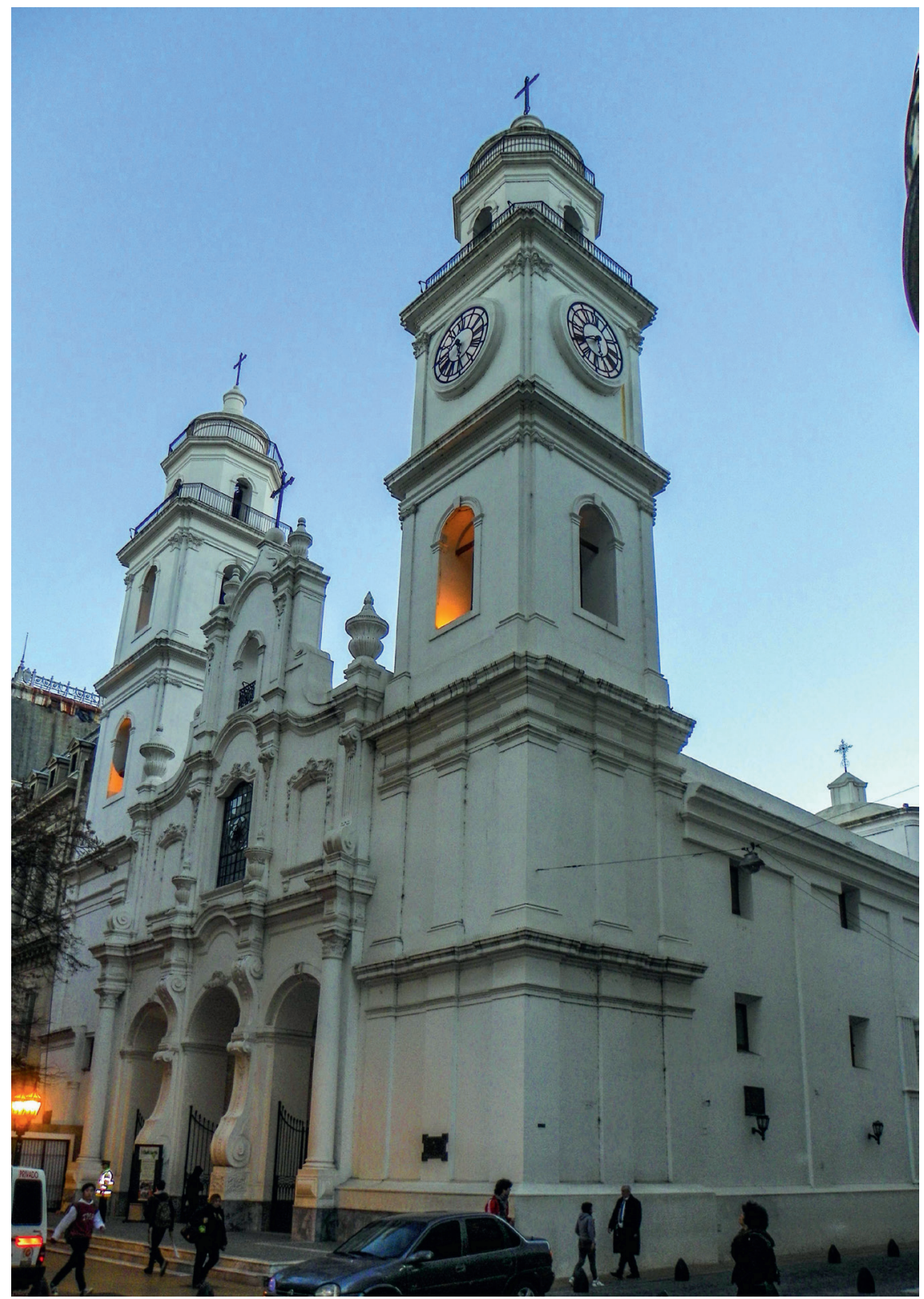

FIGURE 7 San Ignacio church in Buenos Aires 
of the major forms of outreach to the lay population of the city. In the 1730s, Governor Bruno de Zavala (1682-1736, in office 1717-35) recognized the importance of the Spiritual Exercises the Jesuits offered and authorized the soldiers in the city garrison to attend. ${ }^{23}$

The Jesuits had a large complex built in Buenos Aires, most of which no longer exists. San Ignacio church is still a functioning parish, and behind the church is a small complex that was the procuraduría or office that handled Jesuit financial transactions.

In addition to the income received from their estancias and other operations, the Jesuits in Buenos Aires received pious donations. In the early 173os, for example, one Ignacio Zevallos made a large donation for the construction of a new building in the Buenos Aires complex. Zevallos was a former Jesuit who had been stationed in Chile but later left the order for reasons that the author of the carta anua considered legitimate, most likely to manage the family business. Zevallos made an initial donation of fourteen thousand pesos and black slaves, and promised an additional future donation of another twenty thousand pesos. ${ }^{24}$

In the 1720 and 1730 s, the Jesuit presence in Asunción was problematic due to the ongoing civil-political unrest among the residents of the city known as the Comunero Uprising and the strong anti-Jesuit sentiment in the city. ${ }^{25}$ In 1724, the city's leaders ordered the Jesuits expelled, and in response Zavala mobilized the mission militia. The Jesuits and Guaraní mission leaders first organized and then institutionalized the militia in the 1630 os and $1640 \mathrm{O}$ in response to raids by Portuguese colonists from Brazil. The militia provided the bulk of the manpower for Spanish military campaigns during the seventeenth and eighteenth centuries. The militia engaged the rebels near the Tebicuarí River, but some three hundred Guaraní militiamen died in the battle. The viceroy in Lima ordered the return of the Jesuits to Asunción in 1728, but the leaders of the city ordered their expulsion once again on February 19, 1732, and armed guards escorted the Black Robes to the Tebicuarí River. ${ }^{26}$ As a consequence of the escalation of the conflict, Zavala ordered the mobilization of militia including thousands of mission militia. Zavala defeated the comuneros in battle in 1735, and once again the Jesuits returned to Asunción.

\footnotetext{
23 Salinas and Folkenand, Cartas anuas de la provincia jesuítica, 235-36, 238, 245.

24 Salinas and Folkenand, Cartas anuas de la provincia jesuítica, 246-47.

25 For a general discussion of the Comunero Uprising in Paraguay, see Mercedes Avellaneda, Guaraníes, criollos y jesuitas: Luchas de poder en las revoluciones Comuneras del Paraguay; Siglos XVII y XVIII (Asunción: Editorial Tiempo de Historia, 2014).

26 Salinas and Folkenand, Cartas anuas de la provincia jesuítica, 223.
} 
The cartas anuas provide different levels of detail on the other colegios in Paraquaria. The one in Corrientes had eight priests. That of La Rioja had a staff of six priests and three brothers and was heavily in debt. In 1733, hail damaged the crops, and the anua reported poor harvests in the region in the following year. However, the agricultural production on the properties of the colegio did not suffer. The colegio in Tucumán had a staff of seven priests and two brothers. This colegio and that of Santa Fe were located on the Chaco frontier and were exposed to raids by non-sedentary indigenous groups such as the Abipones and Mocovíes. In 1731 and 1734, priests from Tucumán served as military chaplains to expeditions sent against hostile indigenous groups. The anua did not report the number of Jesuits assigned to Santa Fe but did note the attacks by Abipones and Mocovíes. The military expeditions secured a peace in the mid-1730s after some twenty years of warfare, and beginning in the $1740 \mathrm{OS}$ the Jesuits began to establish missions among the groups of non-sedentary natives. In 1732, a fire largely destroyed the buildings of the colegio. The carta anua reported that nine priests lived on the colegio in Santiago Estero, which was a center of activity of missions among indigenous populations, and six on the colegio in Salta. There was also a colegio in Tarija located in what today is southern Bolivia. The staff of all the colegios attended to the spiritual needs of the urban populations and organized Ignatian Spiritual Exercises. ${ }^{27}$

One of the important activities of the urban colegios in Spanish America was what was called the "popular mission," that is, missions to the urban populations that were ostensibly already Catholic in order to correct doctrinal and other errors in the popular practice of the faith. As the author of the anua noted, to correct the "depraved customs" of the urban folk, the popular mission was as important as the Ignatian Exercises in making sure that they did not stray from the teachings of the church. ${ }^{28}$ The Jesuits also viewed this as a battle against Satan and his demonic minions. In the words of the author of the 1735-43 anua: "The exercises of Saint Ignatius were the powerful weapon with which, during these eight years our Fathers have battled our infernal enemies." ${ }^{29}$ One typical example was the popular mission organized from the colegio máximo in Buenos Aires in the early 1730 s to a group of Canary Islanders settled near Montevideo (modern Uruguay) in $1729 .{ }^{30}$ The colegios

27 Salinas and Folkenand, Cartas anuas de la provincia jesuítica, 226, 228, 231-32, 250, 255-59, 264,265 .

28 The Franciscans also organized popular missions in Spanish America. See, for example, David Rex Galindo, To Sin No More: Franciscans and Conversion in the Hispanic World 1683-1830 (Stanford, CA: Stanford University Press, 2017), 169-232.

29 Galindo, To Sin No More, 35 o.

30 Galindo, To Sin No More, 246-47. 
also organized popular missions to evangelize the rural populations, which, in the eyes of the Jesuits, were equally or more ignorant of doctrine. ${ }^{31}$ The Jesuits reinforced the teachings of the popular missions through the congregaciones, which were mostly dedicated to the cult of the Virgin.

There were also instances of other types of urban missions. The Catalan Jesuit Pere Claver Corberó (1580-1654) (better known as Pedro Claver) developed a special urban mission in Cartagena (modern Colombia), which was an important port for the importation of African slaves into Nueva Granada. Claver dedicated his missionary efforts to the evangelization of slaves imported through Cartagena, where he died in 1654 having spent much of his adult life there. The church canonized him in 1888 , and the church of San Ignacio in Cartagena where he is buried was renamed in his honor. ${ }^{32}$

The Jesuit college in the mining center of Zacatecas in Mexico provides another example of the role and particularly the financing of a Jesuit urban colegio and the resources dedicated to the construction of churches. The Jesuits established the Colegio de la Purísima Concepción in 1589. The college received a donation of land in the city as a site for the installation, as well as alms paid in money. Within two weeks of its founding, 120 students had already been registered for the program in basic education. The Jesuits later added programs in grammar, rhetoric, and philosophy. In 1756 , they founded a second colegio and seminary named San Luis Gonzaga. The Jesuits also attended to the spiritual and physical needs of the people of the city and organized two congregaciones dedicated to the Annunciata and Our Lady of the Sorrows.

The Jesuits directed the construction of a large complex and church that still exists today. In 1616, they received a donation of eight thousand gold pesos for the construction of a church, the costs of which are detailed in a document dated February 1, 1625. One accounting noted an expenditure of six thousand pesos for the woodwork, two thousand pesos for the wood delivered for the project, two thousand pesos for the master masons and workers, and 1,250 pesos for fifty thousand bricks. The cost of the main altar was eight thousand pesos, the lead covering cost four thousand pesos, and metal for the main door cost five hundred pesos. These and other costs totaled 29,99o pesos. There was an additional cost of 27,450 pesos for white stone for the church and two loads of stone for the church entrance. The total enumerated cost was

31 Galindo, To Sin No More, 456.

32 Paola Vargas Arana, "Pedro Claver y la evangelización en Cartagena: Pilar del encuentro entre africanos y el Nuevo Mundo, siglo XVII," Fronteras de la historia 11 (2006): 293-328. 
57,440 pesos. ${ }^{33}$ The Jesuits had the church rebuilt between 1746 and 1749 (see fig. 8). The colegio itself consisted of two buildings constructed as two-story structures (see fig. 9). ${ }^{34}$

The Jesuits charged their students fees, but one of the main sources of income for their Zacatecas installations came from three haciendas. In 1616, the same elite Zacatecas family that gave the Jesuits eight thousand gold pesos for the construction of a church for the colegio also donated a hacienda named Cieneguillas located in the Teocaltiche Valley. At the time of the Jesuit expulsion, the hacienda produced grain and also had cattle and horses. Corn was the most important crop, with production totaling 10,180 fanegas (one fanega is equivalent to 2.6 bushels). Wheat production was 4,842 fanegas. The hacienda counted 2,887 head of cattle and 4,842 horses and measured 43,747 hectares. The colegio also received a donation of two other haciendas. One was Santa Rita de Tetillas, which was the largest Jesuit hacienda in Mexico. At the time of the expulsion, the property measured some 170,323 hectares. The hacienda produced a small amount of corn and had 7,321 horses but specialized in grazing sheep. The post-expulsion inventory recorded 103,801 sheep and goats. The third hacienda was San Joseph de Linares, which was smaller, measuring 3,891 hectares. It produced 602 fanegas of corn and 348 fanegas of wheat and had fifty-seven head of cattle and 310 horses at the time of the Jesuit expulsion. The three were valuable properties: at the time of the Jesuit expulsion, La Cieneguillas had a value of 388,477 pesos, Santa Rita a value of 281,368 pesos, and San Joseph a value of 75,663 pesos. In 1765 and 1766 , the three properties produced a combined net income of 11,375 and 34,292 pesos respectively. ${ }^{35}$

\subsection{Conclusions}

The Jesuits played an important dual role in Spanish American cities. One was educational. Jesuit colegios provided basic and advanced education and also operated novitiates for the young men who wanted to enter the order. The Jesuits also played an important role in the spiritual life of the urban population and through the popular missions engaged in the role of evangelizers correcting the doctrinal errors of urban and rural folk who were ostensibly Catholic Christians. The Jesuits also offered organized outlets for popular spirituality such as the congregaciones and casas de ejercicios, where laypeople could do

33 Marco Díaz, "El patronazgo en las iglesias de la Nueva España: Documentos sobre la Compañía de Jesús en Zacatecas en el siglo XVII," Anales del Instituto de Investigaciones Estéticas 13, no. 45 (1976): 97-105.

34 Emilia Recéndez Guerrero, Llegado de la Compañía de Jesús a un centro minero Zacatecas (1592-1767) (Zacatecas: Universidad Autónoma de Zacatecas, 2013), 34-41, 68.

35 Recéndez Guerrero, Legado de la Compañía de Jesús, 78-80, 135. 

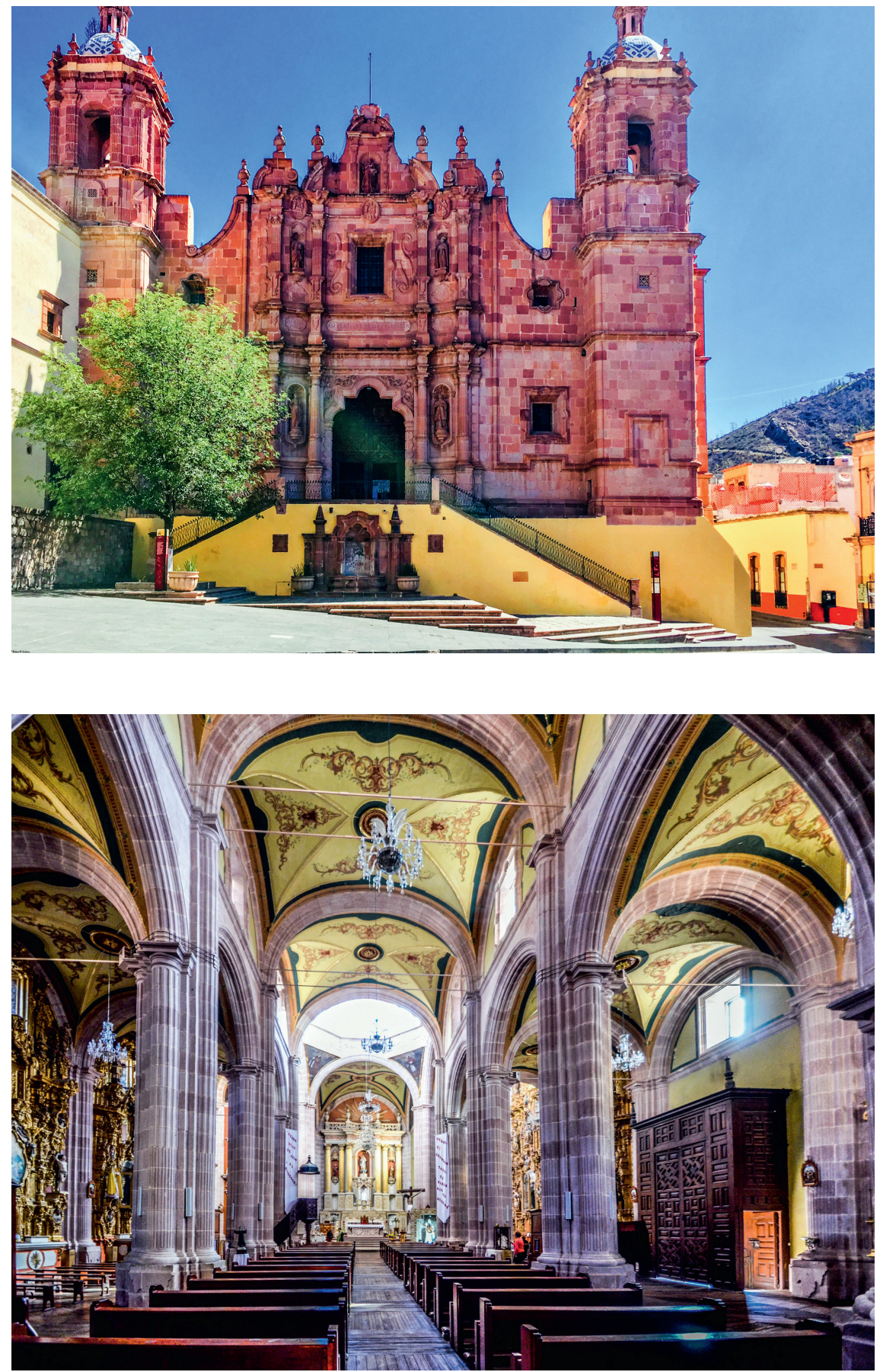

FIGURE 8 The church of the colegio of La Purisíma Concepción in Zacatecas 


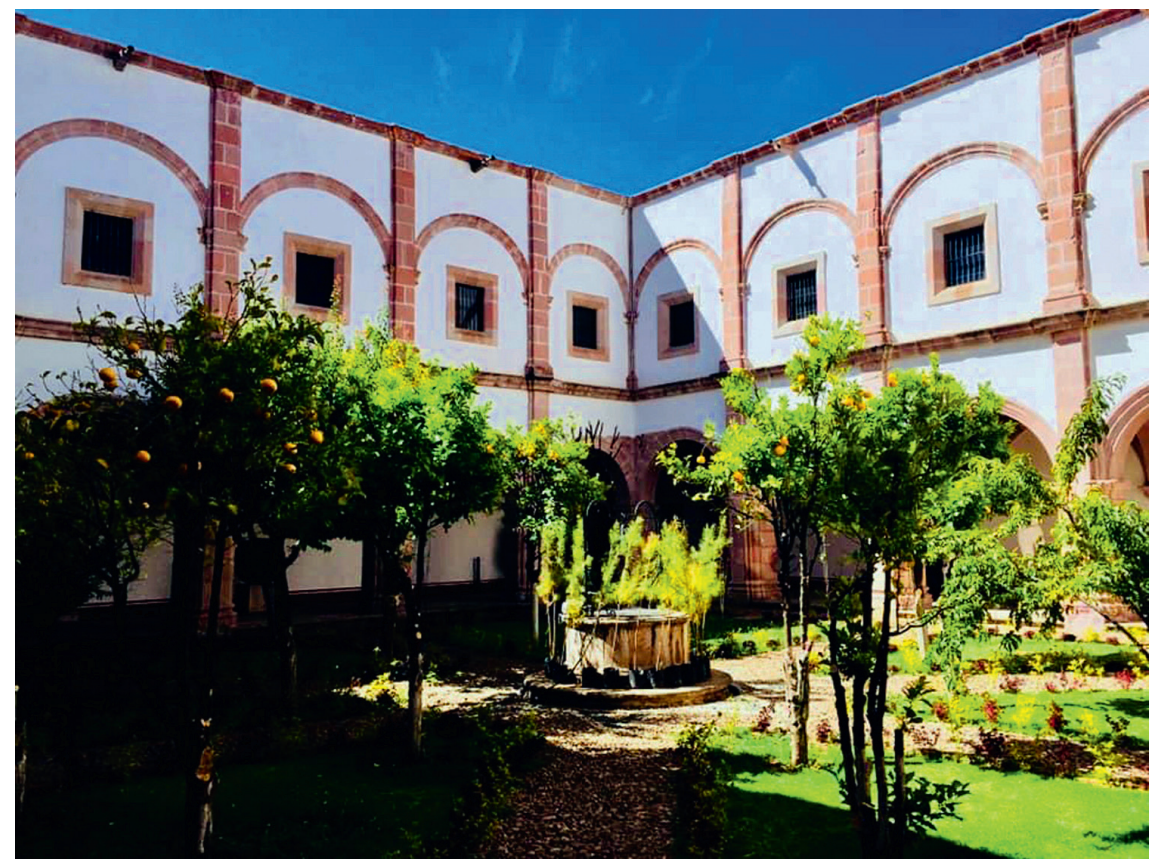

FIGURE 9 The main cloister of the colegio of La Purisíma Concepción in Zacatecas

the Ignatian Exercises. As major players in the spiritual life of urban populations, the Jesuits also helped people deal with the bad times. This section began with an example of a popular religious response to a serious measles epidemic in Mexico City in which the Jesuits organized and led a procession to seek divine relief from the contagion.

The Jesuits charged fees for education but also received pious donations of money and urban and rural property. The example of Zacatecas in Mexico was typical. The Jesuits received the donation of three valuable haciendas that generated income. The Jesuits in Zacatecas and other cities also owned urban properties. Moreover, a wealthy Zacatecas resident also donated money toward the construction of a church that proved to be costly. They invested considerable amounts in the construction of their urban installations such as the colegio in Zacatecas, or the Mexico City complexes discussed in section 2 such as the Colegio Máximo de San Pedro y San Pablo. The Jesuit church in Zacatecas cost nearly sixty thousand pesos in 1625 , with the main altar alone having a price tag of eight thousand pesos. The scale of these building complexes and churches was a testimony to the Jesuits' influence and economic power in the cities. 
In addition to their urban and educational role, the Jesuits staffed missions on the frontiers of Spanish America among sedentary and non-sedentary indigenous peoples, which was as or perhaps more important than their urban role given that it was the one instance where Jesuits supported royal policy in the Americas. This section presents the first case study of patterns of development, the Jesuit approach to evangelization, and the organization of the missions among the indigenous groups collectively known as the Guaraní. Voltaire's utopian fantasy and the other intellectual constructs that have described the Jesuit missions among the Guaraní present interpretations divorced from the historical context of the reality of Spanish royal objectives. It was royal policy to integrate indigenous peoples into colonial society as tribute payers, cheap labor, and consumers, and not as an economically dependent population. The Spanish created a system of indirect rule to govern the indigenous populations. In other words, indigenous community leaders were to govern the pueblos de indios, with the communities enjoying internal autonomy as long as they complied with the payment of tribute obligations and demands for labor. This system evolved in hierarchical state systems based on sedentary urban life in regions such as Tawantinsuyu in the Andean Highlands and in central Mexico. The missions were to engage in a process of social engineering and create pueblos de indios on the sedentary urban model where they did not exist and were to create new communities from whole cloth as in the case of the missions among the Guaraní.

The Spanish and Portuguese encountered clan-based agriculturalists that practiced shifting swidden agriculture and nomadic hunters and gatherers in the lowland region of South America that encompasses what today are parts of Argentina, southern Brazil, Uruguay, and Paraguay. This was a part of the region the Jesuits named the province of Paraquaria. The native groups inhabiting the region did not live in stratified and hierarchical states, so the Spanish devised other modes of colonization and exploitation. At the same time, Jesuit social engineering in the missions sought to convert them to a fully sedentary way of life. The Portuguese enslaved natives, whereas the Spanish used the encomienda (a grant of jurisdiction over a specific indigenous population with a right to collect tribute and demand labor services) to organize what amounted to forced labor. It was also a contested frontier, as the Spanish and Portuguese struggled over several centuries for control of land and native labor, even during the period of the Iberian Union (158o-1640). This conflict modified the development of the missions. 
The Franciscans were the first to attempt to evangelize the different native groups living in the region. The Jesuits entered the region in 1607, establishing the missionary province of Paraquaria in 1607. The initiative came from Jesuits stationed on the Jesuit colegio máximo in Cordoba already discussed in the previous section. Two years later, the missionaries established the first mission at San Ignacio Guazú, located in what today is southern Paraguay. The Jesuit strategy was to establish missions among Guaraní populations not held in encomienda and as far from Spanish settlement as possible. However, this also brought them close to the Portuguese settlements in southern Brazil. San Ignacio Guazú was a community partially held in encomienda, but the other missions established among the Guaraní were not. Over the next two decades, the Jesuits expanded to Guairá (modern Paraná State, Brazil), Tape (modern Rio Grande do Sul State, Brazil), Itatín (northern Paraguay), and what became the core territory located between the Paraná and Uruguay Rivers. Between 1610 and 1632, the Jesuits established and administered fifteen missions in Guairá: San Ignacio Miní (1610), Nuestra Señora de Loreto (1610), San Francisco Xavier (1624), San José (1625), Nuestra Señora de Encarnación (1625), Santa María (1626), San Pablo del Inaí (1627), San Antonio (1627), Los Ángeles (1627), San Pablo (1627), Nuestra Señora de Guananas (1627/28), Santo Tomás (1628), Emida de Nuestra Señora de Copacabana (1628), and Jesús María (1628). Luso-Brazilian frontiersmen and slave traders from Sao Paulo known as bandeirantes destroyed this group of missions in $1632 .{ }^{36}$

The Jesuit missions were located close to Portuguese settlements in southern Brazil. However, bandeirantes raided and forced the Jesuits to abandon Guairá and Tape in the 163os. Antônio Rapôso Tabares (1598-1658) led attacks on the Jesuit missions and Spanish settlements in Guairá that resulted in the abandonment of the thirteen missions located there and the first Jesuit retreat. ${ }^{37}$ According to one Spanish estimate, the Paulistas enslaved more than 150,00o Christian and non-Christian Guaraní in Guairá. ${ }^{38}$ In 1632, the Jesuits further retreated when they abandoned the Acaray and Iguaçu missions in

36 Claudia Parrellada, "El Paraná español: Ciudades y misiones jesuíticas en Guairá," in Missoes: Conquistando almas e territorios (Curitiba: Governo do Paraná, 2009), 130-41.

37 "Estado de las reducciones del Paraná y Uruguay y el fruto que por los religiosos de la Compañía de Jesús han conseguido sus avitadores," n.d. [c.1640], in Jaime Cortesão, Jesuitas e bandeirantes no Tape (1613-1641) (Rio de Janeiro: Biblioteca Nacional, 1969), 191-92.

38 "Copia del informe sobre la justificación con que los indios de las reducciones del Paraná y Uruguay [...] usan para su defensa de armas de fuego," in Cortesão, Jesuítas e bandeirantes, 315-26. 
Itatín in the face of the Paulista threat. ${ }^{39}$ The Jesuits relocated Santa María mission to a site near the west bank of the Uruguay River and renamed it Santa María la Mayor. In December 1636, Rapôso Tabares led a bandeira of some 140 Paulistas and 1,500 Tupí warriors against the Jesuit missions in Tape located in what today is Rio Grande do Sul, Brazil. On December 2, 1636, the Paulista-Tupí force attacked Jesús María, the mission located closest to the frontier as it existed at that time. ${ }^{40}$ The Paulistas then attacked and destroyed the missions of San Cristóbal, Santa Ana, and la Natividad. The Jesuits raised a force of 1,500 Guaraní warriors to defend the missions and confront the Paulistas, but the Black Robes also decided to evacuate the other missions, such as Candelaria, Los Santos Mártires, San Carlos, Apóstoles, and Santos Cosme y Damián, to new sites west of the Uruguay River. ${ }^{41}$ One Spanish source estimated that the Paulistas enslaved more than forty thousand Christian and non-Christian Guaraní during the invasion of Tape. ${ }^{42}$

During the period of the mission frontier's expansion between 1610 and the abandonment of Tape, the Jesuits congregated adults and children on the newly established mission communities and sought to convert them to Catholicism. The early cartas anuas describe the techniques used in teaching the new faith and what the Jesuits considered to be a "good Christian." The 1632 carta anua written by Pedro Romero (1585-1645), for example, describes the religious conversion of the Guaraní. ${ }^{43}$ According to the report, the doctrina of Los Santos Mártires del Caaró was still an active congregation, which meant that the Jesuits continued to settle and baptize pagan Guaraní on the mission during what was the initial stage of evangelization. The author reported that the resident missionaries had baptized $88 \mathrm{o}$ adults and 343 infants during the year. ${ }^{44}$ The report also noted that "knowing how to pray the prayers that the holy church uses is the sign of true Christians" and further elaborated on the method used to teach prayers: "They bring together all the young and old and the father makes them pray four or five times until they know the Ave Maria and the other prayers

39 Pedro Romero, May 16, 1632, "Estado General de las doctrinas del Paraná y Uruguay," in Cortesão, Jesuitas e bandeirantes, $46-56$.

40 Diego de Boroa, Corpus Christi, March 4, 1637, in Cortesão, Jesuitas e bandeirantes, 142-48; Diego de Boroa, Santa Fe, April 10, 1637, "De la entrada de los de S. Pablo en las red[uccion] es del Uruguay," in Cortesão, Jesuitas e bandeirantes, 153-61.

Diego de Boroa, Santa Fe, April 10, 1637, "De la entrada de los de S. Pablo en las red[uccion] es del Uruguay," in Cortesão, Jesuítas e bandeirantes, 146, 158, 217, 219, 223-24.

42 "Copia del informe."

43 Pedro Romero, May 16, 1632, "Estado General de las doctrinas del Paraná y Uruguay," 33-95.

44 Pedro Romero, May 16, 1632, "Estado General de las doctrinas del Paraná y Uruguay," 7o. 
well."45 A second indicator was the number of Christian marriages performed and the abandonment of traditional marriages and particularly the practice of polygamy, which the Jesuits characterized as concubinage. The report noted that the missionaries had performed four hundred marriages at Los Santos Mártires during the year. ${ }^{46}$ The 1634 report noted that the Black Robes baptized $5^{20}$ adults and 230 infants and performed 250 marriages. At the same time, a lethal epidemic stuck the mission, and the Jesuits reported that they buried 150 adults and 150 children. ${ }^{47}$

The Jesuits reported other examples of what they believed to be Guaraní compliance with the tenants of the new faith. As was the case with other missionaries, such as those in central Mexico in the sixteenth century, the Jesuits believed they were at war with the demon to win the souls of the indigenous population. Dreams were important in Guaraní beliefs, and the Jesuits commented on how they used dreams to pressure change "and at times with terrible dreams of demons in some detail, which has served to make many and very good confessions with corrections to their lives and customs." ${ }^{38}$ In explaining resistance to the new faith at Los Santos Mártires, the 1634 report claimed that the Guaraní had "turned their back [on the new faith], that without doubt the demon deceived them and took them far where he could take them for himself." ${ }^{49}$ The Guaraní attended Mass, confessed, and received Communion. The report emphasized attendance at special feast days and the rites associated with Lent and Easter, including penitential processions that included the practice of self-flagellation. ${ }^{50}$ However, the 1632 anua also reports other details that showed the persistence of traditional practices and beliefs. One is a description of the blessing of the first stake for the first church built at San Nicolás del Piratini, which occurred during Lent. The presiding missionary held a solemn Mass in which he explained why churches were built, yet the anua reported that the Guaraní blessed the first stake in their "bizarre" way, which included music and dances. The Guaraní clan chiefs (tuvicha) brought 150 gourds of chichi (corn beer) for the workers, and after finishing the project "they drank as was their practice with great reverie and happiness." ${ }^{11}$ While trying to place the act of raising the church at San Nicolás in the trappings of

\footnotetext{
45 Pedro Romero, May 16, 1632, "Estado General de las doctrinas del Paraná y Uruguay," 71-72.

46 Pedro Romero, May 16, 1632, "Estado General de las doctrinas del Paraná y Uruguay," 75.

47 "Letras annuas [...] 1634," in Helio Vianna, Jesuitas e bandeirantes no Uruguai (1611-1758) (Rio de Janeiro: Biblioteca Nacional, 1951), 11-113, here 108.

48 Romero, "Estado General de las doctrinas del Paraná y Uruguay," 41.

49 "Letras annuas [...] 1634," 109.

$50 \quad$ Romero, "Estado General de las doctrinas del Paraná y Uruguay," 43, 57.

51 Romero, "Estado General de las doctrinas del Paraná y Uruguay," 58.
} 
Catholic ritual and practice, what Romero described was an example of the Guaraní practice of communal labor on projects such as the construction of communal longhouses.

The report stresses the devotion of the Guaraní to Catholic ritual and practices. However, some practices such as penitential processions were a hard sell. In the $163^{2}$ апиа, Romero noted that the Guaraní initially "laughed at these things when we told them it was necessary to be penitent for their sins and to whip themselves so that God would pardon them." ${ }^{52}$ A second anua prepared around 1640 describes a penitential procession staged at San Nicolás del Piratini. ${ }^{53}$ Guaraní participants engaged in self-flagellation, the practice they had previously rejected. However, the context was important, as the anua described heavy epidemic mortality at a number of the missions, including at San Nicolás. Thus it would seem that the Jesuits successfully convinced some Guaraní that penitence was the appropriate response in the face of epidemic outbreaks. This was probably possible given that epidemics of Old World "crowd" diseases such as smallpox and measles were a new phenomenon that the Guaraní had not previously experienced.

At the same time, there were numerous examples of missionaries on different frontiers having to deal with traditional religious leaders using epidemics to attack the missionaries. The same anua reports a 1635 incident involving a Guaraní shaman who practiced just outside San Francisco Xavier mission. The shaman named Chemombe came to San Francisco Xavier, and his supporters erected a residence for him just outside of the mission where they consulted with him and participated in feasts and ritual dancing. Chemombe called for a return to the traditional way of life and particularly the practice of polygamy. He also called for the murder of Jesuit missionary Francisco de Céspedes (real name: Francisco Broglia [1599-1647]). A Guaraní loyal to the Jesuits warned the missionary, but he was still attacked and left for dead. The Jesuit made it to the nearby Los Santos Mártires mission. Chemombe and his followers fled to the mountains but were followed and captured by loyal Guaraní.

The Jesuits relied heavily on the support of clan chiefs to persuade the Guaraní to adopt the new faith. The 1634 report on Los Santos Mártires, for example, describes the support the missionaries received from Andrés Aretumba (dates unknown), who was one of the principal clan chiefs at the mission. According to the report, Aretumba

$52 \quad$ Romero, "Estado General de las doctrinas del Paraná y Uruguay," 57.

53 "Estado de las reducciones del Paraná y Uruguay," 178. 
helped the fathers a great deal to reduce [congregate or settle on the mission] the Indians, and also spoke to the people of the reductions [missions] of los Apóstoles and S[an] Carlos so that they would reduce [settle on the missions] and hear the words of the fathers, and we can say that with his help they made [formed] those two reductions [mission]. ${ }^{54}$

Aretumba reportedly embraced Catholicism and had a considerable influence on the mission residents. The report notes that when he died, the missionaries "had his burial with considerable solemnity and said some Masses because of the good heart [spirit] of the Indian and for everything he had helped us."55 As already noted, however, other clan chiefs continued to support traditional beliefs and resisted the early stages of the Jesuit mission program.

A difficult issue to resolve is the question of religious conversion, which was one of the central objectives of the Jesuit missionaries. The Jesuits reported what they considered to be evidence of conversion, such as the recitation of prayers learned through rote memorization, attendance at Mass, and compliance with the sacraments. Communion that followed confession was one of the sacraments the Jesuits recorded in the general censuses they prepared annually, in addition to the number of baptisms, marriages, and burials. The Jesuits assumed that the administration of Communion reflected an advanced understanding of and compliance with the tenets of Catholic doctrine and reported on the number of Communions administered in the first decades following the establishment of the missions. The 1634 report on Los Santos Mártires notes that many Guaraní confessed and received Communion. ${ }^{56} \mathrm{~A}$ 1661 report indicates that the Jesuits had confessed six thousand at Los Santos Mártires and that 3,500 had received Communion. ${ }^{57}$ One form of evidence of conversion is the 1801 ordination as a Catholic priest of a Guaraní who had attended seminary. Yet, at the same time, evidence also shows the persistence of a bone cult, shamanism, and the inclusion of traditional symbols in the churches built on the missions. ${ }^{58}$

In response to the Paulista raids, the Jesuits organized what would eventually become an institutionalized and formal military system on the missions. In 1640, Spanish royal officials debated the provision of firearms to the

\footnotetext{
54 "Letras annuas [...] 1634," 110-11.

55 "Letras annuas [...] 1634," 111.

56 "Letras annuas de las reducciones del Paraná y Uruguay del año de 1634," in Vianna, Jesuítas e bandeirantes, 108-13.

57 "Estado de las reducciones del Paraná y Uruguay del año de 1661," in Vianna, Jesuítas e bandeirantes, 200.

$5^{8}$ Jackson, Missions and the Frontiers, 242.
} 
Guaraní to defend themselves and the frontier from further Paulista attacks. ${ }^{59}$ The Spanish generally did not provide firearms to indigenous peoples because they feared that their subjects might use them on the Spanish themselves. The decision to allow the Guaraní to bear firearms, however, proved critical for the future development of the Spanish in the Río de la Plata region and the institutionalization of the mission militia.

In 1641, emboldened by the successful reassertion of Portuguese independence and the conquest of Guairá and Tape, a new bandeira left São Paulo to attack the surviving Uruguay missions. The Jesuits mobilized a force of two thousand Guaraní to confront the Paulistas, including some armed with firearms. The three-day Battle of Mbororé (March 9-11, 1641) was fought on the Uruguay River and on land near la Asunción del Acaraguá mission (La Cruz), which served as the center of operations. On the third day of the battle, the Paulistas sent a letter asking for a truce, but the Guaraní military leaders destroyed the letter and instead pursued and killed most of the Portuguese and Tupí warriors. ${ }^{60}$

In the battle's aftermath, the Jesuits institutionalized the mission militia. In 1647 , there was a total of 609 firearms distributed among most of the missions. The missions received another 150 in 1649 per a royal decree of September 20, $1649 .{ }^{61}$ The Jesuits included an armory in the mission urban plan where the weapons for the militia were stored. Royal officials periodically inspected the armory and enumerated the number and type of weapons. A 1716 inspection of Santa Rosa de Lima mission notes that the militia had twenty-three shotguns, ball and powder, lances, bows and arrows, and battle clubs. ${ }^{62}$ Royal officials came to depend on the mission militia for regional defense and mobilized it on many occasions for campaigns against the Portuguese, rebellious colonists in Paraguay, and hostile indigenous groups.

Following the Battle of Mbororé, the Jesuits focused their evangelization campaign on the region located between the Paraná and Uruguay Rivers. The Jesuits did establish other missions in the late seventeenth and early eighteenth century, but they did so by relocating Guaraní from existing missions. This occurred, for example, in the case of Santa Rosa de Lima mission, which

\footnotetext{
59 Jackson, Missions and the Frontiers, 242.

6o Claudio Ruyer, San Nicolás, April 6, 1641, "Relacion de la guerra q[ue] tubieron los Yndios contra los Portugueses de Brasil," in Vianna, Jesuitas e bandeirantes, 345-54.

61 "Relación simple de las armas de fuego q[ue] hallo en las reducciones del Paraná y Uruguay el Gov[ernad]or D[on] Jacinto de Laris," in Vianna, Jesuitas e bandeirantes, 437-39.

62 Carlos Page, La reducción jesuítica de Santa Rosa y su Capilla de Loreto (Asunción del Paraguay: Fotosíntesis editora, 2015), 11.
} 
the Jesuits established in 1698 at a site close to San Ignacio Guazú in what today is southern Paraguay with natives originally from the Itatín region northeast of Asunción who resided at Nuestra Señora la Fe mission. ${ }^{63}$ The population of Santa Rosa grew robustly in the first three decades of the eighteenth century due to high birth rates, and the vital rates were typical of the Paraguay missions, which were high fertility and high mortality populations. Death rates were high, but in non-epidemic years birth rates were higher. In 1702, four years after the mission had been established, 2,879 natives lived at Santa Rosa, a number that increased to 6,093 in 1731, making Santa Rosa one of the most populous of the Paraguay missions.

Following the establishment by the Portuguese of Colonia do Sacramento in what today is modern Uruguay in 1680, the Jesuits transferred several existing missions and established new communities in the region east of the Uruguay River to assert Spanish claims to the disputed borderland in the Banda Oriental (modern Uruguay). ${ }^{64}$ The Jesuits relocated San Nicolás and San Miguel missions east of the river, elevated San Francisco de Borja to the status of an independent mission, and established four new missions: San Luis Gonzaga, San Lorenzo Mártir, San Juan Bautista, and Santo Ángel Custodio with populations from existing missions.

Unlike earlier missionaries in central Mexico and the Andean region, the Jesuits implemented a policy of congregating the entire Guaraní population of a given mission on the newly created community. The Jesuit congregation of Juli in what today is Peru was one precursor to the urban organization of later missions in the Río de la Plata. ${ }^{65}$ Large numbers of people lived in small,

63 Ernesto Maeder, Una aproximación a las misiones guaraníticas (Buenos Aires: Universidad Católica Argentina, 1996), 5 o.

64 On the expansion of the Paraguay mission frontier into the Banda Oriental after 168o, see Robert H. Jackson, "Patrones demográficos de una frontera en conflicto: Las siete misiones orientales de la provincia jesuítica de Paraguay, 1680-1830," unpublished paper presented at the Seminário Internacional: Indígenas, Misionários e Espanhois o Paraná no contexto da Bacia do Prata, séculos XVI e XVII, Paraná, October 15-17, 2008.

65 See, for example, Marie Helmar, "Juli, un experimento misionero de los jesuitas en el altiplano andino (siglo XVI)," Boletín IRA 12 (1983): 191-216; Alexandre Coello de la Rosa, "La doctrina de Juli a debate (1575-1585)," Revista de estudios extremeños 63, no. 2 (2007): 95189; Ramón Gutiérrez, "Propuestas urbanísticas de los sistemas misionales de los jesuitas," in Un reino en la frontera: Las misiones jesuitas en la América colonial, ed. Sandra Negro Tua and Manuel María Marzal (Quito: Abya Yala, 20oo), 173-83; Armando Nieto Velez, S.J., "Jesuitas en el mundo andino: Las reducciones de Juli," Revista peruana de historia eclesiástica 2 (1994): 129-44; Ximena Malaga Sabogal, "Juli, la Roma de América: Memoria, construcción y percepciones del pasado jesuita en un pueblo del altiplano" (thesis for the licenciate, Pontificia Universidad Católica del Perú, 2011); Pablo Ruiz Martínez-Cañavate, "Ciudad y territorio en las misiones jesuíticas de indios guaraníes," in La Compañía de 
crowded apartments in a compact village, which facilitated the spread of contagion. The Jesuits commonly practiced quarantine by removing the sick and those exposed from the general population to temporary plague hospitals.

A second important element, particularly during the early phase of expansion to Itatín, Guairá, and Tape, was the danger of attack by Paulistas. The early mission sites such as those in Guairá contained defensive elements. For example, the Jesuits placed the San Ignacio mission between two rivers for defense. Archaeological excavations have documented the mission's urban plan, which included a defensive wall surrounding the complex, an element that was absent in later mission complexes. ${ }^{66}$ The Jesuits later relocated San Ignacio to a site on the Paraná River following its destruction in bandeirante attacks.

A diagram from around 1750 depicts the fully developed mission complex at San Miguel, which was typical of the missions in the eighteenth century (see fig. 10). The plaza was the space at the center of the complex, which was dominated by a monumental baroque-style church. Adjoining the church was the colegio. Housing for the mission residents flanked the three sides of the plaza. Although thousands of people living together in a compact community was a factor in the spread of contagion, it also facilitated social control and the mobilization of labor. This marked a difference between the politics of the Jesuit missions compared with the sixteenth-century central Mexican and Andean doctrinas and the other missions the Jesuits administered.

Royal officials and the Jesuits themselves expected the Guaraní to contribute to the development of the mission economies, which were to be as selfsufficient as possible. How the Jesuits organized the mission economies is a subject that must also be understood within the context of the rights and obligations of indigenous populations in the Spanish colonial system. The indigenous populations were to pay tribute and provide cheap labor to colonial elites, while the missions were to pave the way for the imposition of this pattern on frontier communities. ${ }^{67}$

Jesús y las artes: Nuevas perspectivas de investigación, ed. María Isabel Alvaro Zamora and Javier Ibáñez Fernández (Zaragoza: Universidad de Zaragoza, 2014), 259-78; Pablo Ruiz Martínez Cañavate, "Reducciones jesuíticas del Paraguay: Territorio y urbanismo" (PhD diss., Universidad de Granada, 2017).

66 Igor Chmyz, "Pesquisas arqueológicas nas reduções jesuíticas do Paraná," Revista do Círculo de Estudos Bandeirantes: Curitiba 15 (2001): 39-58.

67 See, for example, Graham, Vanished Arcadia; Koebel and Graham, In Jesuit Land; Caraman, Lost Paradise; Nonneman, "On the Economics of the Socialist Theocracy," 119-42; Frederick Hale, "Literary and Cinematic Representations of Jesuit Missions to the Guaraní of Paraguay, with Special Reference to the Film and Novel of 1986, The Mission" (PhD diss., University of South Africa, 1997); Vijaya Venkataraman, "Fictional Missions': Representations of Jesuit Encounters in Paraguay," in St. Francis Xavier and 


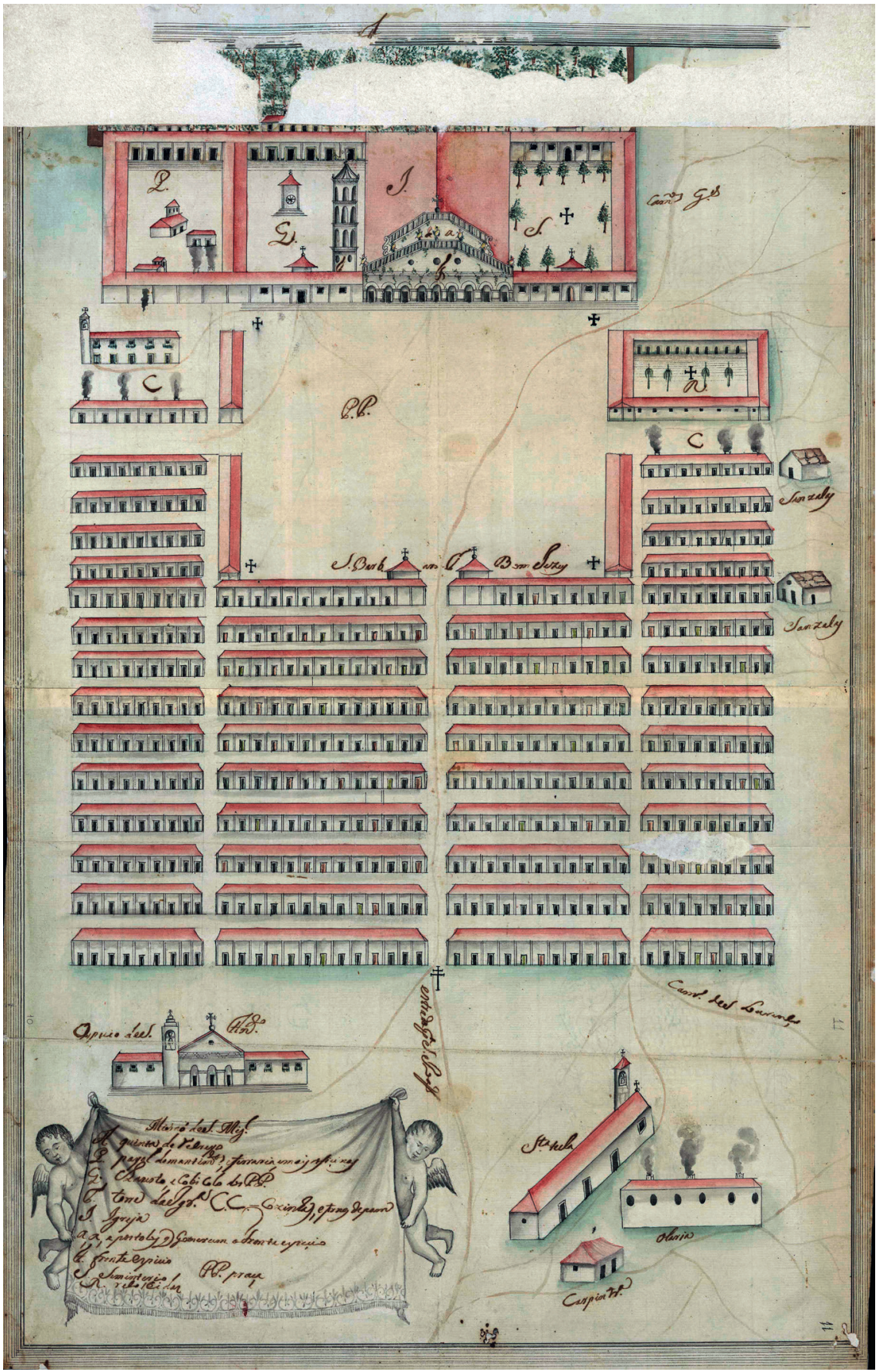

FIGURE 10 A c.1750 diagram of San Miguel mission showing the fully developed urban plan 
Existing research has documented the Jesuit practice of using communal production to pay the tribute obligations of the Guaraní residents of the missions, which was related to the Jesuit policy of establishing missions among Guaraní not encumbered by obligations to the holders of private encomiendas. During periods of crisis, as in the 173 os and again in the 175 os during the uprising in the eastern missions following the implementation of the Treaty of Madrid (1750), the Jesuits were unable to meet the complete tribute payments. In the years $1728-34$, the Jesuits paid 66,701 pesos per year into the Buenos Aires treasury, a figure that dropped to 28,420 in $1734-36,28,649$ in $1736-39$, 28,443 in $1739-42$, and 18,88 o in $1742-44$. In 1735 , in the midst of the crisis, royal officials directed the Jesuits to prepare a new tribute census. Tribute payments increased to 79,992 in the years $1744-49,{ }^{68}$ but the uprising in the eastern missions of the mid-175os undermined the Jesuits' ability to pay, and payments consequently dropped to 12,081 pesos in $1758,14,381$ in 1761 , and only recovered to 57,524 in 1766 . The Jesuit expulsion also disrupted tribute payments, which dropped to a mere 560 in 1769 and 6,911 in 1770 but recovered again to forty thousand in $1772 .{ }^{69}$

In 1751, the superior provincial of the missions ordered the preparation of two detailed reports examining the tribute payments of the missions. ${ }^{70}$ Four missions located in what today is southern Paraguay, Guazú, La Fe, Santiago, and Santa Rosa, made tribute payments to the royal treasury office in Asunción. The bulk of the population of Guazú was held in encomienda and paid only a small amount to the royal treasury. Ytapúa paid to the treasury office in Santa Fe. The others paid to the treasury office in Buenos Aires. At the time of the report, the populations of the missions were continuing to recover from the mortality crises of the years $1733-40$ and followed patterns similar to those in the 173 os that had caused arrears in tribute payments. During the crisis years, the Jesuits complied with the orders of royal officials to mobilize thousands of mission militiamen and supply them with food. A second chronic problem was flight. Even before the onset of the crises, small numbers of Guaraní left the missions without permission and were classified as "fugitives." In 1735, royal

the Jesuit Missionary Enterprise: Assimilations between Cultures/San Francisco Javier y la empresa misionera jesuita: Asimilaciones entre culturas, ed. Ignacio Arellano and Carlos Mata Induráin (Pamplona: Servicio de Publicaciones de la Universidad de Navarra, 2012), 305-17.

68 Jackson, Missions and the Frontiers, 148-49.

69 Jackson, Missions and the Frontiers, 161.

70 "Apuntes sobre las cuentas de los tributes que se hizo el a[ñ $]$ o $175^{1}$ por orden del P[adr]e Prov[incia]l Manuel Guerini a fines de Agosto," cA; "Liquidación de los Tributos Synodos, quanto sea, adonde y como se pagan, y lo que van demás de otros pueblos," CA. 
officials ordered the preparation of a new tribute census, and the censuses recorded a growth in the number of "fugitives." The number of registered tributaries was 19,116, but 3,094 were absent, some sixteen percent of the total. ${ }^{71}$ This continued to be a problem at the time of the preparation of the 1751 report.

The 1751 report compared the number of tributaries on twenty-six of the missions as reported in the 1735 tribute censuses and in 1751. The addition of population figures places the number of tributaries into context. The 1735 tribute censuses recorded a total population of 111,122 . This number dropped to 95,649 at the end of $175^{\circ} .^{72}$ The 1751 report detailed twenty-six of the missions but did not include Guazú, La Fe, Santiago, and Santa Rosa. In 1735, the population of the twenty-six missions totaled 10o,949 and counted 17,556 tributaries, of which 2,412 reportedly were "fugitives," or fourteen percent of the total. The same twenty-six missions reportedly had a population of 82,114 at the end of 175 . The missions suffered population losses during the crises of the $1730 \mathrm{O}$ but at the same time had grown during the 1740s. The number of tributaries was 15,589 .

The Jesuits managed different economic enterprises to produce income to cover the costs of their educational activities in colonial cities and the missions, including tribute payments and the procurement of supplies such as wine not produced on the missions. As already noted, the Jesuits owned ranches located in northern Argentina and bred mules for sale in the mining centers of Upper Peru (Bolivia). ${ }^{73}$ Jesuit-owned estates in the coastal valleys of Peru produced wine and aguardiente (cane brandy) and employed African slave labor. ${ }^{74}$ The Jesuits stationed on the missions among the Guaraní sold yerba mate (local tea), textiles, and tobacco. In 1666, royal officials limited the amount of yerba mate that could be sold to twelve thousand arrobas or three hundred thousand pounds. ${ }^{75}$ The Jesuits sent teams of Guaraní to collect yerba mate in stands of wild trees known as yerbales but later developed plantation-style production. Some stands were located at some distance from the missions and in some

\footnotetext{
71 "Numeración extraordinaria que se saco de los Padrones Jurados del año de 1735," CA.

72 Jackson, Population History of the Jesuit Province of Paraquaria, 54, 208-9.

73 Nicholas Cushner, Jesuit Ranches and the Agricultural Development of Colonial Argentina, 1650-1767 (Albany, NY: SUNY Press, 1982).

74 Cushner, Lords of the Land.

75 Jackson, Missions and the Frontiers, 150-55; Julia Sarreal, The Guarani and Their Missions: A Socioeconomic History (Stanford, CA: Stanford University Press, 2014), 85-91. Sarreal (220-21) provides global figures of yerba mate and textile sales of twenty-nine of the missions excluding Yapeyú but does not provide a mission-by-mission breakdown. In the period from $173^{1}$ to 1745 , sales of yerba mate averaged 49,321 pesos and that of textiles 13,172 pesos; in the years 1770 to 1788 under civil administration it was 41,943 and 3,938 pesos respectively; and it declined in the years 1791 to 1806 to 6,517 and 793 pesos respectively.
} 
cases east of the Uruguay River and are depicted in contemporary maps. At the time of the Jesuit expulsion, for example, Santa Rosa owned thirty-eight thousand yerba mate trees, the largest number of all the missions, followed by Santos Cosme y Damián with twenty-five thousand. ${ }^{76}$

There are accounts in the Buenos Aires and Santa Fe oficio offices for the years $1731-45 \cdot{ }^{77}$ These years coincided with a multi-year drought, the mobilization of thousands of mission militia and the provision of food to the militiamen on campaign, the flight of thousands from the missions, and a series of severe epidemics that caused catastrophic mortality: some ninety thousand mission residents died between 1733 and 1740. There are also reports of the visitations of the provincials to each individual mission. The reports also record the debts of the mission economy administered by the Jesuits, the number of livestock, and in some instances the products the Jesuits sold. ${ }^{78}$ A 1731 report for San Carlos mission enumerates the quantity of the different products: iron, 2,500 arrobas (62,50o pounds) of yerba mate, two thousand arrobas (fifty thousand pounds) of cotton, 124 arrobas (3,100 pounds) of metal for casting bells, twenty-nine arrobas (725 pounds) of tobacco, eight arrobas (two hundred pounds) of wax, one and a half arrobas (37.5 pounds) of honey, 3,751 pounds of cloth, and nineteen hats. Other missions sold other products such as cotton thread, wool, and salt.

\subsection{Mission Demographic Patterns}

Demographic patterns are important for understanding the history of the missions. In the seventeenth century, the Jesuits created mission communities from whole cloth and congregated thousands of natives, both adults and children, on the new communities. The missions had open populations, which meant that the populations expanded through natural reproduction but also from the settlement of non-Christians. The Jesuits baptized adults and children alike. There are scattered reports in the cartas anuas of the 1620 s and 1630 of the baptisms and resettlement of non-Christians on the missions, with one Jesuit reporting that they had baptized 94,990 in Guairá between 1610 and 1626.79

76 Jackson, Missions and the Frontiers, 153 .

77 Sarreal, Guaraní and Their Missions, 85-91. Carbonell de Masy, Estrategias de desarrollo rural en los pueblos guaraníes (1609-1767) (Barcelona: Antoni Bosch Editor, 1992), published and analyzed the oficio accounts for each mission.

78 Sarreal consulted the reports for the same atypical crisis years. Reports for selected missions in 1728, 1730, and 1731, all pre-crisis years, are preserved in the AGN, Sala IX-9-9-6.

79 Jurandir Coronado Aguilar, Conquista espiritual: A história da evangelização na província Guairá na obra de Antonio Ruiz de Montoya, S.J. (1585-1652) (Rome: Editrice Pontificia Università Gregoriana, 2002), 213. 
TABLE 4 Baptisms and burials recorded at five missions from the date of foundation to 1648

\begin{tabular}{lrlr}
\hline Mission & $\begin{array}{l}\text { Baptisms over } \\
\text { age ten }\end{array}$ & $\begin{array}{l}\text { Baptisms of párvulos } \\
\text { (children under the age } \\
\text { of ten) }\end{array}$ & Burials \\
\hline Guazú & 877 & 2,588 & 1,772 \\
Candelaria & 2,833 & 2,828 & 3,767 \\
Santos Cosme y Damián & 1,965 & 2,403 & 2,184 \\
San Carlos & 3,615 & 3,503 & 4,158 \\
Santa Ana & 2,128 & 2,332 & 1,568 \\
Total & $\mathbf{1 1 , 4 1 8}$ & $\mathbf{1 3}, 654$ & $\mathbf{1 3 , 4 4 9}$ \\
\hline
\end{tabular}

SOURCE: INDIVIDUAL MISSION REPORTS 1648, CA.

The first attempt to quantify the number of baptisms was a series of reports prepared in October 1648 that summarized the number of baptisms and burials from the date of establishment of selected missions to the time of the drafting of the reports. The numbers came from the sacramental registers of baptisms and burials. ${ }^{80}$ The practice was to number each individual entry in the sacramental registers, but it was not rare for there to be errors in the sequence. As such, the numbers are not completely accurate. There are reports for five missions: San Ignacio Guazú, Candelaria, Santos Cosme y Damián, San Carlos, and Santa Ana (see table 4). Altogether, the Jesuits reported the baptisms of 11,418 "adults" (those roughly above the age of ten) and 13,654 young children, as well as 13,949 burials. In this way, the Jesuits rapidly expanded the populations of the newly established mission communities.

The populations of the missions passed through several phases during the seventeenth century. The first phase marked the expansion of the missions in the period $1610-36$ into several regions including Guairá, Tape, Itatín, and the Uruguay River area. This was followed by retreat as a consequence of the bandeirante raids of the 1620 s and 1630 s and ended with the Battle of Mbororé in 1641. The Jesuits relocated a number of the missions the bandeirantes destroyed to the area between the Paraná and Uruguay Rivers and reorganized their evangelization campaign. A 1705 report summarized the populations of

8o The reports are found in CA. 
TABLE 5 The total population of the Paraguay missions in selected years during the seventeenth century

\begin{tabular}{llll}
\hline Year & Number of missions & Total population & Mean population \\
\hline 1634 & 24 & 40,327 & 1,680 \\
1648 & 19 & 30,548 & 1,608 \\
1657 & 19 & 36,251 & 1,908 \\
1677 & 22 & 58,118 & 2,642 \\
1691 & 26 & 80,831 & 3,109
\end{tabular}

SOURCE: FRANCISCO BURGES, "FRANCISCO BURGES DE LA COMPAÑIA DE JESÚS, PROCURADOR DE LA PROVINCIA DE PARAGUAY,” N.P.: N.D. [1705], ARCHIVO GENERAL DE LAS INDIAS, SEVILLA, SPAIN, CHARCAS 381.

the missions in selected years during the seventeenth century (see table 5$)^{81}$ In 1634 , the Jesuits administered twenty-four missions with a total population of 40,327. This included the missions in Tape, but not the Guairá communities that had already been abandoned two years earlier. This number dropped to 30,548 in nineteen missions following the abandonment of the Tape missions. The numbers slowly grew largely through natural reproduction over the following decades. A 1657 inspection tour of the missions left the first complete and existing population count and recorded the number of families, the number of tributaries, and total population. It reported a total population of 36,046 on nineteen missions. ${ }^{82}$ In 1677 , there were twenty-two missions with a population of 58,118 . The increase in the number of missions reflected the relocation of the two Itatín missions in 1659. In 1691, the missions had a population of 80,831 on twenty-six missions, an increase in the number of mission communities that resulted from the establishment of new missions and the relocation of existing ones to the region east of the Uruguay River.

As the missions matured, the populations became largely closed populations, which meant that there were not significant numbers of non-Christians resettled on the missions and growth occurred through natural reproduction.

$81 \quad$ Francisco Burges, "Francisco Burges de la Compañia de Jesús, procurador de la provincia de Paraguay," n.d. [1705], Archivo General de las Indias, Sevilla, Spain, Charcas 381.

82 "Breve summa y compendio de todos los indios, familias y personas de ambos sexos y todas edades que se hallaron en las dos provincias del Uruguay y Parana en la visita delas que nico por orden de su Mag. D. Ju[an] Blasquez de Velarde, Oydor de la R[ea]l aud[iencia] de la ciudad de la Plata, gov[ernado]r y cap[itan] g[enera]l de la prov[inci]a del Paraguay," CA. 
However, the Jesuits did periodically settle small numbers of non-Christians at the end of the seventeenth century and the early eighteenth. Table 6 summarizes the number of baptisms of adult non-Christians in selected years between 1690 and 1718 . The 1691 and 1702 censuses, for example, contain a column for baptisms of adults in which the Jesuits reported small numbers of baptisms of adults at several missions. In 1691, for example, the Jesuits baptized seven adults at Candelaria, eleven at Jesús, and ten at Jesús María de los Guenoas, which the Jesuits established in 1690 in an effort to congregate non-sedentary bands of Guenoa Minuanos from the Banda Oriental (modern Uruguay). There was a larger number in 1702 with two at Ytapúa, four at Jesús, one at San José, three at Santa Ana, ten at Loreto, seven at San Ignacio, and forty-six Guañanas that lived to the north in the territory between the Paraná and Uruguay Rivers at Corpus Christi. ${ }^{83}$ The Jesuits at Corpus Christi continued to congregate small numbers of Guañanas over the following decades. A detailed 1759 tribute census of Corpus Christi reported 112 that had been resettled on the mission in 1724, 1730, and 1754. They were organized politically into separate cacicazgos, but there was intermarriage with the Guaraní population of the mission. ${ }^{84}$ Jesús María mission located east of the Uruguay River was a special case. The Jesuits established the mission in 1690 for the Guenoa Minuanos and congregated numbers of non-Christians there during the life of the mission.

One element of Jesuit policy is what we can call "population politics" or the relocation of populations for different purposes including for geopolitical considerations in the disputed Río de la Plata borderlands due to the ongoing conflict between Spain and Portugal (see table 7). This was done, for example, to expand the mission frontier east of the Uruguay River beginning in 1687. The first example of this practice was the relocation of San Nicolás to a site east of the Uruguay River. San Nicolás and Apóstoles missions had shared the same site for some forty years following the relocation of San Nicolás from Tape. The reports listed the two missions together. In 1677, San Nicolás and Apóstoles had populations of 2,921 and 2,158 respectively. In 169o, following the relocation, San Nicolás had a population of 3,748 and Apóstoles 3,222. In the same year, the Jesuits also relocated the San Miguel mission.

The Jesuits established two other missions in 1687. The first was San Luis Gonzaga, with the new community being created by transferring 2,500 people from Concepción mission. Similarly, the Jesuits transferred some 2,300 people

\footnotetext{
83 "Annua numeracion de los Indios del Parana y Uruguay que están a cargo de Comp[añí]a de IEsus hecha al fin del año de 1691," ARSi; "Numero de las doctrinas, familias, almas, baptismos, y ministros del Parana/Uruguay del año de 1702," AG I.

84 Jackson, Demographic Change and Ethnic Survival, 101-2.
} 
TABLE 6 Baptisms of adult non-Christians on selected missions, in selected years

\begin{tabular}{|c|c|c|c|c|c|c|c|c|c|c|c|c|}
\hline Mission & 1690 & 1691 & 1693 & 1695 & 1698 & 1700 & 1702 & 1705 & 1707 & 1708 & 1717 & 1718 \\
\hline Jesús María & 21 & 10 & 14 & 31 & & 1 & & 23 & & 11 & & \\
\hline Candelaria & & 7 & & & & & & & & & & \\
\hline Jesús & & 11 & & 31 & & & 4 & & & & & \\
\hline Yapeyú & & & 1 & & 19 & & & & & & & \\
\hline Ytapúa & & & & & & & 2 & & & & & \\
\hline Concepción & & & & & & & & & 3 & & & \\
\hline San José & & & & & & & 1 & & & & & \\
\hline Santa Ana & & & & & & & 3 & & & & & \\
\hline Loreto & & & & & & & 10 & & & & & \\
\hline San Ignacio Miní & & & & & & & 7 & & & & & \\
\hline Corpus & & & & & & & 46 & & & & & \\
\hline $\begin{array}{l}\text { San Francisco } \\
\text { Xavier }\end{array}$ & & & & & & & & & & 18 & & \\
\hline $\begin{array}{l}\text { San Francisco } \\
\text { de Borja }\end{array}$ & 19 & 6 & 25 & 15 & 4 & & 33 & 19 & 2 & & & \\
\hline Santo Ángel & & & & & & & & & 5 & & 1 & 5 \\
\hline
\end{tabular}

SOURCE: ROBERT H. JACKSON, A POPULATION HISTORY OF THE MISSIONS OF THE JESUIT PROVINCE OF PARAQUARIA (NEWCASTLE UPON TYNE: CAMBRIDGE SCHOLARS PUBLISHING, 2019), 159.

TABLE 7 Transfers of population to establish new missions

\begin{tabular}{lll}
\hline Year & Source mission & Newly established mission \\
\hline 1682 & Santo Tomé & San Francisco de Borja \\
1687 & Apóstoles & San Nicolás \\
1687 & Concepción & San Luis Gonzaga \\
1690 & Santa María la Mayor & San Lorenzo \\
1697 & San Miguel & San Juan Bautista \\
1698 & Nuestra Señora la Fe & Santa Rosa \\
1706 & San Carlos & La Santísima Trinidad \\
1707 & Concepción & Santo Ángel Custodio \\
\hline
\end{tabular}

SOURCE: JACKSON, POPULATION HISTORY OF THE MISSIONS OF THE JESUIT PROVINCE OF PARAQUARIA, 160. 
from Santo Tomé to establish San Francisco de Borja located across the Uruguay River. The community already existed as a visita (a satellite community with no resident missionary). The Jesuits established three new missions in the 169os. The first was San Lorenzo in 169o. The Jesuits relocated some 3,500 people from Santa María la Mayor to San Lorenzo. The second new mission was San Juan Bautista, which was founded in 1697 with the transfer of some 2,80o people from San Miguel mission. The third example was Santa Rosa, which was founded in 1698 with the transfer of 2,6oo people from Nuestra Señora la Fe.

The Jesuits established two new missions in the first decade of the eighteenth century during the War of Spanish Succession (1701-13), a renewal of Spanish-Luso-Brazilian colonial rivalry under the guises of an international conflict in which Spain was allied with France and Portugal with England. The first of the new missions was la Santíssima Trinidad, which was established in 1706 to shore up the frontier. The Jesuits moved some 2,80o people from San Carlos to the new establishment. San Carlos counted a population of 5,212 in 1706 and 2,840 the following year. Trinidad had a population of 2,847 in 1707 . The second new mission was Santo Ángel Custodio, which was founded in the following year at a site east of the Uruguay River with some 2,900 people from Concepción mission. The total population of Concepción was 6,449 in 1706, which dropped to 3,334 in the following year. The 1707 census reported a population of 2,879 on Santo Ángel Custodio.

A second purpose of "population politics" was to increase the population of missions that had experienced heavy mortality and particularly epidemic mortality. There are two well-documented instances of this. The first occurred at Yapeyú mission following the severe 1718-19 smallpox epidemic. The mission population dropped by around a thousand from 2,873 in 1717 to 1,871 in 1719. In the aftermath of the epidemic, the Jesuits transferred the population from San Francisco Xavier mission to Yapeyú. This most likely took place in 1722, with the Jesuits relocating some 2,400 people. The population of Yapeyú increased from 1,871 in 1719 and 1,856 in 1720 to 4,352 in 1723 and 4,36o in 1724. The population of San Francisco Xavier, on the other hand, suffered light mortality during the epidemic. It numbered 5,6oo in 1717 and dropped to 5,352 in 1719 and 5,280 in 1720. It further dropped to 3,409 in 1724 following the population transfer. The Guaraní from San Francisco Xavier retained their separate identity in their own clans, which the Jesuits enumerated separately from the clans of the original population of Yapeyú..$^{85}$

85 An untitled and undated tribute census for Yapeyú, probably from 1759, divided the population between the original groups and those transferred from San Francisco Xavier. The tribute census is found in AGN, Sala 9-17-3-6. 
There was a second example of the relocation of population to a mission left with small numbers following an epidemic at Santa María la Mayor in 1745, which had experienced heavy population losses during the mortality crisis of the 1730 . In 1732, the numbers stood at 3,905 but then dropped to 711 in 1739, or a net decline of nearly 3,200 over seven years. A total of 1,279 alone died in 1739 during the smallpox outbreak of that year. The population did not show signs of recovery over the next several years. In 1744, the total population numbered 993 living in 267 families. This number must have been below the threshold that the Jesuits believed necessary for a viable mission community, as in 1745 they transferred some nine hundred people and 225 families to the mission, a figure calculated as the difference in the numbers reported at the end of 1745 less twenty-eight marriages recorded during the year. I have also adjusted the crude birth and death rates for 1745 to reflect the population transfer. The adjusted crude death rate per thousand population is 82 .o per thousand, and a crude death rate of 36.7 per thousand.

The combination of large populations living in spatially compact communities, rapid communication and the movement of people and goods via the navigable rivers in the region, and the movement of armies on campaign meant that epidemics spread quickly through the missions. Moreover, the high fertility rates meant that there was a large number of potentially susceptible people when contagion spread through the missions, generally the people born since the previous epidemic who had not been exposed to the maladies. In 1731 and 1732 , the populations of the Jesuit missions continued to grow, totaling more than 141 ,ooo.

However, it had been fourteen years since the last severe smallpox epidemic in 1718-19, and conditions were ripe for a series of severe mortality crises. Rapid population growth since the last epidemic also meant that there were a large number of potentially susceptible people on the missions, and in particular children born since the last outbreak who had not been previously exposed to contagion.

The severe mortality crises combined with the mobilization of thousands of militiamen, famine, and epidemics to reduce the size of the populations from a record high of 141,182 in 1732 to 73,910 at the end of 1740 . The Jesuits reported that they recorded 90,571 burials between 1733 and 1740. A combination of factors contributed to the heavy population losses. One was the mobilization of Guaraní militiamen for service in Buenos Aires, the Banda Oriental (Uruguay), and on the Tebicuarí River to confront the ongoing political crisis in Asunción known as the Comunero Uprising. ${ }^{86}$ The second was the high population 
densities of the mission communities and the large number of children and young adults born since the last major epidemic in 1718-19. The third was drought and famine conditions that contributed to large-scale flight from the missions as people left in search of food and to escape disease.

The last epidemic during the decade was identified as a smallpox outbreak that spread to the missions at the end of 1737 from Buenos Aires and other urban centers in the region. ${ }^{87}$ Elevated mortality at several missions indicates that the contagion may have broken out at the end of 1737. The location of the missions suggests that smallpox spread from Asunción. The death rate in Ytapúa was 104.1 per thousand population in 1737, but the epidemic continued into 1738 and perhaps flared up again at the beginning of 1739 . The total number of burials in the three years was 2,405 and the death rate 530.1. The crude death rates at Jesús and Trinidad were 184.2 and 154.1 per thousand population respectively. The epidemic then spread to more missions in 1738 . The crude death rate was greater than five hundred per thousand population at two missions, greater than four hundred per thousand population at another two missions, and greater than three hundred at two others (see table 8). In three years (1738-40), the Jesuits reportedly buried 35,104 people, with the population experiencing a net decline of 22,575.

The mortality crises of the 1730s and especially the smallpox epidemic exacted a heavy toll on the Guaraní. In the years 1733 and 1735-40, the Jesuits recorded a total of 34,763 baptisms and 75,269 burials, or a net decline of 40,506. Another 16,222 reportedly died in $1734 .{ }^{88}$ However, the populations eventually recovered. In the years 1741 and $1744-5$ o, the Jesuits recorded a total of 49,652 baptisms and 34,654 burials, or a net growth of $14,998 .{ }^{89}$ This resulted from the formation of new families following epidemics and increased birth rates. This can be seen at Santa Rosa and Ytapúa in 1733. In 1728, Santa Rosa had a population of 6,o64, and the Jesuits recorded fifty marriages. Marriages in 1733 totaled fifty-seven in a rapidly declining population and could have been higher were it not for the pattern of higher mortality among females resulting from immunological responses to maladies such as smallpox and measles. The

$87 \quad$ There was heavy mortality at several missions in 1737 , which indicates that smallpox broke out there at the end of the year. The crude death rate was 104.5 per thousand population in Ytapúa, 184.2 in Jesus, and 154.1 in Trinidad. The epidemic continued in Ytapúa into 1738. "Catalogo de la numeración annual de las doctrinas del Rio Paraná/del Rio Uruguay: Año de 1737," CA.

88 Robert H. Jackson, Frontiers of Evangelization: Indians in the Sierra Gorda and Chiquitos Missions (Norman, OK: University of Oklahoma Press, 2017).

89 Henry F. Dobyns, "An Appraisal of Techniques with a New Hemispheric Estimate," Current Anthropology 7, no. 4 (1966): 395-416; Henry F. Dobyns, Their Number Become Thinned: Native American Population Dynamics in Eastern North America (Knoxville: University of Tennessee Press, 1983). 
TABLE 8 Catastrophic mortality in $1737-40$

1737

\begin{tabular}{llrrrr} 
Mission & Population 1736 & Baptisms & Burials & $\begin{array}{l}\text { Crude birth } \\
\text { rate (CBR) }\end{array}$ & $\begin{array}{l}\text { Crude death } \\
\text { rate (CDR) }\end{array}$ \\
\hline Ytapúa & 4,650 & 212 & 484 & 45.6 & 104.1 \\
Trinidad & 1,733 & 70 & 267 & 40.4 & 154.1 \\
Jesús & 2,204 & 114 & 406 & 51.7 & 184.2 \\
\hline
\end{tabular}

$173^{8}$

\begin{tabular}{lrrrrr} 
Mission & Population $\mathbf{1 7 3 7}$ & Baptisms & Burials & CBR & CDR \\
\hline Ytapúa & 4,430 & 228 & 1,719 & 51.5 & 388.0 \\
Candelaria & 3,039 & 103 & 1,532 & 33.2 & 494.4 \\
Santos Cosme & 1,351 & 98 & 319 & 72.5 & 236.1 \\
Loreto & 2,099 & 131 & 917 & 62.4 & 436.9 \\
San Ignacio & 1,927 & 124 & 172 & 64.4 & 73.8 \\
San José & 3,302 & 156 & 1,874 & 47.2 & 567.5 \\
San Carlos & 3,202 & 104 & 820 & 32.5 & 256.1 \\
Apóstoles & 3,859 & 99 & 2,262 & $25 \cdot 7$ & 586.2 \\
Concepción & 6,402 & 186 & 2,168 & 29.1 & 338.6 \\
Mártires & 3,415 & 183 & 325 & 53.6 & 95.2 \\
La Mayor & 2,291 & 110 & 163 & 48.0 & 71.1 \\
San Xavier & 3,000 & 203 & 1,418 & 67.7 & 472.7 \\
San Nicolás & 6,324 & 263 & 1,116 & 41.6 & 176.5 \\
La Cruz & 4,444 & 205 & 629 & 46.1 & 141.5 \\
La Mayor & 3,905 & 110 & 163 & 48.0 & 71.1 \\
Santo Tomé & 3,593 & 91 & 505 & 33.5 & 186.1 \\
\hline
\end{tabular}

1739

\begin{tabular}{llrrrr} 
Mission & Population 1738 & Baptisms & Burials & CBR & CDR \\
\hline Ytapúa & 2,690 & 140 & 262 & 52.0 & 97.4 \\
San Ignacio & 1,934 & 113 & 228 & 58.4 & 117.9 \\
La Mayor & 2,262 & 22 & 1,279 & $9 \cdot 7$ & 565.4 \\
Mártires & 3,230 & 132 & 545 & 40.9 & 184.2 \\
La Cruz & 3,853 & 65 & 1,605 & 16.9 & 416.6
\end{tabular}


1739

\begin{tabular}{llrrrr} 
Mission & Population 1738 & Baptisms & Burials & CBR & CDR \\
\hline Sto Tomé & 2,041 & 62 & 471 & 30.4 & 230.8 \\
San Nicolás & 5,071 & 92 & 1,675 & 10.7 & 336.8 \\
San Luis & 4,327 & 82 & 2,396 & 20.3 & 565.1 \\
San Lorenzo & 4,814 & 160 & 2,681 & 33.2 & 557.0 \\
San Juan & 5,012 & 70 & 376 & 14.0 & 75.0 \\
\hline
\end{tabular}

1740

\begin{tabular}{llllll} 
Mission & Population 1739 & Baptisms & Burials & CBR & CDR \\
\hline San Juan & 5,151 & 71 & 2,400 & 14.1 & 485.0 \\
\hline
\end{tabular}

Two-year death rates at selected missions

Burials Population

\begin{tabular}{lrrrr} 
Mission & Two years of mortality & Two years & CDR & $\mathbf{1 7 3 9 / 4 0}$ \\
\hline Ytapúa & $1738-39$ & 1,981 & 447.2 & 2,591 \\
San Ignacio & $173^{8}-39$ & 400 & 207.6 & 1,849 \\
La Mayor & $1738-39$ & 1,442 & 629.4 & 711 \\
Mártires & $1738-39$ & 870 & 254.8 & 2,777 \\
Santo Tomé & $1738-39$ & 976 & 359.6 & 1,699 \\
La Cruz & $1738-39$ & 2,234 & 502.7 & 2,167 \\
San Nicolás & $1738-39$ & 2,791 & $817 \cdot 3$ & 1,978 \\
San Juan & $1739-40$ & 2,776 & 553.9 & 2,171 \\
\hline
\end{tabular}

SOURCE: "CATAlogo de LA NUMERACión ANNUAL DE LAS Doctrinas DEL Río PARANÁ/ DEL Río URUGUAY: AÑO DE 1738," CA; ROBERT H. JACKSON, DEMOGRAPHIC CHANGE AND ETHNIC SURVIVAL AMONG THE SEDENTARY POPULATIONS ON THE JESUIT MISSION FRONTIERS OF SPANISH SOUTH AMERICA, 1609-1803: THE FORMATION AND PERSISTENCE OF MISSION COMMUNITIES IN A COMPARATIVE CONTEXT (LEIDEN: BRILL, 2015), 213-15, 217-20; JACKSON, "LA POBLACIÓN Y TASAS VITALES DE LAS MISIONES JESUÍTICAS DE LOS GUARANí (ARgENTINA, BRASIL, PARAgUAY)," hIS: ANTIGUOS JESUITAS EN IBEROAMÉRICA 5, NO. 2 (JULY-DECEMBER 2017): 100-65. 
potential pool of brides was greatly reduced. The data from Ytapúa is clearer: marriages there totaled thirty-two in 1724 and sixty-five in 1728 , but they then jumped to 138 in the aftermath of the 1733 epidemic. The same occurred during and following the 1738-40 smallpox epidemic, as seen in increased numbers of marriages at some missions.

Not all of the missions experienced catastrophic mortality or population losses during the 173os, and particularly during the smallpox outbreak. The evidence demonstrates that the contagion did not spread to several missions, including San Miguel, Santo Ángel Custodio, and particularly Yapeyú. All three were relatively geographically isolated when compared with the other missions, which enabled the Jesuits stationed there to implement more effective quarantine measures. The same occurred during the next smallpox outbreak in 1763-65. The numbers speak for themselves: baptisms in 1738 and 1739 at San Miguel and Santo Ángel Custodio, respectively, totaled 522 and 459 as against 266 and 409 burials. While the populations of neighboring missions declined, those of San Miguel and Santo Ángel Custodio grew. Yapeyú is a particularly interesting case. It was located on the west bank of the Uruguay River at some distance from neighboring missions. Smallpox killed hundreds there during the 1718-19 epidemic, but the mission experienced robust population growth during the 1720 s and 1730 s, which was only slowed during the $173^{2-} 33$ epidemic that killed 1,209 (a crude death rate of 181.6 over two years). In the years 1723-40, the Jesuits baptized 7,145 and recorded 4,522 burials, or an excess of 2,623 baptisms over burials. The population grew from 4,352 in 1723 to 5,687 in $1740 .{ }^{90}$ However, this also meant that the population of the mission became increasingly vulnerable to contagion since a large percentage of the people had not been exposed to smallpox.

\subsection{The Treaty of Madrid and the Guarani Diaspora}

In 1750, Spain and Portugal ratified the Treaty of Madrid, which attempted to define the boundaries of Brazil and Spanish territory in the Río de la Plata region. The reigning Spanish monarch Fernando vi (1713-59, r.1746-59) was married to the Portuguese princess Infanta Bárbara $(1711-58)$ and implemented foreign policy initiatives more favorable to Portugal. The treaty contained provisions to adjust boundaries and recognize the Portuguese occupation of Rio Grande do Sul. The Portuguese surrendered Colonia do Sacramento in exchange for setting the boundary on the Uruguay River and the transfer to

$90 \quad$ Robert H. Jackson, "La población y tasas vitales de las misiones jesuíticas de los Guaraní (Argentina, Brasil, Paraguay)," IHS: Antiguos jesuitas en Iberoamérica 5, no. 2 (JulyDecember 2017): 100-165. 
Portugal of the territory occupied by the seven eastern Guaraní missions and many of the mission estancias. A secret provision of the treaty stipulated joint Spanish-Portuguese military action if the Guaraní resisted the transfer of jurisdiction, which they did. The treaty also contained provisions for other territorial changes. Spain transferred the Moxos mission Santa Rosa to Portugal, and in turn Portugal transferred San Cristóbal in Marañon to Spain. ${ }^{91}$

The effort to implement the treaty resulted in the rupture of the GuaraníJesuit-Spanish alliance, and in particular demonstrates what the Guaraní were willing to endure. ${ }^{92} \mathrm{~A}$ few years earlier, during the $1730 \mathrm{os}$, the alliance survived the series of severe mortality crises. The Treaty of Madrid, on the other hand, envisioned changes that the Guaraní were unwilling to accept, even when invoked in the name of the king.

The first confrontation occurred in February 1753 when a group of armed Guaraní led by Sepé Tiarayú $(1723-56)$ refused to grant the Spanish-Portuguese boundary commission passage to the territory of the missions beyond Santa Tecla. In April 1754, a force of four hundred Guaraní from San Luis, San Miguel, and San Lorenzo assembled on the Guacacay River to attack the Portuguese. At about the same time, armed Guaraní left several of the missions west of the Uruguay River to participate in the resistance: one hundred from Los Santos Mártires, two hundred from Concepción, 126 from Santo Tomé, one hundred from La Cruz, and five hundred from Yapeyú. ${ }^{93}$ When a force of Guaraní from Yapeyú and Santo Tomé confronted the Spanish army, 120 Guaraní died and forty-eight were taken prisoner, including their cacique (native chief) Paracatu (dates unknown). ${ }^{94}$ In October of the same year, a force of two thousand Guaraní and two hundred non-Christian allies confronted the advancing Portuguese force. ${ }^{95}$ The Luso-Spanish force and the boundary commission ultimately withdrew. As the Portuguese force reportedly numbered 1,150, ${ }^{96}$ the decision to withdraw may have been related to a problem of desertion from

91 Felipe de Hacedo, Buenos Aires, January 18, 1778, "Ynforme de la descripcion de la colônia del Sacramento y Puertos del Río de la Plata, situados al norte y sur de Buenos Ayres p[o]r D. Felipe de Haedo," in Jaime Cortesão, Tratado do Madrid: Antecedentes-colonia do Sacramento (1669-1749) (Rio de Janeiro: Biblioteca Nacional, 1954), 73.

92 See Lia Quarleri, Rebelión y guerra en las fronteras del Plata: Guaraníes, jesuitas e imperios coloniales (Buenos Aires: Fondo de Cultura Económica, 2009).

93 Quarleri, Rebelión y guerra en las fronteras del Plata, 243.

94 Quarleri, Rebelión y guerra en las fronteras del Plata, 273-74.

95 Felix Bécker, "La guerra guaranítica desde una nueva perspectiva: Historia, ficción e historiografía," Boletín americanista 32 (1982): 7-37; Lia Quarleri, "Gobierno y liderazgo jesuítico—guaraní en tiempos de guerra (1752-1756)," Revista de Indias 68, no. 243 (2008): 89-114.

96 In Cortesão, Tratado do Madrid, 277. 
the Spanish army. For example, a quarter of the force of two hundred from Corrientes deserted. ${ }^{97}$ The Spanish and Portuguese reorganized and invaded the mission territory again in 1755 . On February 10, 1756, a combined force of three thousand Spanish and Portuguese soldiers fought the Guaraní at the Battle of Caibaté, which resulted in the death of 1,511 Guaraní, with the Europeans suffering only four deaths. In the aftermath of the defeat of the Guaraní militia, the Luso-Spanish force occupied the seven missions, and the Guaraní were forced to relocate to the missions west of the Uruguay River. ${ }^{98}$

The general censuses documented the relocation of people from the eastern missions to the establishments located west of the Uruguay River. In some instances, the Jesuits relocated Guaraní to missions with which they had historical links. Examples include the relocation of the bulk of the population of San Francisco de Borja to Santo Tomé, from San Nicolás to Apóstoles, and from San Lorenzo to Santa María la Mayor. A second criterion was to relocate people to missions that had suffered catastrophic mortality during the 173 os and had not fully recovered. Ytapúa, San Francisco Xavier, and Concepción had suffered heavy mortality and hosted hundreds of refugees. In 1759, Ytapúa hosted 1,154, San Francisco Xavier 1,914 in the same year, and Concepción 1,360. At the time, it was believed that the transfers would be permanent, and the Jesuits sought to place the refugees where there was space or where there were historic or familial ties (see table 9).

Not all residents of the eastern missions voluntarily relocated west of the Uruguay River, as some instead sought refuge on the mission estancias east of the river and closer to their home communities. The 1759 census notes, for example, that 2,288 Guaraní from San Miguel and 1,548 from San Nicolás were on estancias. Two other documents provide additional details. A 1759 census enumerates the number of people from San Nicolás who had settled on the estancia of Ybicuy and had reportedly been there since June $1757 \cdot{ }^{99}$ The second document from 1758 reports a number of Guaraní who had sought refuge on the estancia of Santo Tomé and who were apprehended by Spanish forces in February and March. ${ }^{100}$ The number totaled 190 people, and the largest group

\footnotetext{
97 Cortesão, Tratado do Madrid, 243.

98 On the details of the relocation of the Guaraní from the seven eastern missions, see Jackson, Demographic Change and Ethnic Survival, $72-78$.

99 "Catalogo de la numeración anual de los Yndios Nicolaistas del año de 1759 que se juntaron en su estancia deste Ybicuy por junio de 1757," CA.

100 Joseph de Molina, Campo de San Ángel, March 2, 1758, "Relación de las personas que se han recogido de las familias de Yndios dispersos en la estancia de S[ant]o Thome y otros parajes por el Departamento del Puerto de San Ángel," AGN, Sala 9-6-10-3.
} 
TABLE 9 Distribution of the population of the seven eastern missions by mission

\begin{tabular}{|c|c|c|c|c|c|c|c|c|}
\hline Mission & $175^{6}$ & 1759 & 1762 & 1763 & 1764 & 1765 & 1766 & 1767 \\
\hline Candelaria & 749 & 805 & $55^{1}$ & 510 & & & & \\
\hline Corpus & & 494 & 442 & 424 & 317 & 361 & & $35^{6}$ \\
\hline Loreto & 605 & 1,015 & 651 & 614 & 443 & 321 & 136 & 403 \\
\hline San Ignacio & 747 & 959 & 866 & 875 & 819 & 847 & 187 & 805 \\
\hline \multicolumn{9}{|l|}{ Miní } \\
\hline Trinidad & 424 & 977 & 846 & 735 & 670 & 646 & 598 & 605 \\
\hline Santos & & 624 & 668 & 388 & & & & \\
\hline \multicolumn{9}{|l|}{ Cosme } \\
\hline Jesús & 419 & 882 & 708 & 666 & 627 & 646 & 354 & 672 \\
\hline Ytapúa & 790 & 1,154 & 1,057 & 1,044 & 886 & 915 & 940 & 926 \\
\hline Santa Rosa & 127 & 1,273 & 122 & 84 & & 22 & & \\
\hline Santiago & & 154 & & 17 & & & & \\
\hline $\mathrm{La} \mathrm{Fe}$ & & 69 & 83 & 100 & 47 & 47 & & 29 \\
\hline San Francisco & 1,401 & 1,914 & 1,228 & 1,187 & 911 & 386 & 131 & 349 \\
\hline \multicolumn{9}{|l|}{ Xavier } \\
\hline San Carlos & 1,518 & 1,462 & 1,170 & 694 & 32 & 36 & 13 & 35 \\
\hline San Jose & 1,425 & 1,395 & 1,042 & & & & & \\
\hline Apóstoles & $5^{12}$ & 1,466 & 109 & & & & & \\
\hline Concepción & 1,346 & 1,360 & $55^{2}$ & 538 & 354 & 418 & 342 & 401 \\
\hline Martires & & & 926 & 782 & 369 & 330 & 306 & 326 \\
\hline La Mayor & 1,233 & 1,536 & 33 & & & & & \\
\hline Santo Tomé & 1,785 & 3,721 & & & & & & \\
\hline La Cruz & & 61 & & & & & & \\
\hline Estancias & & 3,836 & & & & & & \\
\hline
\end{tabular}

SOURCE: JACKSON, DEMOGRAPHIC CHANGE AND ETHNIC SURVIVAL, 75-76; "FAMILIAS Y ALMAS DE LOS PUEBLOS DE LA OTRAVANDA DEL URUGUAY, Y EN QUE PUEBLOS ESTAN REPARTIDAS: 1 DE ENERO DE 1767," CA.

was forty-one captured on February 6, 1758. The report notes that the Guaraní came from different missions but does not enumerate which ones.

Guaraní residents of the missions also migrated to the disputed borderlands of the Banda Oriental and established new communities that were independent of the Jesuits. One such community was called Las Víboras, which was first settled in $175^{8}$ following the suppression of the Guaraní uprising. Some 1,500 people lived there in 1800 . An analysis of 1,045 entries in the 
baptismal registers from Las Víboras for the years 1770-1811 provides evidence of the diverse origins of the Guaraní residents of the community. The majority, 784 , or seventy-five percent of the total, were children of Guaraní who had once resided in the Jesuit missions. Others were from the Franciscan missions in southern Paraguay and from other areas in the larger Río de la Plata region. The residents of Las Víboras abandoned the community in 1846 as a result of an attack during a civil war in Uruguay. ${ }^{101}$

In 1761, after Carlos III (1716-88, r.1759-88) had assumed the throne following his brother's death, Spain and Portugal agreed to annul the Treaty of Madrid. Spain recovered the seven eastern missions and returned Colonia do Sacramento. In the same year, Spain entered the conflict known as the Seven Years' War (1755-63) as an ally of France and resumed the conflict with Portugal. A Spanish force that included mission militia took Colonia do Sacramento in 1763 . In the same year, Buenos Aires governor Pedro de Cevallos (1715-78, in office 1757-66) invaded Rio Grande do Sul. The Spanish first occupied the Portuguese forts of Santa Teresa and São Miguel and on April 24, 1763 occupied Rio Grande do São Pedro. Spain returned Colonia do Sacramento at the end of the conflict under the terms of the Treaty of Paris (1763) but refused to return Rio Grande do Sul based on its claims from the Treaty of Tordesillas (1494). An undeclared war continued in Rio Grande do Sul off and on for another fourteen years until the signing of the First Treaty of San Ildefonso in 1777.

In the aftermath of the abrogation of the Treaty of Madrid, the Guaraní started to return to their homes. By the time of the Jesuit expulsion in 1767 , the bulk of the Guaraní had returned to the sites of the seven eastern missions, but hundreds had not and apparently settled permanently on the host missions. Altogether, 4,907 from the eastern missions still resided in other communities, and 13,949 had returned to the seven eastern missions.

\subsection{Conclusions}

Popular myths emerged about the missions beginning with the writing of Candide. The Guaraní missions did not exist as a Jesuit-run state within a state and did not function as a "utopian socialist republic." The historical reality was quite different. The Jesuits administered missions among the Guaraní for some 150 years, and this group of missions came the closest to creating autonomous indigenous communities on the model of the pueblos de indios in the areas of advanced sedentary polities such as central Mexico and the Andean region. The Jesuits directed the creation of new communities from whole cloth and

101 Luis Rodolfo González Rissotto, "La importancia de las misiones jesuíticas en la formación de la sociedad Uruguaya," Estudios ibero-americanos 15, no. 1 (1989): 191-214. 
congregated thousands of people on the new communities built on the grid plan. The missions, which were the most populous communities in the larger Río de la Plata region, played a very important economic and political role in what was a marginal Spanish frontier region.

The Río de la Plata was a frontier contested between Spain and Portugal and the sedentary and non-sedentary indigenous populations that inhabited the region. Moreover, until the Bourbon reforms of the 1760 os, Spain dedicated relatively few resources and particularly military resources to the region, leading royal officials to rely heavily on the mission militia organized in the late 1630 in the face of raids by Portuguese colonists from Sao Paulo known as bandeirantes. The Jesuits expanded missions to areas close to Portuguese settlements, and in the 1620 and 1630 bandeirantes raided the missions and enslaved thousands of Guaraní. Ironically, Portugal was still ruled by the Spanish Habsburgs when the bandeirantes destroyed scores of missions. In 1641, the Guaraní mission militia, which was the only organized indigenous military forces authorized to carry firearms by the Spanish crown, routed a bandeirante force. The military organization on the missions constituted an important part of political organization and community identity. For the next century, royal officials mobilized the mission militia for service against the Portuguese and particularly in campaigns against Colonia do Sacramento, rebellious Paraguayan colonists in the 1720 s and 1730 , and hostile and mostly non-sedentary indigenous groups.

In response to the Portuguese threat, the Guaraní, in effect, formed an alliance with the Jesuits as representatives of the crown, and this alliance withstood crises such as plague and famine. However, the alliance ruptured with the negotiation of the 1750 Treaty of Madrid between Spain and Portugal that attempted to delineate the boundary of the spheres of influence of the two countries in South America. For a century, the Guaraní provided loyal service to the crown. However, the alliance ruptured due to the treaty providing for the transfer of the seven missions located east of the Uruguay River to Portugal, which resulted in an uprising as the residents of the seven missions attempted to defend their communities. A joint Spanish-Portuguese military expedition suppressed the uprising, and thousands of Guaraní temporarily relocated to missions located west of the river.

The Guaraní missions had large populations, with thousands of people living in the mission communities in a spatially compact urban plan. The missions communicated with neighboring Spanish settlements via two river highways that facilitated regional trade but also the spread of contagion. Epidemics spread to the mission populations about once a generation and in some instances caused catastrophic levels of mortality. Mobilizations of the mission militia exacerbated the effects of contagion, as was the case during a 
series of mortality crises between 1733 and 1740 that killed some ninety thousand Guaraní as a result of large-scale military mobilizations, famine, and the spread of epidemics. However, unlike other indigenous populations, the Guaraní mission populations rebounded or recovered following epidemics. The mission populations did not have gender imbalances, and there was an increase in the formation of new families and in birth rates following epidemics. The demographic patterns of the mission populations more closely paralleled contemporary European populations.

The missions among the Guaraní were unique in the sense of the dominant political, economic, and demographic role they played in the disputed Río de la Plata borderlands, a role that was greater than other frontiers where Jesuits administered missions. The missions among the Guaraní survived the Jesuits' expulsion in 1767 and continued to exist as viable communities under a system of civil administration until the early nineteenth century. However, the larger Río de la Plata region continued to be a zone of conflict, and war after 1810 resulted in the destruction of most of the former mission complexes as marauding armies crossed the region in an effort to assert sovereignty over the disputed lands. The contending armies left the former mission complexes in ruins and dispersed the Guaraní populations.

\section{$5 \quad$ The Jesuit Missions of Sinaloa and Sonora}

At the end of the sixteenth century and the start of the seventeenth, the Jesuits established missions on the northern frontier of colonial Mexico in regions that included the modern states of Durango, Chihuahua, Sinaloa, Sonora, and the two states of Baja California. This section discusses the Jesuit missions of Sinaloa and Sonora. The story of the Jesuit evangelization of the region began decades earlier in the immediate aftermath of the Spanish conquest of the Culhua-Mexica tribute state. In the 1520s, the Spanish in Mexico broke down into factions that competed for power and access to native labor and tribute. The faction opposed to Hernán Cortés $\left(1485^{-1547)}\right.$ governed Mexico between 1525 and 1529 through an audiencia (a type of court) headed by Nuño Beltrán de Guzmán (1490-1558), who was the president, and four oidores (judges). Cortés returned to Spain to appeal to the crown and returned to Mexico in 1529 with the title of Capitán General de la Nueva España (Captain general of New Spain). This marked a political defeat for Beltrán de Guzmán, who left Mexico City to organize the conquest of western and northwestern Mexico. At that time, Spanish control in western Mexico extended to what today is Michoacán. 
Beltrán de Guzmán organized an army of five hundred Spaniards, ten thousand natives from the Valley of Mexico, and another ten thousand from Michoacán. Beltrán de Guzmán used the army to conquer new territory, creating a jurisdiction that he called Nueva Galicia, which incorporated the modern states of Jalisco, Colima, Aguascalientes, Nayarit, Sinaloa, and parts of Zacatecas and San Luis Potosí. He subjugated the native populations of this region in brutal military campaigns starting in 1530 and in the process enslaved thousands, provoking a major native uprising known as the Mixtón War in the early 1540 os $^{102}$ In the wake of his expedition, Spaniards began establishing settlements with municipal governments in the newly conquered territory. They included Compostela, Guadalajara, Purificación, and San Miguel Culiacán in what today is Sinaloa. ${ }^{103}$ During the sixteenth century, the number of Spaniards in what today is Sinaloa and Sonora was very small, and in 1600 there were no more than five hundred or six hundred Spaniards in the region. ${ }^{104}$ Although the Spanish had established encomienda grants with rights to tribute and labor in the region, which also brought with it a theoretical obligation to evangelize the natives, there was little systematic missionary activity until the Jesuits arrived in the Villa de San Felipe y Santiago Sinaloa in 1591 and founded a colegio there. From their arrival until their expulsion, the Black Robes had a virtual monopoly on the evangelization of the native populations of Sinaloa and Sonora. ${ }^{105}$

While Beltrán de Guzmán was busy subjugating and enslaving natives in northwestern Mexico, another Spaniard named Álvar Núñez Cabeza de Vaca (1490-1559) participated in an odyssey that brought him to the Spanish frontier in Sinaloa and inspired an expedition to New Mexico in 1540 that passed through Sonora. Cabeza de Vaca's adventure began with his participation in an expedition organized in 1527 by Pánfilo de Narváez (1490-1528) to conquer Florida that ended in disaster. The expedition encountered considerable native resistance and lost contact with its ships. The Spaniards built rafts to try to navigate to Pánuco, which was a Spanish settlement located in what today is northern Veracruz, but most of the expedition perished in storms at sea. The only survivors from the expedition were Cabeza de Vaca, Alonso del Castillo Maldonado (dates unknown), Andrés Dorantes de Carranza (c.1500-50), and a Berber slave know as Esteban or Estebanico (c.1503-39). The Spaniards

102 On the Spanish conquest of western Mexico, see Ida Altman, The War for Mexico's West: Indians and Spaniards in New Galicia, 1524-1550 (Albuquerque: University of New Mexico Press, 2010).

103 Altman, War for Mexico's West, 57 .

104 Peter Gerhard, La frontera norte de la Nueva España (Mexico, DF: UNAM, 1996), 310.

105 Gerhard, La frontera norte de la Nueva España, 308. 
were stranded on the Texas Gulf Coast among natives collectively known as Karankawas but eventually walked from Texas to northern Sinaloa where they encountered a group of Spaniards at Bamoa on the Sinaloa River in $1536{ }^{106}$

Cabeza de Vaca and his companions became celebrities in Mexico City, with the story of their trek from Texas to Sinaloa inspiring the 1540-42 expedition to New Mexico organized by Francisco Vázquez de Coronado (1510-54). The expedition left Compostela (modern Nayarit) and passed through Sonora on the way to New Mexico. Fray Marcos de Niza $\left(c .1495^{-1558)}\right.$ had earlier passed through Sonora on an expedition to visit the New Mexico pueblos. The accounts of Cabeza de Vaca and the Vázquez de Coronado expedition were the first descriptions of the tribal polities in central and northern Sonora. A 1533 expedition headed by Diego de Guzmán (dates unknown) had already visited the Yoémem (Yaqui) who lived in what today is southern Sonora. Their accounts, for example, described the Tehuima (Opata) settlement the Spaniards called pueblo de corazones because of the deer hearts being cooked. This was Ures, later the site of a Jesuit mission established in 1644.

The Jesuits initiated their evangelization campaign on the Sinaloa River in the mid-159os, some sixty years after the Spanish subjugation of the region. The Jesuits established several missions for the local indigenous population, but the remains of these missions exist at only two sites. The first was at El Nio Icesave, founded in 1595 south of the Villa de San Felipe y Santiago de Sinaloa and Bamoa. The Jesuits designated the mission Nuestra Señora de Guadalupe. ${ }^{107}$ The mission at El Nio occupied two sites, and there are ruins at both. The older ruins are located in the cemetery of Pueblo Viejo, which is about two kilometers south of the modern town of El Nio. The second site is in El Nio. There was another Jesuit mission at Tamazula, also on the Sinaloa River south of El Nio. The existing church dates to the period following the Jesuit expulsion in the late eighteenth century. There was also a mission at the site of modern Guasave, but nothing remains of this establishment (see Map 2).

The natives of northern Sinaloa did not universally support the Jesuit evangelization campaign, leading the Black Robes to adopt tactics designed to undermine the status of their principal rivals, the shaman or traditional religious leader. An epidemic that struck the native population of the Sinaloa River Valley had given the traditional religious leaders effective propaganda in the cultural war with the Jesuits. As occurred on numerous occasions on

106 Rolena Adorno and Patrick Pautz, trans., The Narrative of Cabeza de Vaca (Lincoln: University of Nebraska Press, 2003).

107 Peter Masten Dunne, S.J., Pioneer Black Robes on the West Coast (Berkeley: University of California Press, 1940). 


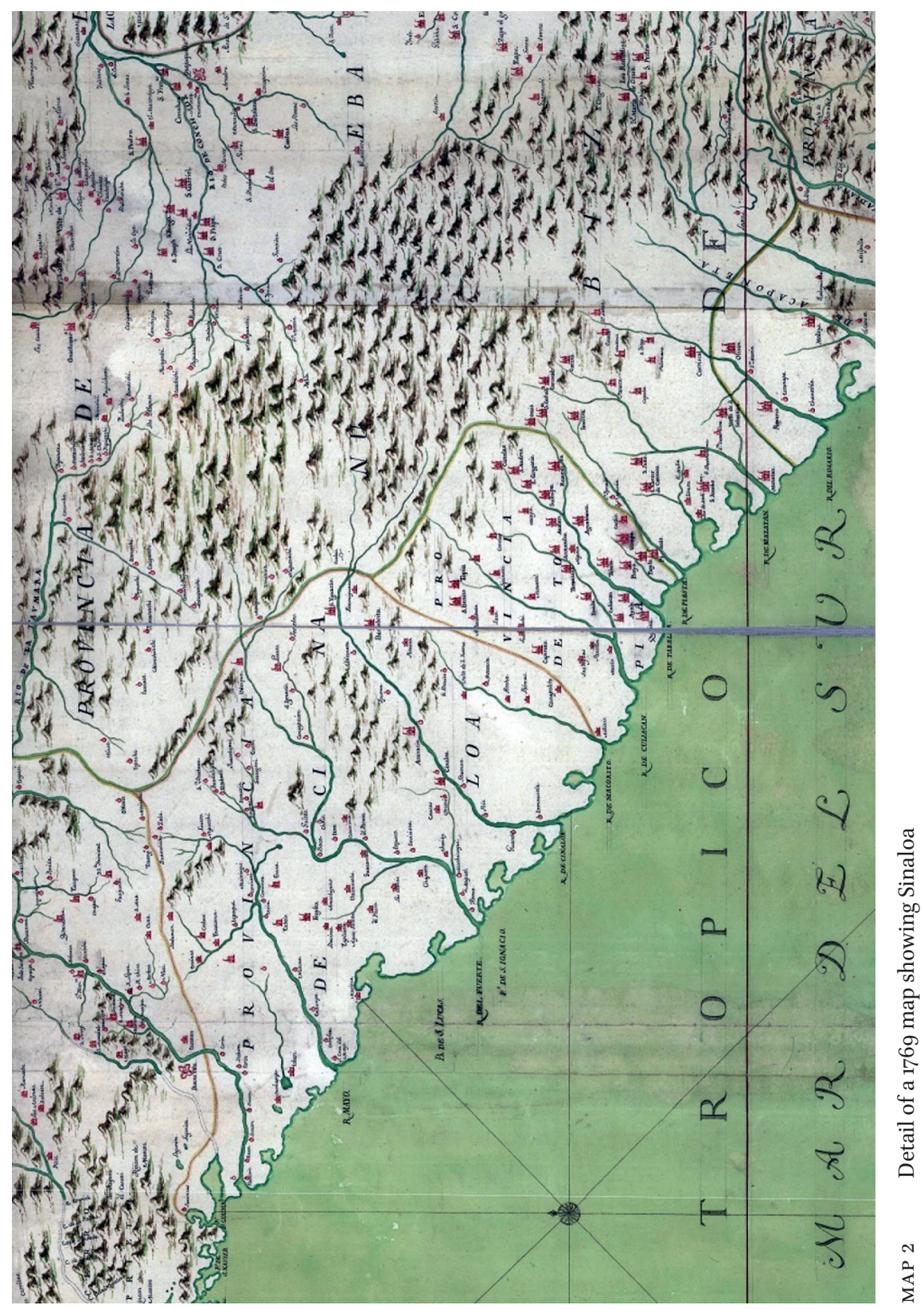


different mission frontiers, the traditional religious leaders blamed the missionaries for the epidemics. ${ }^{108}$ However, the Jesuits were able to use Spanish colonial authority and support from the military to overcome opposition to their mission program. There were other instances of resistance to the Jesuit mission program. The Upper Pimans (O'ohdam/Sobaipuri), for example, revolted twice against the Spanish and the Jesuit missions in 1695 and again in 1751, and in both instances the natives killed missionaries.

Over the next ninety years, the Jesuits moved northward along the coastal river valleys and into the mountains of the Sierra Madre Occidental, establishing missions among native communities of sedentary or semi-sedentary agriculturalists. In 1605, the Jesuits established missions among the Yoreme (Mayo) living along the Río Fuerte in northern Sinaloa and in 1614 in the Yoreme communities of the Mayo River Valley in southern Sonora. This was followed in 1617 by the first mission among the Yoémem (Yaqui), which was founded by Andrés Pérez de Rivas (1576-1655) and Tomás Basilio (1580-1654). Two years later, in 1619, Jesuits visited Sahuaripa, the residence of the sisibutari or paramount chief of the Tehuimas (Opata). The Black Robes established a mission in Sahuaripa in 1627. Over the next several decades, the Jesuits established new missions among the Tehuimas at sites such as Huepac and Arispe in the Sonora River Valley and Bacadéhuachi and Bavispe in the mountains of eastern Sonora. Beginning in 1620, the Jesuits established missions among the Névome (Pimas Bajos) and expanded the number of missions in later years to communities such as Yecora (1673) (see fig. 11). ${ }^{109}$ Around 1650, the Jesuits established a mission at the Tehuima community of Cucurpe, just south of the Upper Pima communities. Jesuits baptized some 16o Hymeris Pimas (modern Imuris), and the converts moved to a site closer to Cucurpe. ${ }^{110}$ This group of Hymeris was the first Upper Pimas (O'ohdam) the Jesuits baptized.

The establishment of missions in northern Sinaloa and southern Sonora also had demographic consequences for the native populations. Epidemics of highly contagious crowd diseases such as smallpox and measles decimated the populations, killing thousands. The Jesuits reported that by 1603 some four thousand natives had died on the Sinaloa River missions because of disease and warfare, and in 1617 the natives in the same area fled their communities following the outbreak of an epidemic. ${ }^{11}$

\footnotetext{
108 Dunne, Pioneer Black Robes, 31-36.

109 Dunne, Pioneer Black Robes, 80, 144. John Bannon, s.J., The Mission Frontier in Sonora, 1620-1687 (New York: Catholic Historical Society, 1955).

110 Bannon, Mission Frontier, 102.

111 Dunne, Pioneer Black Robes, 75.
} 


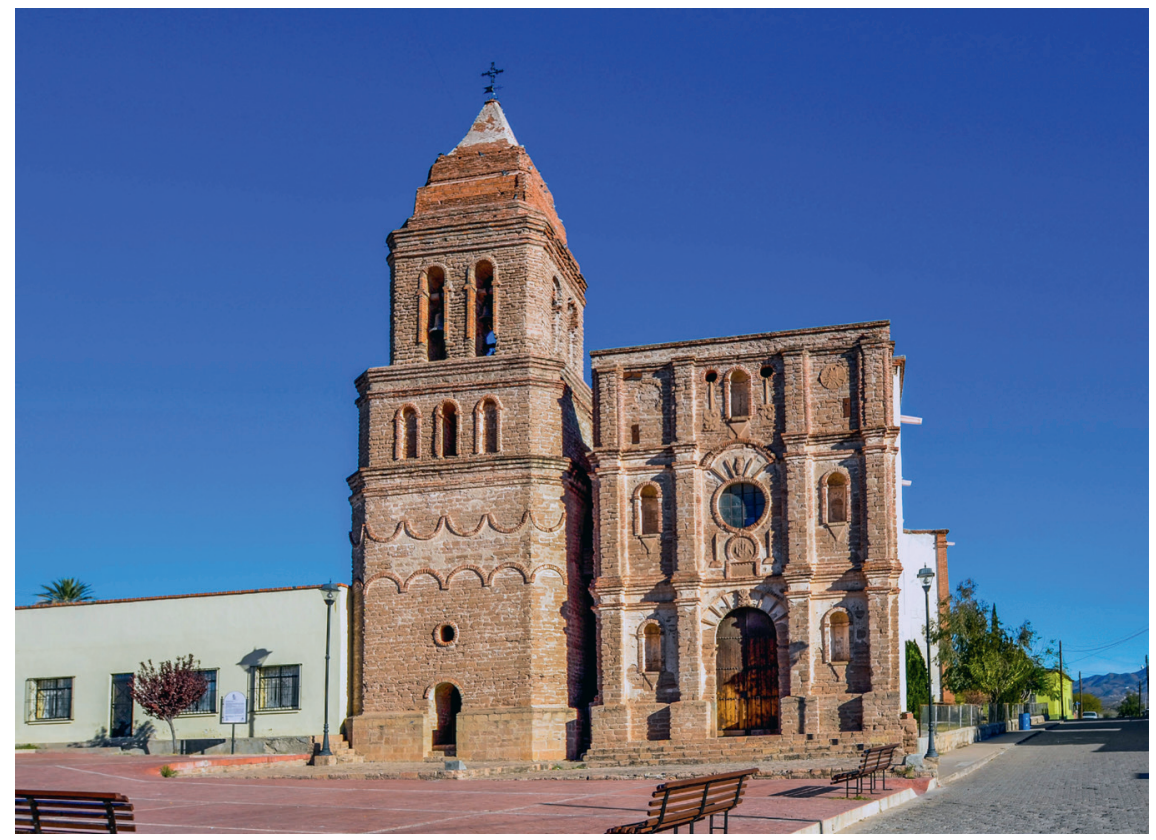

FIGURE 11 The Jesuit church at Arispe built in the 175 os

The Jesuits reported large numbers of baptisms in northern Sinaloa and southern Sonora. Between 1591 and 1631, the number of baptisms reached 151,240. However, disease and other factors reduced the size of the native populations. In the mid-162os, for example, twenty-seven Jesuits staffed missions with a reported population of $67,375{ }^{112}$ These figures suggest a rate of depopulation in excess of fifty percent over a period of some forty years (see tables 10 and 11).

The Jesuits had limited personnel and adopted the same organizational scheme used in the sixteenth-century central Mexican missions. They staffed the cabecera, or head town in a district, and then rode the circuit to visit communities without resident missionaries designated visitas. Although, at least on paper, the Jesuits administered communities with thousands of natives who had been baptized, the inhabitants of many communities only saw the missionaries periodically, and the level of conversion was shallow at best. This was particularly the case on the Pimería Alta frontier, where there was a chronic shortage of missionaries. In the early 175 os, for example, the Sobaipuri at Bac (W'ak) were not well instructed in Catholicism, and the Jesuits complained

112 Dunne, Pioneer Black Robes, 217, 220. 
TABLE 10 Jesuit missions in Sinaloa and Sonora in 1624

\begin{tabular}{llr}
\hline Missionary & Mission & Population \\
\hline Diego de Guzman & Mocorito & 900 \\
Alberto Clerici & Guasave & 3,000 \\
Blas de Paredes & Bamoa & 1,300 \\
Ignacio Zavala & Baboria & 1,050 \\
Leonardo Latini/Patino & Chicorato & 1,400 \\
Juan Calvo & Yecorato & 920 \\
Vicente Aguila & Ahome and Suaqui & 5,058 \\
Martin Azpilcueta & Tehueco & 2,567 \\
Juan Castini & Sinaloa & 6,570 \\
Juan Varela & Tecori & 10,400 \\
Diego de la Cruz & Nobor & 5,500 \\
Miguel Godínez & Tepahui & 5,400 \\
Pedro Méndez & Potam & 7,250 \\
Juan Ardenas & Vicam & 4,000 \\
Guillermo Otton & Torin & 3,800 \\
Francisco Olinano & Tesamo & 5,400 \\
& Tecoripa & 2,750 \\
\hline
\end{tabular}

SOURCE: PETER MASTEN DUNNE, S.J., PIONEER BLACK ROBES ON THE WEST COAST (BERKELEY: UNIVERSITY OF CALIFORNIA PRESS, 1940), 217.

TABLE 11 Baptisms in the Sinaloa-Sonora missions, 1591-1631

\begin{tabular}{lrrllrll}
\hline Year & Baptisms & Year & Baptisms & Year & Baptisms & Year & Baptisms \\
\hline $1591-1609$ & 25,897 & 1615 & 1,703 & 1621 & 11,340 & 1628 & 5,474 \\
1610 & 2,586 & 1616 & 4,155 & 1622 & 8,343 & 1629 & 4,762 \\
1611 & 1,745 & 1617 & 4,675 & 1623 & 11,221 & 1630 & 8,697 \\
1612 & 2,075 & 1618 & 4,479 & 1624 & 6,000 & 1631 & 8,808 \\
1613 & 1,613 & 1619 & 7,421 & $1625-26$ & 13,056 & & \\
1614 & 5,420 & 1620 & 7,600 & 1627 & 4,170 & & \\
\hline
\end{tabular}

SOURCE: DUNNE, PIONEER BLACK ROBES ON THE WEST COAST, 218. 
that there were no catechists to instruct them in Christian doctrine. ${ }^{113}$ The Jesuits had first visited Bac in the early 169os, some sixty years earlier, but visited the community only sporadically after that date.

The Magdalena parish archive in Magdalena de Kino, Sonora, preserves two baptismal registers that date to the 168 os, the oldest such record for the region, and show the complexity and fluidity of the evolving multi-ethnic frontier population. The larger baptismal register contains the baptisms of 448 natives, mostly Tehuima (Opata) and Pima, five settler children, twelve Seri or Tepoca from the fringes of Spanish Sonora on the coast of the Sea of Cortes (Gulf of California), two Yoémem (Yaqui) from southern Sonora, and two nonChristians, most likely Pima, whom the missionaries labeled as "gentiles." The second, smaller baptismal register is titled "Hiaquis (Yoémem) and Servants of the Settlers." The Yoémem came to the frontier to work for the settlers living in the region. This register records the baptisms of seventy-eight native children, five settler children, four Tehuima, one Névome, five Seri, one Pima, and fourteen Yoémem. The missionaries had to coexist with a growing settler population, and at times there were conflicts between the missionaries and the settlers. Some natives elected to leave the missions and work for the settlers. The Sonora frontier was fluid, and there were movements of people. ${ }^{114}$

The Jesuits modified the economy of the native populations, with a dual economy existing on the missions. The natives continued to practice subsistence agriculture, but they also provided labor for agricultural production and livestock ranching for the missionaries, who controlled the distribution and sale of crops and animals. The natives practiced agriculture based on the cultivation of corn, beans ( frijol), and squash. The missionaries introduced new crops from Europe including wheat, chickpeas, and lentils. The missionaries also introduced Old World domesticated livestock, including cattle, sheep, goats, horses, donkeys, and mules. Inventories and reports recorded the numbers of livestock that belonged to the missions and were under the control of the missionaries. The missionaries had some livestock slaughtered to provide meat to the natives living on the missions but also sold animals in the emerging market economy. Individual native families may have owned livestock, but those animals would not have been included in the count of mission animals (see table 12).

\footnotetext{
113 Jackson, Indian Population Decline, 23.

114 Robert H. Jackson, "Demographic Change in Northwestern New Spain," Americas 41, no. 4 (April 1985): 462-79, here 464 .
} 
TABLE 12 Livestock at Movas mission, in selected years

\begin{tabular}{lrlrccc}
\hline Year & Cattle & Horses & Mules & Sheep and goats & Donkeys & Oxen \\
\hline 1737 & 190 & 408 & 6 & 6 & 430 & \\
1741 & 777 & 423 & 49 & 138 & & \\
1743 & 461 & 545 & 48 & 97 & 6 & 38 \\
1744 & 374 & 496 & 34 & 424 & 5 & 31 \\
1752 & 339 & 349 & 7 & 1,025 & 2 & 15 \\
1761 & 1 , Оo० & 710 & 110 & & 6 & \\
\hline
\end{tabular}

SOURCE: MARIA SOLEDAD ARBELAEZ, "THE SONORAN MISSIONS AND INDIAN RAIDS OF THE EIGHTEENTH CENTURY," JOURNAL OF THE SOUTHWEST 33, NO. 3 (AUTUMN 1991): 366-86, HERE $378-81$.

Eusebio Francisco Kino (1645-1711) organized the expansion of Jesuit missions into the region inhabited by the peoples the Spanish identified as Upper Pimas (Pimas Altos, O'odham/Sobaipuri), who were related linguistically to the Lower Pimas in central Sonora. Kino arrived in Mexico in 1681 and two years later was sent on an expedition to colonize Baja California headed by Isidro de Atondo y Antillón (c.1639-91). The Spanish settlement at San Bruno survived for two years, but then Atondo y Antillón ordered the settlement abandoned because the arid environment limited the potential for agriculture and also because of the hostility of the local native population. Kino was transferred to Sonora and used the northern mission at Cucurpe as a base from which to establish a new mission named Dolores in 1687. From Dolores, Kino visited the native communities in the region the Spanish named the Pimería Alta and organized a network of missions at existing Upper Pimas communities. Kino envisioned directing a chain of missions staffed by Jesuits, but the reality was that few missionaries were available for the north Sonora mission frontier (see table 13) (see Map 3).

Aspects of the Upper Piman lifestyle and socio-economic organization complicated the Jesuits' efforts to evangelize the natives and change their way of life. Upper Piman communities where the Jesuits established their missions were located in river floods in a dispersed pattern the Spanish described as rancherias. The Jesuit goal was to congregate the natives into more nucleated communities built around the church and mission complex. One hypothesis maintains that the Pimans adopted a more dispersed settlement pattern in the face of the spread of epidemics of lethal crowd diseases such as smallpox and 
TABle 13 The Kino missions in the Pimería Alta

\begin{tabular}{|c|c|c|c|c|c|}
\hline Mission & $\begin{array}{l}\text { Date organized } \\
\text { by Kino }\end{array}$ & Date staffed & Visita & $\begin{array}{l}\text { Date organized } \\
\text { by Kino }\end{array}$ & $\begin{array}{l}\text { Date } \\
\text { staffed }\end{array}$ \\
\hline \multirow[t]{2}{*}{$\begin{array}{l}\text { Dolores de } \\
\text { Cosari }\end{array}$} & 1687 & 1687 & Remedios & 1687 & \\
\hline & & & Cocóspera & 1687 & 1768 \\
\hline $\begin{array}{l}\text { San Ignacio } \\
\text { de Caborica }\end{array}$ & 1687 & 1693 & Magdalena & 1687 & \\
\hline \multirow[t]{2}{*}{$\begin{array}{l}\text { San Pedro y } \\
\text { San Pablo de } \\
\text { Tubutama }\end{array}$} & 1689 & 1694,1720 & $\begin{array}{l}\text { Ymuris } \\
\text { Santa Teresa }\end{array}$ & $\begin{array}{l}1687 \\
1689\end{array}$ & \\
\hline & & & $\begin{array}{l}\text { Oquitoa } \\
\text { Atil }\end{array}$ & $\begin{array}{l}1689 \\
175^{6}\end{array}$ & $1780 \mathrm{~s}$ \\
\hline $\begin{array}{l}\text { La Purísima } \\
\text { Caborca }\end{array}$ & 1689 & $1694,175 ?$ & Busanic & 1689 & \\
\hline Saric & 1689 & $175^{6}$ & $\begin{array}{l}\text { Pitiqui } \\
\text { Aquimuri } \\
\text { Busanic } \\
\text { Tucubavia }\end{array}$ & $\begin{array}{l}1689 \\
1689 \\
1689 \\
1689\end{array}$ & \\
\hline $\begin{array}{l}\text { Los Santos } \\
\text { Ángeles } \\
\text { Guevavi }\end{array}$ & 1691 & 1732 & Sonoita & 1691 & \\
\hline \multirow[t]{2}{*}{$\begin{array}{l}\text { San Xavier del } \\
\text { Bac }\end{array}$} & 1692 & $1731,175^{6}$ & $\begin{array}{l}\text { Tumacacori } \\
\text { Tucson }\end{array}$ & $\begin{array}{l}1691 \\
1692\end{array}$ & 1768 \\
\hline & & & Cuyoabagum & 1699 & \\
\hline $\begin{array}{l}\text { Santa María } \\
\text { Soamca }\end{array}$ & 1689 & 1732 & San Lazaro & 1689 & \\
\hline Sonoyta & 1697 & $175^{1}$ & Bacoancas & 1689 & \\
\hline
\end{tabular}

SOURCE: ROBERT H. JACKSON, INDIAN POPULATION DECLINE: THE MISSIONS OF NORTHWESTERN NEW SPAIN, 1687-1840 (ALBUQUERQUE: UNIVERSITY OF NEW MEXICO PRESS, 1994), 16-27. 


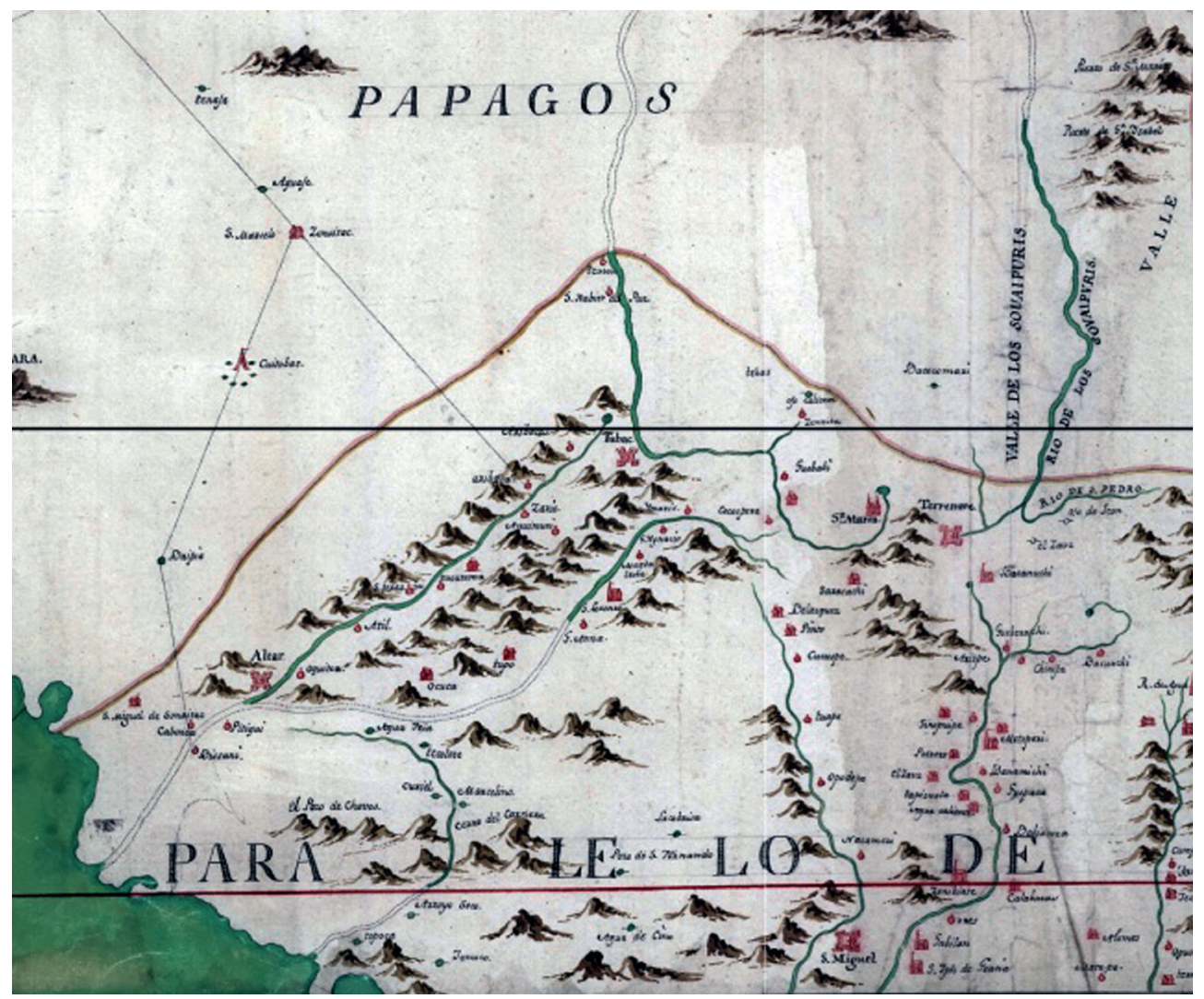

MAP 3 Central and northern Sonora from a 1769 map

measles. ${ }^{115}$ A second problem that persisted following the arrival of the missionaries and complicated their evangelization program was that the Upper Pimans occupied their communities in the river floodplains only on a seasonal basis and left to exploit other food resources such as fruit. At the same time, another pattern of seasonal transhumance facilitated the conversion process. The Upper Pimans that lived in the more arid sections of the region and beyond the river valleys where the Jesuits operated their missions, the peoples the Spanish called the Papagos, came to the river valleys on a seasonal basis to plant crops. The Jesuits took advantage of their presence to pressure them to remain in the missions. ${ }^{116}$ In the 1740 , the Jesuits closed the Dolores

115 Jackson, Indian Population Decline, 16.

116 Jackson, Indian Population Decline, 19. 
mission and relocated the surviving population to Cocóspera. ${ }^{117}$ The process of resettling the communities administered from Guevavi and later Tumacacori was typical. From the 173 os to the 176 os, the Jesuits resettled the populations of twelve communities onto four settlements: Guevavi, Tumacacori, Calabazas, and Sonita. Between 1741 and 1763 , the Jesuits stationed on Guevavi baptized 1,144 Pimans as well as thirty-eight non-Pimans. In 1754, 316 Pimans lived on Guevavi and three visitas, 507 in 1761 on the same number of settlements, 488 in 1766 , 310 in 1768 , and 236 in 1774 following the Jesuit expulsion living on two settlements. Within another decade, only one settlement remained, Tumacácori. ${ }^{118}$

Baptismal and burial registers exist for a number of the northern Sonora missions, although they are not complete (see table 14). However, the record does show the ethnic diversity of the frontier indigenous population and the colonial practice of slavery. As already discussed, Cucurpe was a community predominantly of Tehuimas (Opata) but administratively was included in the group of missions that Kino organized after 1687. A small number of Yoémem (Yaqui) and Névome came to work in the northern frontier region, and there were baptisms of Seri, Apache, and Quechan or Yuma from the Colorado River region. These were mostly war captives and children distributed as servants to settler families. In the sample of baptisms, there were, for example, baptisms of 163 Quechan or Yuma. The last category was that of nijora, which was a group of slaves held by frontier settler families, most of whom came from the Colorado River region as well. The majority were most likely Quechan or Yuma. There was an active slave trade in Nijoras cloaked in the legal fiction that they were war captives that had been taken in battles between different indigenous groups and had been "ransomed" by the settlers who thus saved their lives and put them to work. The sample of baptisms includes 286 Nijoras. The largest group was different Pima groups.

The Jesuits directed the construction of modest churches and cloisters built of adobe on the Pimería Alta missions. Kino directed the construction of small adobe chapels at a number of the villages he designated as mission cabeceras. A 2009 archaeological study examined what may have been the small chapel Kino had built in the Guevavi mission. ${ }^{119}$ When missionaries arrived to staff Guevavi, they directed the construction of a complex that was typical of the Jesuit missions in the Pimería Alta. The church was a small single-nave adobe

117 Jackson, Indian Population Decline, 26.

118 Jackson, Indian Population Decline, 23, 29, 62.

119 Deni Seymour, "Father Kino's 'Neat Little House and Church' at Guevavi," Journal of the Southwest 51, no. 2 (Summer 2009): 285-316. 
TABLE 14 Baptisms recorded on the northern Sonora missions

\begin{tabular}{|c|c|c|c|c|c|c|c|c|c|}
\hline Mission & Years & Pima & Yaqui & Nebome & Opata & Seri & Apache & Yuma & Nijora \\
\hline Cucurpe & $1681-1711$ & 4 & 2 & o & 444 & 12 & o & o & $\mathrm{o}$ \\
\hline Cucurpe & $1686-1703$ & 1 & 14 & 1 & 82 & 5 & o & o & $\mathrm{o}$ \\
\hline Magdalena & $1698-1718$ & $25^{8}$ & o & o & $\mathrm{O}$ & o & 6 & o & 1 \\
\hline Magdalena & $1744-76$ & 211 & 5 & $\mathrm{o}$ & 1 & o & 5 & o & 17 \\
\hline Magdalena & $1810-30$ & 24 & 91 & $\mathrm{o}$ & 1 & o & 3 & 11 & o \\
\hline San Ignacio & $1720-62$ & 2,625 & 37 & $\mathrm{O}$ & 4 & 10 & 10 & o & 70 \\
\hline Soamca & $173^{2-68}$ & 1,641 & 1 & o & o & o & 10 & $\mathrm{o}$ & 8 \\
\hline Soamca & $1743^{-53}$ & $3^{61}$ & o & o & o & o & 1 & $\mathrm{o}$ & $\mathrm{o}$ \\
\hline Guevavi & $1741-63$ & 1,144 & 4 & o & 2 & 1 & 10 & 1 & 20 \\
\hline Tumacacori & $1773^{-1825}$ & 290 & 9 & o & 1 & o & 18 & 19 & 5 \\
\hline Ati & $1757-1827$ & 347 & 3 & o & o & o & 1 & 2 & 13 \\
\hline Oquitoa & $1757-1841$ & 333 & 4 & o & 3 & o & 7 & 8 & 19 \\
\hline Oquitoa & $1778-1830$ & 3 & 43 & o & o & o & o & 3 & 7 \\
\hline Caborca & $1764-1838$ & 1,121 & 66 & o & 22 & 2 & 1 & 100 & 55 \\
\hline Pitiqui & $177^{2-1845}$ & 325 & 68 & 1 & 2 & 7 & o & 8 & 36 \\
\hline Bisanig & $1768-18 \circ 3$ & 296 & 1 & o & 1 & o & 1 & o & 23 \\
\hline Tubutama & $1768-1833$ & 241 & 13 & o & 3 & o & 2 & 9 & 12 \\
\hline Tubutama & 1804-37 & 24 & 20 & $\mathrm{o}$ & 6 & $\mathrm{O}$ & o & 1 & o \\
\hline Cocóspera & $1822-36$ & 64 & o & o & o & o & o & 1 & o \\
\hline Total & & 9,313 & 381 & 2 & 572 & 37 & 75 & 163 & 286 \\
\hline
\end{tabular}

SOURCE: JACKSON, INDIAN POPULATION DECLINE, 29.

structure and the cloister was similarly modest in size and was also built of adobe. ${ }^{120}$ The Piman residents of the missions lived in their traditional ovalshaped housing. The church of San Ignacio de Caborica is also likely to be a Jesuit construction. After the Jesuit expulsion in 1767, the Franciscans from the apostolic college of Santa Cruz in Querétaro who replaced the Jesuits on the central and northern Sonora missions directed the construction of more substantial churches at Caborca, Pitiqui, Bac (W'ak), and Tubutama, among other sites, and had the Jesuit church at Cocóspera rebuilt.

120 William Robinson and Mark Barnes, "Mission Guevavi: Excavations in the Convento," The Kiva 42, no. 2 (Winter 1976): 135-75. 


\subsection{Conclusions}

The Jesuits encountered mostly sedentary indigenous groups in Sinaloa and Sonora that practiced shifting agriculture, hunted, and collected wild plant foods such as cactus fruit. They lived in small communities in river floodplains, and the Jesuits grafted their mission structure onto the existing settlement pattern. The Sinaloa-Sonora frontier evolved as a fluid and multi-ethnic society, and the Jesuits shared the space and competed with the growing settler population attracted by the discovery of mines and lands for ranching and farming. The indigenous populations on the missions experienced demographic changes and particularly the effects of epidemics of smallpox and other maladies. There were also instances of armed resistance to the new colonial order. However, the indigenous populations persisted and persist to this day.

The Jesuits introduced a new set of religious beliefs that the indigenous peoples embraced to a certain extent. However, they also retained pre-Hispanic beliefs, as seen, for example, in the continued practice of the "Danza del venado" (Deer dance), which recreates the hunting of the deer (a deity), and uses a notched stick-like instrument known as ajirúkia that recreates the sound the deer makes and is used only for this sacred dance. There are generally three jirúkia used in the dance. It is still practiced by the Yoreme and Yoémem of northern Sinaloa and southern Sonora, particularly during semana santa (holy or Easter week) and in conjunction with the pascola, which is an adaptation of a practice introduced by the Jesuits. A ramada is built with four altars oriented toward the four cardinal directions, and the dances are performed before the altars in the ramada. ${ }^{21}$ The indigenous populations thus redefined the new faith on their own terms.

\section{Jesuit Missions among Non-sedentary Indigenous Populations}

The two previous case studies examined Jesuit missions among indigenous groups that practiced different forms of agriculture and lived a more or less sedentary way of life. The process of social engineering was relatively easy. However, the Jesuits also attempted to evangelize and transform the social structure and lifestyles of non-sedentary groups, and this proved to be more of a challenge. For one, the introduction of European modes of agricultural labor would have entailed a radical shift in gender roles for non-sedentary groups and in some cases the erasure of the ways in which men gained social status

121 Pablo Sánchez Pichardo, "Las danzas de pascola y venado: Su cultura material y comportamiento ritual," Anales de antropología 46 (2012): 135-53. 

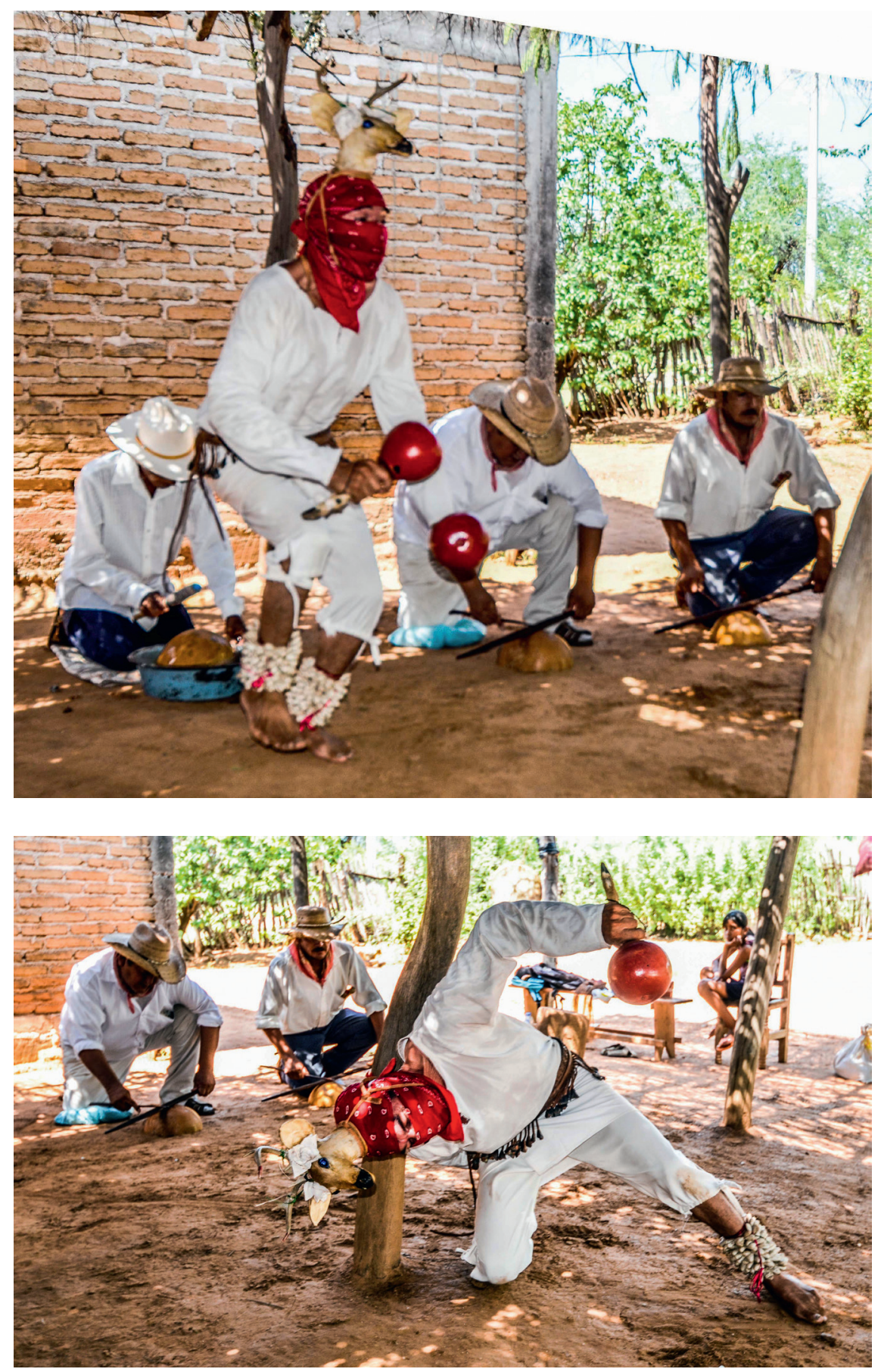

FIGURE 12 The Danza del venado in a Yoreme community in northern Sinaloa 
such as in hunting and waging war. In many non-sedentary groups, women collected wild plant foods and men generally did not, and as the nature of agricultural work was perceived as being similar to the collection of plant food, it posed a problem for male machismo. This section examines missions established among non-sedentary groups in the province of Paraquaria and on the northern frontier of colonial Mexico in Baja California, which was unique in that the Jesuits themselves funded the missions with no royal support.

\subsection{Non-sedentary Peoples in Paraquaria}

The Jesuit province of Paraquaria covered an extensive territory in what today are the countries of Argentina, Bolivia, Brazil, and Paraguay. The Guaraní and the groups that evolved into the Chiquitanos through a process of ethnogenesis were agriculturalists who practiced shifting swidden agriculture, and the Jesuit missions established among these groups were important in their evangelization program. However, there were also non-sedentary groups that the Jesuits attempted to evangelize. The Chaco region was one porous frontier between indigenous agriculturalists and non-sedentary groups, and the Jesuits established missions there in the seventeenth and eighteenth centuries in an attempt to evangelize the different groups who lived in the region. The Banda Oriental (modern Uruguay) and Rio Grande do Sul, which was a frontier zone contested by Spain and Portugal, was a second, and this frontier zone is the subject of the first case study of Jesuit efforts to evangelize non-sedentary groups.

The Spanish attempted to identify and label the different indigenous groups inhabiting the region and living in tolderías or mobile camps. The Spanish identified several groups, including Yaros, Charrúa, and Guenoa Minuanos. The tolderías interacted with the Jesuit missions established among the Guaraní as raiders but also engaged in trade. ${ }^{22}$ Charrúa tolderías interacted primarily with the Jesuit mission los Reyes Yapeyú, which was established on the west bank of the Uruguay River in 1627. Similarly, Guenoa Minuanos tolderías engaged in

122 Diego Bracco, "Charrúas, bohanes, pampas y guenoa minuanos en los pueblos de misiones," Folia histórica del Nordeste 27 (September-December 2016): 199-212; Norberto Levinton, "Guaraníes y charrúas: Una frontera exclusivista-inclusivista," Revista de história regional 14, no. 1 (Summer 2009), 49-75; Levinton, "Las estancias de Nuestra Señora de los Reyes de Yapeyú: Tenencia de la tierra por uso cotidiano, acuerdo interétnico y derecho natural (misiones jesuíticas del Paraguay)," Revista complutense de historia de América 31 (2005): 33-51. Bracco identifies the guenoa minuano as a single group, whereas Erbig, Where Caciques and Mapmakers Meet, identifies them as two distinct groups. Each toldería was independent, and the ethnic designations were a Spanish and Portuguese construct. In this discussion, I follow the convention of Bracco. 
commerce with the missions of La Cruz, Yapeyú, and Santo Tomé, as reported in the 167 os. $^{123}$ Some entered the missions.

In 1702, the Jesuits established a short-lived mission named San Andrés de Yaros following a 1701-2 military campaign against the non-sedentary indigenous groups living in the Banda Oriental who had allied with the Portuguese during the War of Spanish Succession (1701-13) and raided the Jesuit missions. ${ }^{124}$ However, it collapsed when the natives abandoned the mission. ${ }^{125}$ The Jesuits congregated small numbers of non-sedentary indigenous peoples on the missions among the Guaraní following the 1701-2 military campaign that ended in the Battle of Yi. ${ }^{126}$ For example, the Jesuits reported the resettlement of fortysix non-Christians on Corpus Christi mission. ${ }^{127}$ In the same year, the Jesuits settled forty Yaros on Candelaria mission. The Jesuits reported that they catechized the adults daily in the morning and afternoon. ${ }^{128}$

The conflict with the non-sedentary groups in the Banda Oriental continued for several more years. A 1705 report noted continued raids by Yaros and other groups on mission livestock. ${ }^{129}$ The conflict escalated in 1707 and 1708 as nonChristian Guenoa Minuanos, Yaros, and Bohanes allied with the Portuguese continued to raid missions and Spanish livestock, attacking mission residents and sheltering fugitives from the missions. In one incident, hostile natives attacked a raft from Santo Tomé mission. They also attacked mission estancias, including those of La Cruz and Yapeyú. In the last attack, the raiders killed thirteen and took another twenty-six women and children captive. In November of 1707, the Jesuits sent a force of 250 militia from La Cruz, Yapeyú, and San Francisco de Borja to pursue and punish the raiders and decisively defeated the hostile Guenoa Minuano bands. ${ }^{130}$

Periodic hostilities continued with the non-sedentary indigenous groups through the end of the eighteenth century. Military campaigns in 1749, 1750, and 1751 forced hundreds of Charrúa to settle on a Franciscan mission named

123 Diego Bracco, "Los guenoa minuanos misioneros," Memoria americana: Cuadernos de etnohistoria 24, no. 1 (2016): 33-54, here 34.

124 For a discussion of the Spanish-Jesuit conflict in the Río de la Plata region and the Jesuit mission expansion after 168o, see Jackson, Regional Conflict and Demographic Patterns, 40-41. The Portuguese hoped to distract the mission militia and prevent it from participating in a later siege of Colonia do Sacramento.

125 Levinton, "Las estancias de Nuestra Señora de los Reyes de Yapeyú," 36.

126 Erbig, Where Caciques and Mapmakers Meet, 17-18.

127 Jackson, "Demographic Patterns in the Jesuit Missions of the Río de la Plata Region."

128 "Annua de los dos pueblos de la Candelaria y de S. Cosme y S. Damian por 1702," CA.

129 "La carta annua [de las misiones del Uruguay] del año pasado de 1705," CA.

130 Francisco Medrano, San Francisco de Borja, February 14, 1708, "Estado y motivos de la guerra que se hace a los Indios Guenoas, Yaros y Mbohas," CA. 
Concepción de Cayastá, which was located at what had been the first site of Santa Fe on the eastern bank of the Paraná River. ${ }^{131}$ Guenoa Minuanos also sought refuge on the missions following the campaigns. Similarly, some 650 infieles (non-Christians/pagans) sought refuge on La Cruz, Yapeyú, and San Francisco de Borja in 1794, and this group included 130 Guenoa Minuanos. ${ }^{132}$

In 169o, the Jesuits established Jesús María mission close to San Francisco de Borja. The population of Jesús María was an open population, which means that the Jesuits congregated non-Christians on the missions. The Jesuits reported baptisms of twenty-one adults in 1690 when the mission was first established, ten in 1691 , fourteen in 1693 , thirty-one in 1695 , one in 1700 , twenty-three in 1705, and eleven in $1708 .{ }^{133}$ However, the population also fluctuated (see table 15), which suggests a pattern similar to missions established among other non-sedentary indigenous groups such as those in the Chaco region. Guenoa Minuanos settled on the mission but some later left. The pattern of fluctuations in the population suggests the Jesuits failed to persuade the natives to abandon their traditional way of life and the social norms that defined gender roles between men and women. ${ }^{134}$ The mission censuses recorded a population of 324 when the Jesuits established Jesús María in 169o. This reached a record high of 357 in 1714; it stood at 283 in 1717 and then dropped to 238 in 1719 following the smallpox epidemic of 1718-19. The 1720 mission census showed the mission merged with San Francisco de Borja, and the 1724 population count did not record the mission at all.

Following the closure of Jesús María, the Jesuits made several attempts to establish new missions for Guenoa Minuanos tolderías. In 1727, a Guenoa Minuano tolderías requested the establishment of a new mission in their own territory. Similarly, the Jesuits founded two missions, one in 1746 and a second in 1750 , in the Banda Oriental in what today is Uruguay. The second was located

131 Diego Bracco, "Charrúas y aculturación: La primera década en Concepción de Cayastá (1750-1760)," Revista Tefros 14, no. 1 (2016): 6-52.

132 Bracco, "Guenoa minuanos," 44.

133 "Annua de las doctrinas del Paraná y Uruguay [...] del año de 1693," CA; "Annua de las doctrinas del Paraná y Uruguay [...] del año de 1694," CA; "Estado de las reducciones del Paraná de este año de 1698," CA; "Annua doctrinas del Uruguay del año de 1698," CA; "Anuas de las misiones del Uruguay del año de 1700," CA; "Estado de las doctrinas del Uruguay al fin del año de 1705," CA; "Estado de las doctrinas del Uruguay al fin del año de 1706," CA; "Estado de las doctrinas del Uruguay del año de 1715," CA; "Estado de las doctrinas de Paraguay del año de 1716," CA; "Estado de las doctrinas de Paraguay del año de 1717," CA; Jackson, Demographic Change and Ethnic Survival, 248.

134 For demographic patterns on the Jesuit Chaco missions, see Robert H. Jackson, "La población y tasas vitales de las otras misiones jesuíticas de la provincia de Paraguay y Moxos," IHS: Antiguos jesuitas en Iberoamérica 6, no. 1 (January-June 2018): 104-18. 
TABLE 15 The population of Jesús María de los Guenoas mission

\begin{tabular}{llll}
\hline Year & Population & Families & Average family size \\
\hline 1690 & 324 & 74 & $4 \cdot 5$ \\
1693 & 295 & 74 & 4.0 \\
1694 & 298 & 85 & $3 \cdot 5$ \\
1698 & 200 & 80 & $2 \cdot 5$ \\
1700 & 291 & 80 & 3.6 \\
1702 & 200 & 79 & 2.5 \\
1705 & 288 & 87 & 3.0 \\
1706 & 297 & 97 & 3.1 \\
1708 & 303 & 28 & 10.8 \\
1714 & 357 & & 4.2 \\
1715 & 281 & 67 & 3.6 \\
1716 & 307 & 86 & $3 \cdot 3$ \\
1717 & 283 & 85 & $4 \cdot 7$ \\
1719 & 238 & 51 & \\
\hline
\end{tabular}

Source: "ANNUA de las doctrinas del paraná y uRuguay [...] Del año de 1693," CA; "ANNua de las doctrinas del paraná y uruguay [...] Del año de 1694," Ca; "Estado de las REDUCCiOnes del paraná de este AÑo DE 1698," CA; "ANNUA Doctri-

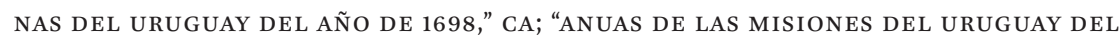
AÑo DE 1700," CA; “ESTADO DE LAS DoctrinAS DEL URUGUAY AL FIN DEL AÑO DE 1705," CA; "Estado de las doctrinas del URUguay Al Fin del año de 1706," CA; "Estado DE las doctrinas del uRuguay del año de 1715," Ca; "Estado de las doctrinas de paraguay del año De 1716," Ca; "ESTAdo de las doctrinas de paraguay del año de 1717," CA; JACKSON, DEMOGRAPHIC CHANGE AND ETHNIC SURVIVAL, 248.

close to Montevideo. ${ }^{135}$ However, most of the Guenoa Minuanos who chose mission life, even if temporarily, settled on the Guaraní missions, and particularly on San Francisco de Borja.

A 1732 document summarizes the numbers of baptisms recorded on San Francisco de Borja between the dates of its establishment in 1687 through 1732. ${ }^{136}$ The summary records baptisms of 402 non-Christian adults that the Jesuits had settled on the mission in the first two decades following the establishment of the mission, and again in the 1720 and 1730 following the merger

135 Bracco, "Guenoa minuano," 37, 39.

136 "Relación de los bautismos del pueblo de San Francisco de Borja, desde el año de su fundación en 1687 hasta el presente año de 1732," cA. 
of the population of Jesús María. The document records the baptism of the children of the recently congregated adults in the list of baptisms of párvulos or children under the age of about ten. The document also notes the baptism of another 1,952 individuals who had settled on Santo Tome and San Francisco de Borja, most if not all of whom were Guenoa Minuanos. This pattern shows that the Jesuits baptized Guenoa Minuanos at both missions, but Jesús María was exclusively a community of Guenoas. The Jesuits continued to congregate Guenoa Minuanos on San Francisco de Borja mission during the rest of their tenure on the mission, although the process of congregation did not always go smoothly. In 1730, for example, forty members of one toldería settled on the mission, but other band members refused to do so following an altercation with another indigenous group that resulted in a number of deaths. However, the band members promised to return to the mission once they had exacted blood revenge on the group they had clashed with. ${ }^{137}$ The residents of Guenoa Minuanos tolderías continued to adhere to their traditional values and way of life.

Guenoa Minuanos constituted a large part of the population of San Francisco de Borja. A 1743 report noted that a third of the people living on the mission were Guenoa Minuanos. ${ }^{138}$ In 1743, the mission had a population of 3,871, and the number of Guenoa Minuanos was between 1,200 and 1,300.

The Jesuits congregated numbers of non-sedentary groups on other missions. During the seventeenth century, for example, the Jesuits congregated Charrúa on Yapeyú mission. In the years $1665^{-66}$, the Jesuits settled some 250 on the mission and five hundred Yaros in 1701 during the campaign against the non-sedentary groups in the Banda Oriental. ${ }^{139}$ There was one baptism of a non-Christian adult there in 1693 and nineteen in 1698. The missionaries stationed on Corpus Christi congregated bands of a non-sedentary group known as Guañanas in 1702, 1724, 1730, and 1754, and in 1759 there were one 112 Guañanas living on the mission in separate cacicazgos in addition to 4,530 Guaraní. ${ }^{140}$ The Jesuits also reported the baptism of small numbers of nonChristian adults at other missions. At Jesús, for example, there were eleven in 1691, thirty-one in 1695, and two in 1702. In 1702, it was ten adults and older children at Loreto, ${ }^{141}$ seven at San Ignacio, and eighteen at San Francisco Xavier in

\footnotetext{
137 Bracco, "Guenoa minuano," 38.

138 Bracco, "Guenoa minuano," 38.

139 Jackson, Demographic Change and Ethnic Survival, 16.

140 Jackson, Demographic Change and Ethnic Survival, 101-2.

141 "Annua del pueblo de Loreto de 1702," CA.
} 
1708. However, San Francisco de Borja most likely had the largest population of non-sedentary groups of the thirty missions among the Guaraní.

Non-sedentary indigenous groups also inhabited the Chaco region west of the Spanish settlements and missions located along the major rivers in the region. The Jesuits established missions among nomadic populations of hunters and gatherers in the Chaco region. The missions generally existed for only short periods of time, as the Jesuits were unable to persuade the nomadic native groups to permanently settle on the missions and change their way of life to become sedentary agriculturalists. ${ }^{142}$ One reason for this, as mentioned earlier, was the reluctance of men to engage in sustained agricultural work. The Jesuits failed to comprehend the logic of the social organization of groups such as the Abipones. Men obtained status from their skills as hunters and warriors, and in their ethos doing work they associated with the proper role of women would have been demeaning and resulted in a loss of status. In the case of the San Fernando de Abipones mission, the Jesuits consequently hired nonAbipones to do routine work on the mission that Abipone men would not do. ${ }^{143}$

In other cases, such as that of San Estebán Lules, the missions occupied multiple sites. Toward the end of the Jesuit tenure on the missions, there was also an expansion in the number of communities. A 1765 document, for example, lists the missionaries stationed on the Chaco missions located on the Tucumán frontier. They included San Estebán Miraflores (Lules), San Juan Bautista Balbuena, Nuestra Señora del Buen Consejo, Nuestra Señora del Pilar Pasaynes y Athulalas, Nuestra Señora de la Paz de Vilelas, San José de Vilelas, San Ignacio de Tobas, and Nuestra Señora de la Concepción de Abipones. ${ }^{144}$ The populations fluctuated as the Jesuits attempted to congregate natives on the missions, and particularly as some men resisted changes to their way of life. The existing censuses also contain summaries of baptisms and burials. As the missions were generally open populations, the calculation of crude birth rates is difficult because of the baptism of people, both adults and children, only recently congregated on the missions. The extant data also shows instability in the Chaco mission populations (see table 16) (see fig. 13; see Map 4).

142 For a general study of the Chaco missions and the social and political organization of the Chaco groups including the Abipones, see James Saeger, The Chaco Mission Frontier: The Guaycuruan Experience (Tucson, AZ: University of Arizona Press, 200o). Also see Carlos Page, Las otras reducciones jesuitas: Emplazamiento territorial, desarrollo urbano y arquitectónico entre los siglos XVII y XVIII (Saarbrücken: Editorial Académico Española, 2012).

143 María Laura Salinas, "San Fernando del Río Negro: Un intento evangelizador jesuítico a los Abipones," Diálogos 13, no. 2 (2009): 293-322.

144 "Padres curas y compañeros de las nuevas reducciones del Chaco en la frontera Tucumán," AGN, Sala IX-6-10-6. 
TABLE 16 The population of the Chaco region mission, in selected years

\begin{tabular}{|c|c|c|c|c|c|c|}
\hline \multirow[t]{2}{*}{ Year } & \multirow{2}{*}{$\begin{array}{l}\text { Rosario } \\
\text { (Chiriguano) }\end{array}$} & \multicolumn{2}{|c|}{ Lules } & \multirow[t]{2}{*}{ Omoampas } & \multirow{2}{*}{$\begin{array}{l}\text { SFX } \\
\text { Mocovíes }\end{array}$} & \multirow{2}{*}{$\begin{array}{l}\text { S Ignacio } \\
\text { Tovas }\end{array}$} \\
\hline & & S Estebán & Concepción & & & \\
\hline 1736 & 160 & & 170 & & & \\
\hline 1745 & 190 & 415 & 172 & & 271 & \\
\hline \multicolumn{7}{|l|}{1753} \\
\hline \multicolumn{7}{|l|}{1754} \\
\hline 1755 & & & & & 826 & \\
\hline \multicolumn{7}{|l|}{$175^{6}$} \\
\hline 1757 & & & & & & 306 \\
\hline $175^{8}$ & & 664 & & & & \\
\hline \multicolumn{7}{|l|}{1759} \\
\hline \multicolumn{7}{|l|}{1760} \\
\hline \multicolumn{7}{|l|}{1761} \\
\hline 1762 & & 703 & & & & 357 \\
\hline 1764 & & & & & 833 & \\
\hline 1765 & & $5^{23}$ & & 180 & & 400 \\
\hline 1766 & & & & 159 & & \\
\hline 1767 & & $5^{18}$ & & & & \\
\hline
\end{tabular}

\begin{tabular}{|c|c|c|c|}
\hline Year & Abipone missions & $\begin{array}{l}\text { S.J.B. } \\
\text { Isistines }\end{array}$ & $\begin{array}{l}\text { Pilar } \\
\text { Pasatines }\end{array}$ \\
\hline
\end{tabular}

S Fernando S Jerónimo Concepción

$\begin{array}{llll}1745 & 300 \\ 175^{1} & & \\ 175^{2} & & 460 \\ 1753 & 679 & & \\ 1754 & 455 & & \\ 1755 & 344 & & \\ 175^{6} & 355 & 591 & \\ 1757 & 363 & & \\ 175^{8} & 151 & & \\ 1759 & 338 & & 694 \\ 1760 & 339 & 570 & \\ 1761 & 273 & & \end{array}$


TABLE 16 The population of the Chaco region mission, in selected years (cont.)

\begin{tabular}{|c|c|c|c|c|c|c|}
\hline \multirow[t]{2}{*}{ Year } & \multicolumn{3}{|c|}{ Abipone missions } & \multirow{2}{*}{$\begin{array}{l}\text { S.J.B. } \\
\text { Isistines }\end{array}$} & \multirow{2}{*}{$\begin{array}{l}\text { Pilar } \\
\text { Pasatines }\end{array}$} & \multirow{2}{*}{$\begin{array}{l}\text { San José } \\
\text { Vilelas }\end{array}$} \\
\hline & S Fernando & S Jerónimo & Concepción & & & \\
\hline 1762 & 284 & $45^{\circ}$ & & 647 & & \\
\hline \multicolumn{7}{|l|}{1764} \\
\hline 1765 & 400 & & 200 & & 159 & 463 \\
\hline 1766 & & & & 737 & 164 & 507 \\
\hline
\end{tabular}

SOURCE: JACKSON, POPULATION HISTORY OF THE MISSIONS OF THE JESUIT PROVINCE OF PARAQUARIA, 281-82.

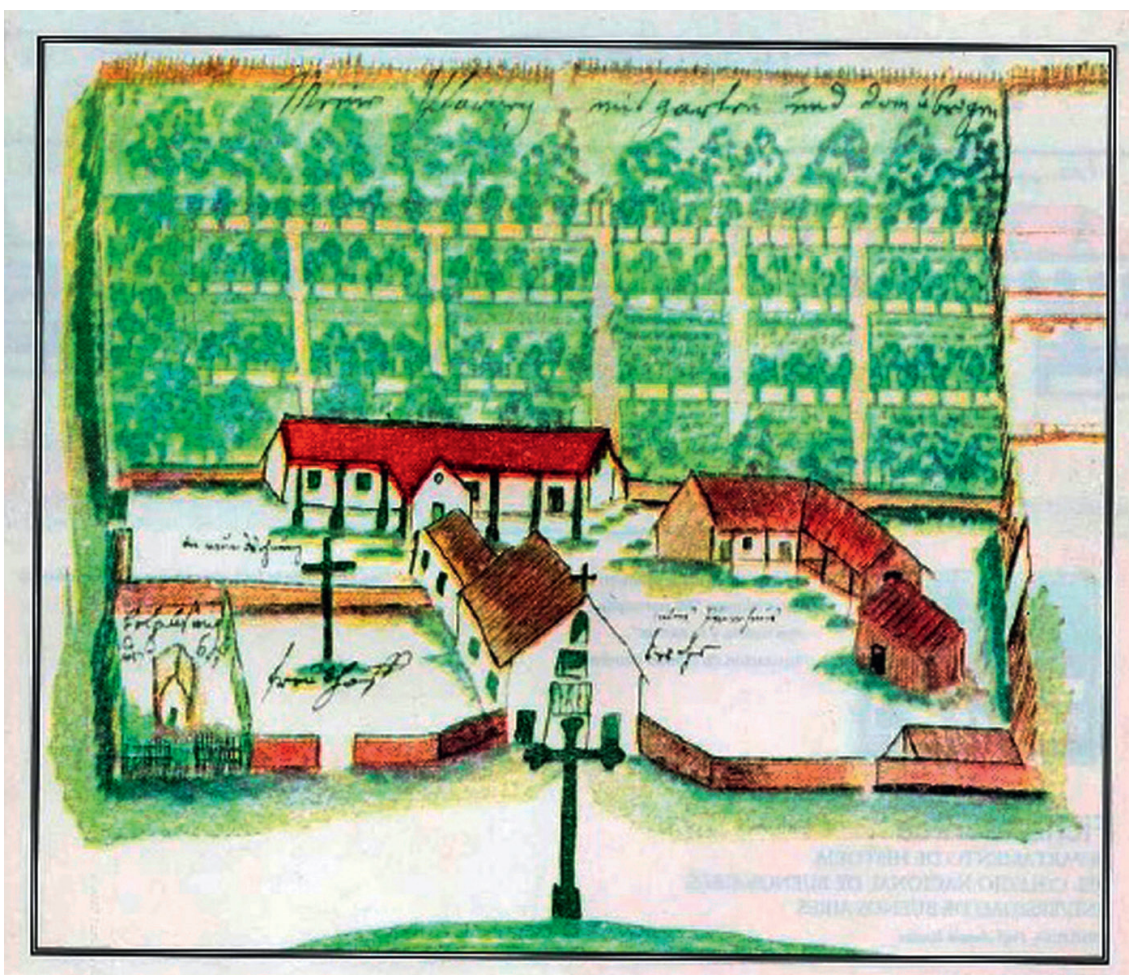

FIGURE 13 A contemporary painting of San Francisco Xavier Mocobíes, which was a typical Chaco mission 


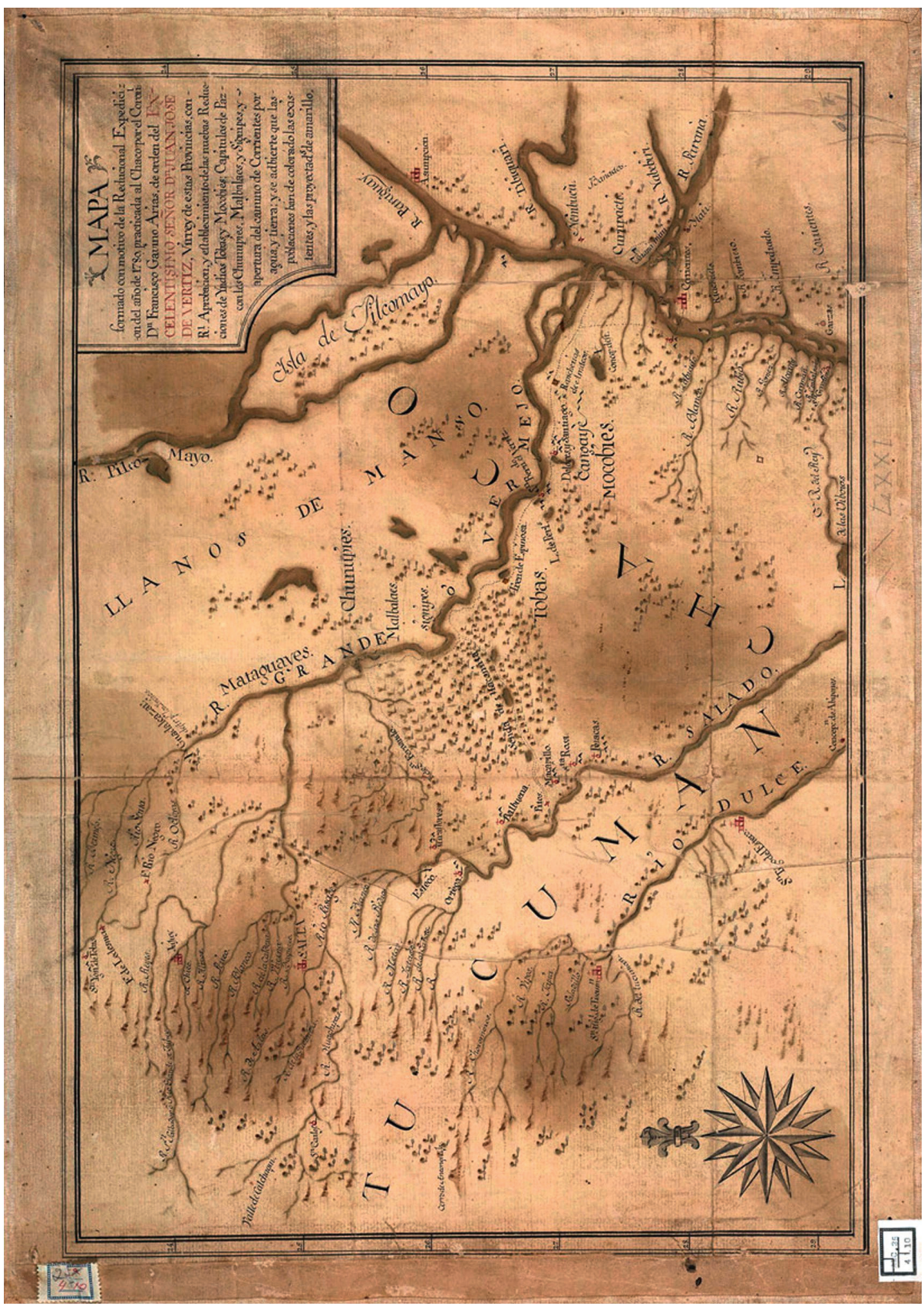

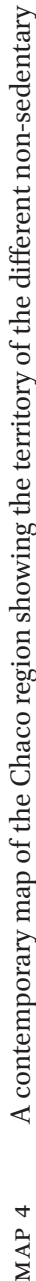


The case of San Fernando de Abipones mission highlights the Jesuit failure to create stable sedentary communities. A census prepared in 1762 recorded baptisms and burials for nearly a decade and included detailed information on demographic trends. The Jesuits established San Fernando de Abipones in 1750 on the western bank of the Río Paraná, opposite Corrientes. Following the Jesuit expulsion, the Franciscans staffed the mission until the beginning of the independence movement in the Río de la Plata region, at which point the Abipones resumed raiding Spanish settlements as they had done before the establishment of the mission. The missionaries ultimately abandoned the mission, thus ending the effort to evangelize the nomadic Chaco groups. ${ }^{145}$

Demographic patterns on San Fernando de Abipones were different from other missions such as the Jesuits' Paraguayan missions. The Jesuits primarily baptized children and very few adults. Those adults who accepted baptism did so only on the point of death. The Jesuits failed to persuade most adults to accept baptism, which would have signified a sea-change in their way of life. The evidence from the 1762 census suggests that the Abipones permitted their children to be baptized, which may have been the one condition the Jesuits could demand in return for admission to the mission community for those who remained even if only for short periods. Few Abipones were buried at the mission, and many adults most likely died away from the mission (see table 17). The evidence contained in the 1762 census shows that most adults rejected the new faith.

An analysis of the age and gender structure of San Fernando de Abipones shows that women and children constituted most of the population, with Abipone men choosing not to reside on the mission. This suggests that the Abipones used the mission as a place of refuge to leave their women, children, and the elderly when they went to hunt or wage war against rival native groups. This practice was similar to that of other indigenous groups, such as the Karankawas of the Texas Gulf Coast. A similar pattern is observed in two censuses of San Jerónimo Abipones in $175^{8}$ and 1762 . The censuses divided the population between those already baptized and those who were unbaptized and were still receiving religious instruction. Women and children constituted the majority of those still unbaptized, or 56.8 percent, whereas it was only 44.9 percent for those already baptized. In 1762 , it was 57.8 percent and 45.1 percent respectively. ${ }^{146}$

145 Saeger, Chaco Mission Frontier, 30, 38-39, 166-67.
146 Jackson, Population History, 195. 
TABLE 17 The population and vital rates of San Fernando de Abipones

\begin{tabular}{|c|c|c|c|c|c|c|c|c|c|}
\hline Year & Population & Families & $\begin{array}{l}\text { Baptisms } \\
\text { Párvulos }\end{array}$ & Adults & $\begin{array}{l}\text { In articulo } \\
\text { mortis (At } \\
\text { the point } \\
\text { of death) }\end{array}$ & Burials & CBR & CDR & $\begin{array}{l}\text { Average } \\
\text { family size } \\
\text { (Estimated) }\end{array}$ \\
\hline 1753 & 679 & $15^{6}$ & 12 & 3 & 1 & 2 & $17 \cdot 9$ & 3.0 & 4.4 \\
\hline 1754 & 455 & 104 & 18 & 2 & o & 5 & 26.5 & $7 \cdot 4$ & 4.4 \\
\hline 1755 & 344 & 80 & 12 & 4 & 3 & 3 & 26.4 & 6.6 & $4 \cdot 3$ \\
\hline $175^{6}$ & 355 & 82 & 8 & o & 1 & 3 & $23 \cdot 3$ & 8.7 & $4 \cdot 3$ \\
\hline 1757 & 363 & 82 & 6 & o & 2 & 4 & 8.5 & 11.3 & 4.4 \\
\hline $175^{8}$ & $15^{1}$ & 39 & 3 & o & 1 & 3 & 8.3 & 8.3 & $3 \cdot 9$ \\
\hline 1759 & 338 & 76 & 9 & $\mathrm{O}$ & $\mathrm{o}$ & 3 & 59.6 & $19 \cdot 9$ & $4 \cdot 5$ \\
\hline 1760 & 339 & 74 & 16 & o & 3 & 3 & 26.6 & 8.9 & 4.6 \\
\hline 1761 & 273 & $5^{6}$ & 10 & 1 & 2 & 2 & $29 \cdot 5$ & 5.0 & 4.9 \\
\hline 1762 & 284 & 48 & 6 & o & o & 2 & 22.0 & $7 \cdot 3$ & $5 \cdot 9$ \\
\hline
\end{tabular}

SOURCE: JACKSON, DEMOGRAPHIC CHANGE AND ETHNIC SURVIVAL, 129.

\subsection{The Baja California Missions}

The Jesuit missions of Baja California founded after 1697 were unique because, as already noted, the Jesuits themselves provided the funding with no royal support. This was because the crown-funded colonization efforts proved to be a costly failure. Cortés organized the first expeditions that explored and attempted to colonize Baja California, but his effort failed because of the hostility of the indigenous peoples and the aridity of the peninsula. Other colonization schemes also failed, and the crown ultimately abandoned its efforts to occupy the peninsula following the closure of the outpost at San Bruno, which operated between 1683 and 1685 . The Jesuit missionary Kino, who later established missions in northern Sonora, attempted to evangelize the local indigenous population. After the failed attempts at colonization, the Jesuits assumed responsibility for establishing missions in Baja California in 1697, but at their own expense. This also allowed the Jesuits to control the selection of nonmissionary personnel that came into the peninsula and contacts with Sinaloa and Sonora on the mainland.

The practice was that a mission would not be founded until an endowment generally set at ten thousand pesos existed to pay the costs of a new mission. The Jesuits invested the amount of the endowment in income-producing 
properties with the goal of generating five hundred pesos per year in income. Juan Bautista Luyando (1700-55), for example, donated ten thousand pesos to establish the San Ignacio mission in 1728 and served as the first missionary. ${ }^{147}$ The Jesuits found different ways to make ends meet on the peninsula missions. In the years 1742-44, for example, Joseph Gasteiger (1702-54), stationed on Guadalupe mission, used 1,76o pesos in funds from the endowment to purchase supplies through the royal treasury office in Loreto. He also bartered for an additional 1,440 pesos in supplies and sold 266 pesos worth of produce to the San Ignacio mission. ${ }^{148}$ The Jesuit missions in Sinaloa, Sonora, and the Tarahumara region also shipped food and other supplies to Baja California. One report noted that between 1697 and 1720, these missions shipped supplies to Baja California reportedly worth 105,00o pesos. ${ }^{149}$

Even with the provision of supplies from the other missions and because of the aridity of much of the peninsula and the limitations to agricultural production, the Jesuits were unable to congregate all of the neophytes in a single community. Instead, they implemented a system based on a dispersed settlement pattern. In 1720, for example, the population of Guadalupe mission (established in 1720) totaled two thousand and six years later in 1726 reportedly was 1,707 living in thirty-two rancherias. ${ }^{150}$ The case of the two missions established among the group collectively known as the Guaycuros also typified the Jesuit system. In 1721, Clemente Guillen (1677-1748) established the first mission among the Guaycuros under the designation of Nuestra Señora de los Dolores, and in 1737 the Jesuits established San Luis Gonzaga. Guillen reported that it took him some twenty years to finally congregate the natives to a group of six settlements he identified as pueblos, which meant that they were different from the seasonally shifting native settlements. In 1744, the six villages were known as Dolores, the main mission village, with a population of 159; Limpia Concepción with a population of 124; Encarnación, which counted 112 neophytes; Trinidad with eighty-two; Redención with 130; and Resurreción counting 142. The neighboring mission of San Luis Gonzaga consisted of three villages: San Luis Gonzaga with 190 neophytes, Santa María Magdalena with 195, and San Juan Nepomuceno with 131 neophytes. Guillen also reported he had organized a village named Jesus María to the west near Magdalena Bay with 159 natives, and another fifty-six he hoped to settle at Jesús María. Because of the distance of the village from both Dolores and San Luis Gonzaga,

\footnotetext{
147 Jackson, Missions and the Frontiers of Spanish America, 114-15.

148 Jackson, Missions and the Frontiers of Spanish America, 115.

149 Jackson, Missions and the Frontiers of Spanish America, 122.

150 Robert H. Jackson, "Demographic Patterns in the Missions of Central Baja California," Journal of California and Great Basin Anthropology 6 (1984): 91-112, here 102.
} 
the Jesuits hoped to establish another mission for these groups. Guillen noted that he had to visit caves and go into the nearby mountains to look for the natives. Once brought under the mission's sphere of influence, the Jesuits periodically brought the natives to the main mission village to receive religious instruction. ${ }^{151}$ The population of Dolores del Sur and San Luis Gonzaga totaled one thousand and 516 respectively in 1744, but this number had dropped to 458 and 288 twenty-four years later, in 1768 .

The San José de Comondú mission provides a second example of patterns of development during the Jesuit tenure. The Jesuits founded the mission in 1708 at a site known today as Comondú Viejo once they had an endowment of ten thousand pesos to cover the costs of its administration. The Jesuits operated the mission at the site for twenty-eight or twenty-nine years, and there are still ruins of a small church and other structures. They relocated the mission in 1736 or 1737 to a valley to the south that had a more reliable water supply, which had been a visita of the Loreto mission known as San Ignacio. Juan María Salvatierra (1648-17) developed the site at San Ignacio because of its agricultural potential. A second visita named San Miguel Cadandogomo existed at a site in the same valley several miles away. Juan de Ugarte (1662-30), stationed in San Francisco Xavier, founded the visita in 1714. He had the site populated and a dam and irrigation system constructed.

In the first decades of the eighteenth century and as the Jesuits expanded the number of missions, the indigenous population declined. At the same time, disease decimated the mission populations. A series of individual reports drafted in 1744 provide a reckoning of sorts of population decline. The reports record the total number of baptisms registered from the date of the founding of the missions to the point of the report and the population, which enables an estimate of the degree of depopulation. The Jesuits had recorded 14,830 baptisms at the eight missions for which reports exist, and the population totaled 4,222 , indicating a decline in the population in the range of seventy-two percent from levels when the Jesuits founded the first mission in 1697 (see table 18). The record shows, however, that the populations of several missions stabilized and experienced growth following several decades of decline. A 1762 report on San Francisco Xavier (founded 1699) notes that the Jesuits had baptized 448 and recorded 357 burials between 1745 and the drafting of the report. The population grew from $35^{2}$ in 1744 to 482 in 1768 . The population of Guadalupe mission (founded 1720) also grew during the same period. It totaled 701 in 1744, dropped to 472 in 1755 , and then increased to 544 in 1768 (see table 19).

$15^{1}$ Clemente Guillen, "Informe del principio, progresso, y estado presente de la mission de Nra. Senora de los Dolores," 1744, Bancroft Library, University of California, Berkeley. 
TABLE 18 Population of the Baja California missions in 1744 and total baptisms from date of foundation to 1744

\begin{tabular}{lllc} 
Mission & Year founded & Baptisms to $\mathbf{1 7 4 4}$ & Population in $\mathbf{1 7 4 4}$ \\
\hline Loreto & 1697 & 1,199 & 150 \\
San Francisco Xavier & 1699 & 1,726 & $35^{2}$ \\
Mulegé & 1705 & 1,358 & 326 \\
Comondú & 1708 & 1,563 & 513 \\
La Purísima & 1718 & 1,890 & 535 \\
Guadalupe & 1720 & 2,599 & 701 \\
Santiago & 1721 & 1,749 & 440 \\
San Ignacio & 1728 & 2,746 & 1,196 \\
\hline
\end{tabular}

SOURCE: JACKSON, INDIAN POPULATION DECLINE, 58.

TABLE 19 The population of San Francisco Xavier and Nuestra Señora de Guadalupe missions, in selected years

\begin{tabular}{|c|c|c|c|c|c|c|}
\hline \multicolumn{2}{|c|}{$\begin{array}{l}\text { San Francisco } \\
\text { Xavier }\end{array}$} & \multirow[t]{2}{*}{$\begin{array}{l}\text { Baptisms } \\
1699^{-1761}\end{array}$} & \multirow[t]{2}{*}{$\begin{array}{l}\text { Burials } \\
1745^{-62}\end{array}$} & \multicolumn{2}{|c|}{ Guadalupe } & \multirow[t]{2}{*}{$\begin{array}{l}\text { Baptisms reported } \\
1720-44\end{array}$} \\
\hline Year & Population & & & Year & Population & \\
\hline 1744 & $35^{2}$ & 2,174 & 357 & 1744 & 701 & 2,599 \\
\hline 1755 & 380 & & & 1755 & 472 & \\
\hline 1762 & 448 & & & 1762 & $5^{24}$ & \\
\hline 1768 & 482 & & & 1768 & 544 & \\
\hline 1771 & 212 & & & 1771 & 140 & \\
\hline 1773 & 279 & & & 1773 & 176 & \\
\hline 1774 & 275 & & & 1774 & 105 & \\
\hline 1782 & 169 & & & 1782 & & \\
\hline
\end{tabular}

SOURCE: ROBERT H. JACKSON, "DEMOGRAPHIC PATTERNS IN THE MISSIONS OF CENTRAL BAJA CALIFORNIA," JOURNAL OF CALIFORNIA AND GREAT BASIN ANTHROPOLOGY 6, NO. 1 (1984): 91-112. 
The Comondú mission provides another detailed record of demographic patterns during the Jesuit tenure. Following the formation of the mission community and visitas, the population of Comondú mission slowly declined. The 1744 report on Comondú noted a population of 513 and that the Jesuits had baptized 1,563 between 1708 and 1744. A complete set of baptismal and burial registers survives for the years 1737-1806. The Jesuits generally did not record enough detailed information in baptismal entries to distinguish between the baptisms of newborn children or non-Christians congregated on the mission, but the records do show a declining trend. Between 1737 and 1767 , the Jesuits recorded 798 baptisms and 852 burials, or a net difference of fifty-four. ${ }^{152}$ The mission population dropped to 330 in 1768.153

In the 1740 s and 1750 s, the Jesuits initiated major construction projects at a number of mission sites including Loreto, San Francisco Xavier, Mulegé, and Comondú. The Jesuits directed the construction of the first church at Loreto mission between 1699 and 1704. It was built of adobe and measured fifty-five by seventeen feet. There was a colegio consisting of two wings that each measured fifty-five feet in length and contained a residence for the Jesuits and a dormitory for single women who were to be segregated from the general population. The neophyte population lived in two rows of small adobe apartments enclosed by walls. In 1740, construction began on a new stone church that took a decade to build. It measured 150 by twenty feet, and was the longest church on the peninsula missions. The Jesuits also directed the construction of a new and larger residence for themselves. ${ }^{154}$

The Jesuits also directed the construction of a new and larger church at Comondú. The construction of the three-nave stone church with vaulted roof took six years from 1754 to 176 o. A 1793 report described the church as having dimensions of thirty by thirteen varas, or 25.1 by 10.8 meters; it had three entrances and the same number of altars. Other buildings in the complex described in a 1773 inventory include several granaries and store rooms, a forge, weaving room, tack room, and shoe shop. The residence of the missionaries was spacious and was also built of stone. The neophyte population most likely lived in traditional housing. This changed following the Jesuits' expulsion (see fig. 14).

In the last two decades of their tenure in the peninsula missions, the Jesuits expanded missions into one of the most arid regions of Baja California, the area

\footnotetext{
$15^{2}$ San José de Comondú Baptismal and Burial Registers, Asociación Histórica Americanista, Mexico City.

153 Jackson, "Demographic Patterns," 100.

154 Jackson, Missions and the Frontiers, 195.
} 


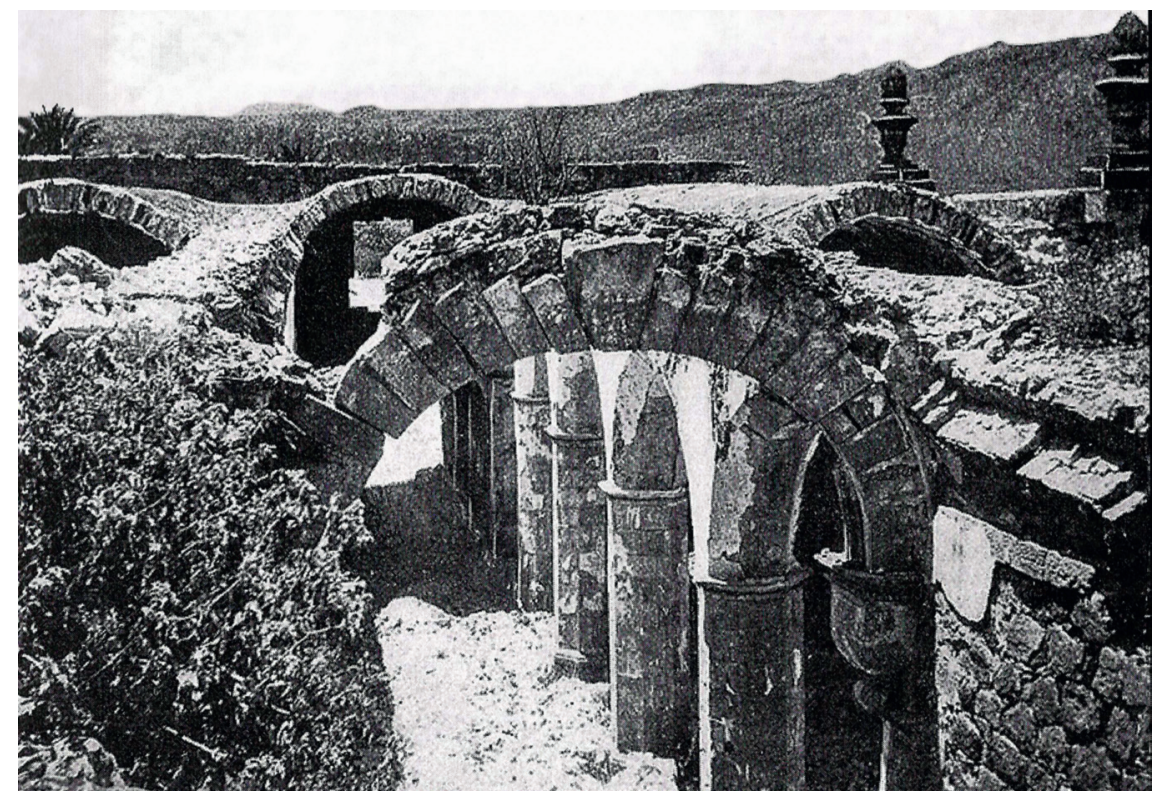

FIGURE 14 A historic photograph of the ruins of the church at Comondú

known as the Central Desert. The first was Santa Gertrudis la Magna. Although the date conventionally given for its foundation is $175^{2}$, the baptismal register has the date of 1751. The Croat Fernan Konsag had been at San Ignacio mission for about a decade making the preparations for the new establishment and exploring the region to find a suitable site. The San Ignacio baptismal register contains the baptisms of hundreds of neophytes later transferred to the jurisdiction of the new mission. Because of the limited potential for agriculture at the mission site, most of the neophytes continued to reside in their settlements and fended for themselves. In 1755, Santa Gertrudis had a population of 1,586, which rose to 1,730 in 1762 before falling to 1,36 o in 1768 . In 1762 , the Bohemian Jesuit Wenceslao Linck founded the San Francisco de Borja mission at a site known as Adac. In 1768, the mission had a population of 1,640 in a dispersed settlement pattern. The final mission was Santa María de los Ángeles, which was founded in 1766 at a site known as Calamajué but later relocated to another site. ${ }^{155}$

155 Jackson, “Demographic Patterns." 


\subsection{Conclusions}

The Jesuit efforts to congregate and evangelize non-sedentary indigenous peoples had mixed results. The Río de la Plata region was a borderland disputed over two centuries by Spain and Portugal, and until the 1770s Spain invested limited resources in its subjugation. It was an open frontier, and Spain effectively controlled a small part of the region. The non-sedentary peoples could negotiate with the Spanish or Portuguese, or could disappear into parts of the frontier beyond Spanish control. It was only in the late eighteenth and nineteenth centuries that Spain and the nation-states that emerged following the beginning of the independence movement after 1810 finally subjugated the non-sedentary groups. In some cases, the non-sedentary indigenous groups used the Jesuit missions as places of refuge.

At the point of the Jesuit expulsion in 1768, there were fifteen missions in Baja California with a total population of 7,149 , or an average of 470 per mission. This is the highest recorded population. ${ }^{156}$ Because of the limited ability to produce food, and despite shipments of grain from Sinaloa, Sonora, and the Tarahumara missions, the Jesuits could not congregate the entire indigenous populations on one community as had been done in the missions among the sedentary populations of Paraquaria. The neophytes lived in their traditional settlements and largely fended for themselves with minimal Jesuit supervision. The Jesuits brought them to the main mission periodically for religious instruction but then left them to their own devices. The process of conversion was slow and superficial at best. Non-sedentary indigenous populations, particularly those in Baja California, also proved to be more demographically fragile than sedentary populations.

For some two hundred years, the Society of Jesus played an important social, economic, and political role in Spanish America, but the Jesuits also had their detractors. The European world of the mid-eighteenth century was very different from that of the sixteenth century when the order came into existence. The Treaty of Westphalia (1648) negotiated to end the Thirty Years' War (161848) effectively ended a century of armed religious conflict between Catholics and Protestants, and the Counter-Reformation wound down. Reformist monarchs and their ministers sought to expand state power, and an international

${ }_{15} 6$ Jackson, Indian Population Decline, 59. 
organization such as the Society of Jesus was an obstacle to that. The other religious orders had national-level organizations in each country and were therefore less suspect. There were multiple political and economic motives for the decision to expel the Jesuits. The first country to do so was Portugal in 1759, with France following in 1764. Carlos III signed the expulsion decree on February 27, 1767 but chose not to give the reasons for his decision. Royal officials were to open and implement the decree on June 24, 1767.157 Eventually, some ten thousand Jesuits were exiled from Spanish territory to Bologna and neighboring communities in Italy. ${ }^{158}$

Although not the proximate cause for the decision to expel the Jesuits, the so-called Bourbon reforms provide the context. In 1700, King Carlos II (16611700, r.1665-1700) died without an heir, and there were two rival claimants to the throne. A long war decided between the two, and a grandson of Louis XIV of France $(1638-1715$, r.1643-1715) became the new king. The Bourbon monarchs of French descent began tinkering with the Habsburg colonial system in the first half of the eighteenth century in order to enhance royal authority and rationalize the inefficient and decentralized Habsburg colonial system, which had its origins in late medieval notions of political and economic organization. However, the reform impulse accelerated as a consequence of military defeat in the Seven Years' War.

European conflict in the late seventeenth and eighteenth centuries spilled over into European colonial territories in the Americas, Africa, and Asia. Certain areas in the Americas, for example, became focal points of conflict. The Caribbean Basin was one. Spanish colonial commerce passed through the region, and the flotas (convoys of merchant ships) became the target of Spain's European rivals as well as the buccaneers, a conglomeration of people of different nationalities that engaged in piracy. Spain responded to the threat to its commerce by building massive stone fortifications to protect its ports, a strategy that proved flawed when the British simultaneously occupied Havana and Manila in 1762 during the Seven Years' War. ${ }^{159}$ A failed British assault on Cartagena in 1741 had temporarily reaffirmed Spanish confidence in this defensive strategy, but it was disease rather than Spanish defenses that defeated the

157 Alma Montero Alarcón, Jesuitas de Tepotzotlán: La expulsión y el amargo destierro (Mexico City: INAH, 2014), 44.

158 Montero Alarcón, Jesuitas de Tepotzotlán, 105.

159 David Greentree, A Far-Flung Gamble: Havana 1762 (London: Osprey, 2010); Nicholas Tracy; Manila Ransomed: The British Assault on Manila in the Seven Years War (Exeter: University of Exeter Press, 1995). 
British attack. ${ }^{160}$ The Spanish defeat in the war, however, resulted in a military reorganization in Spanish America and the creation of the first standing armies, which had to be funded. The military reorganization was a key element of the so-called Bourbon Reforms in Spanish America after $1762 .{ }^{161}$ Administrative reform attempted to make the collection of taxes more efficient, and the Bourbons also promoted the economic development of some regions with the objective of being able to collect more taxes.

Influenced by Enlightenment ideas, increasingly anticlerical royal officials began questioning the role of the Catholic Church in the economy and politics and criticized the institution of the mission as retarding the integration of natives into colonial society. The Franciscan missions established in the Sierra Gorda in 1744 saw the implementation of a new model for frontier missions in line with Bourbon reformism. The evangelization of the Sierra Gorda started in the 153 os and 1540 s and continued up until the end of the colonial period in the early nineteenth century. Despite efforts to change their way of life, the Pames and Jonaces frequently resisted or at best settled on missions only for short periods of time. The crown commissioned José de Escandón (1700-70) to colonize the region in northeastern New Spain that he called Nuevo Santander, and he implemented a model designed to accelerate and complete the process of the integration of the Pames and Jonaces that inhabited the Sierra Gorda region. In a detailed report drafted in 1743, Escandón strongly criticized what he saw as the failure of some two hundred years of Augustinian missions in the region. He decided to assign Franciscans from the apostolic colleges of San Fernando (Mexico City) and Pachuca to the missions with a mandate to get the job done. ${ }^{162}$

Escandón's critique of the Augustinians called for a new approach to evangelization that implied greater social control of the Pames and Jonaces. The handful of existing reports on the missions provide clues to the methods used, methods that the same group of Franciscans later employed when they

16o Charles E. Nowell, "The Defense of Cartagena," Hispanic American Historical Review 42, no. 4 (1962): 477-5o1; Julián de Zulueta, "Health and Military Factors in Vernon's Failure at Cartagena," Mariner's Mirror 78, no. 2 (1992): 127-41.

161 Leon G. Campbell, The Military and Society in Colonial Peru, 1750-1810 (Philadelphia: American Philosophical Society, 1978); Christon Archer, The Army in Bourbon Mexico, 1760-1810 (Albuquerque: University of New Mexico Press, 1977); Allan J. Kuethe, Military Reform and Society in New Granada, 1773-1808 (Gainesville: University Presses of Florida, 1978); Allan J. Kuethe and Kenneth J. Andrien, The Spanish Atlantic World in the Eighteenth Century: War and the Bourbon Reforms, 1713-1796 (Cambridge: Cambridge University Press, 2014); Jacques A. Barbier, Reform and Politics in Bourbon Chile, 1755-1796 (Ottawa: University of Ottawa Press, 1980).

162 See Jackson, Frontiers of Evangelization. 
assumed responsibility for the former Jesuit missions in Baja California in 1768 and on the California missions established after 1769. The Franciscans placed greater emphasis on promoting the economic dependence of the Pames and Jonaces, which was also seen as the key to keeping the natives congregated on the missions. The Franciscans attempted to transform the natives into sedentary agriculturalists and required them to work on communal projects that involved agriculture, tending livestock, and building projects. The Franciscans also assigned the individual heads of households individual subsistence plots where they reportedly grew corn and frijol for their own subsistence. ${ }^{163}$ The Franciscans had communal crops stored in a granary under their control and distributed a daily food ration. ${ }^{164}$ The purpose of the food ration was to prevent the Pames from leaving in search of food and to enhance economic dependence on the missions.

The new mission model influenced policy implemented on former Jesuit missions along the lines of the Bourbon reform initiatives to accelerate integration of indigenous peoples, particularly non-sedentary indigenous peoples, in a cost-effective way. Two policies implemented by José de Gálvez (1720-87) on the Baja California missions following the Jesuit expulsion attempted to make the missions more efficient but had the unwanted consequence of accelerating the cycle of demographic collapse. The first was the shifting of populations between missions to increase the labor available at missions with greater agricultural potential. ${ }^{165}$ This was an effort to make the missions as self-sufficient as possible in line with the Bourbon initiative to make colonial administration cost-effective and was similar in intent to the policies of the civil administration on the Paraguay missions. Gálvez had people transferred from San Francisco Xavier to Loreto and San José del Cabo and from Guadalupe to La Purísima and Comondú. He also ordered the suppression of Dolores and San Luis Gonzaga missions, and the transfer of the Guaycuros from these two missions to Todos Santos mission, which had greater agricultural potential but only a small native population. The Guaycuros had experienced minimal change in their way of

163 José Ortés de Velasco, O.F.M., to Juan Figueras, O.F.M., Querétaro, December 5, 1746, in Lino Gómez Canedo, Sierra Gorda: Un típico enclave misional en el centro de México (siglos xvii y xviii) (Querétaro: Dirección de Patrimonio Cultural, Secretaría de Cultura y Bienestar Social del Estado de Querétaro, 1988), 213.

164 The series of reports on the missions from $175^{8}$ described this practice. See, for example, Joachín Fernández, O.F.M., Concá, October 11, 1758, "Razón del estado que ha tenido y tiene esta missión del glorioso principe Señor San Miguel de Concá," in Gómez Canedo, Sierra Gorda, 225.

165 Robert H. Jackson, "The Guaycuros, Jesuit and Franciscan Missionaries, and José de Gálvez: The Failure of Spanish Policy in Baja California," Memoria americana 12 (2004): 221-33; Jackson, “Demographic Patterns," 91-112. 
life under the Jesuits, but Gálvez expected them to become a disciplined agricultural labor force overnight. The Guaycuros resisted the imposition of a new labor regime, and Gálvez ended up hiring non-indigenous laborers to work the Todos Santos lands. The second was the colonization of Alta California in 1769, which required the movement of more people from the mainland through the peninsula and resulted in the spread of contagion. One contemporary account, for example, notes that a group of colonists bound for Alta California in early 1781 to colonize Los Ángeles carried smallpox into the peninsula. ${ }^{166}$ With the increased movement of people, disease spread through the missions between 1769 and $1781-82$, killing hundreds.

A detailed document drafted in June of 1769 reported the number of Jesuits exiled from the Indies who arrived in the port of Santa María near Cadiz in Spain for their eventual exile in Italy. The list contains the names of most but not all of the Jesuits expelled from the Indies and does not include those from the Philippines. A total of 2,116 left the Americas, but thirty-eight Jesuits died at sea; 2,078 reached Spain, where another thirty-six died (see table 20). The largest number came from Mexico with 553, but the second largest group was 449 from Paraquaria, which again highlights the importance of the Jesuit missions in the region.

Two examples illustrate the process of expelling the Jesuits. Royal officials in Mexico City opened the expulsion decree on June 24, 1767. The following morning, officials arrived at the novitiate at Tepotzotlán north of the city. At the time, there were seventy-six Jesuits there, including thirty-six novices. The novices were given twenty-four hours to decide if they would remain in the order, or leave. All of the novices chose to remain in the order. On July 4, the group from Tepotzotlán left for Veracruz and on November 21 boarded ships for Europe. There were sixteen Jesuits in the colegio in Zacatecas. ${ }^{167}$ Altogether, the decree exiled 678 Jesuits in Mexico and its dependencies, which included Guatemala and Cuba (see table 20). Of this number, thirty-four died of yellow fever in Veracruz, another nineteen died in Cuba, eleven died at sea, and another nine died in Spain. ${ }^{168}$ In Guanajuato, the expulsion sparked an urban uprising in July 1767 that was brutally suppressed. ${ }^{169}$

The process of exiling the Jesuits in Paraquaria in South America was more complicated, in part because a decade earlier the Guaraní living on the

166 Robert H. Jackson, "The 1781-1782 Smallpox Epidemic in Baja California," Journal of California and Great Basin Anthropology 3, no. 1 (1981): 138-43.

167 Recéndez Guerrero, Legado de la Compañía de Jesús, 102.

168 Montero Alarcón, Jesuitas de Tepotzotlán, 65-67, 86, 103-4.

169 Carlos Ruiz Medrano, "El tumulto de 1767 en Guanajuato," Estudios de historia novohispana 19 (1999): 13-46. 
TABLE 20 The number of Jesuits exiled from the Indies who arrived in the port of Santa María (Spain)

\begin{tabular}{lr} 
Province & Number of Jesuits who arrived \\
\hline Nueva Granada & 204 \\
Peru & 406 \\
Chile & 302 \\
Paraguay & 449 \\
México & 553 \\
Quito & 202 \\
Total sailed & 2,116 \\
Died at sea & 38 \\
Total arrived & 2,078 \\
Died in Santa María & 36
\end{tabular}

SOURCE: FRANCISCO URUBURU DE TORO, JUNE 30, 1769, "LISTA DE LOS JESUITAS EXPULSADOS DE INDIAS, LLEGADOS AL PUERTO DE SANTA MARÍA," BIBLIOTECA NACIONAL DE ESPAÑA, MADRID.

missions located east of the Uruguay River rose in rebellion over plans to transfer the mission territory to Portugal under the terms of the Treaty of Madrid. There were some four hundred Jesuits in the region, including eighty on the missions among the Guaraní, sixteen from the missions of Chiquitania in what now is eastern Bolivia, and twenty-six from the Chaco missions. Of the eighty exiled from the Guaraní missions, twelve died at sea and another nine died in Spain. A total of fifty-nine survived to go into exile. ${ }^{170}$ The governor of Buenos Aires, Francisco de Paula Bucareli y Ursúa (1708-8o, in office 1766-70), personally oversaw the expulsion process, which took longer because of the time lag in the reception of the decree and the distances the governor had to cover, and he wanted to go in person in case of resistance to the removal of the Black Robes. For example, Bucareli y Ursua visited the missions among the Guaraní in July and August of $1768 .{ }^{171} \mathrm{He}$ had previously arrested the Jesuits in major urban centers such as Buenos Aires. A 1768 document listed the group of Jesuits sent to Europe on the frigate Esmeralda and whether they had been

170 Francisco Uruburu de Toro, June 30, 1769, "Lista de los jesuitas expulsados de Indias, llegados al Puerto de Santa María," Biblioteca Nacional de España, Madrid; Guillermo Wilde, Religión y poder en las misiones de Guaraníes (Buenos Aires: Editorial Sb, 2009), 184-85.

171 Wilde, Religión y poder, 191-92. 
TABLE 21 The Jesuits slated to sail to Europe from Buenos Aires on the frigate Esmeralda and their assignments at the time of the expulsion decree

\begin{tabular}{lrl}
\hline Jurisdiction & Colegio & Missions \\
\hline Paraguay & 19 & 6 \\
Corrientes & 3 & 0 \\
Santa Fe & 2 & 6 \\
Salta & 16 & 19 \\
Santiago de Estero & 14 & 0 \\
Valle de Catamarca & 6 & \\
Tucumán & 13 & 0 \\
Rioja & 8 & 0 \\
San Juan & 10 & 0 \\
San Luis & 3 & 0 \\
Mendoza & 8 & 0 \\
Tarija & 12 & 0 \\
Córdoba & 3 & 0 \\
Potosí & 4 & 0 \\
Buenos Aires & 1 & 0 \\
& & \\
\hline
\end{tabular}

SOURCE: FRANCISCO DE PAULA BUCARELI Y URSUA, BUENOS AIRES, MARCH 17, 1768, "Pie de lista de los Regulares del or[DE]N de la compañía de Jesús Que SE CONDUCEN AL bordo DE LA FRAGATA DE GUERRA NOMBRADA LA ESMERALDA [...]," CA.

stationed on the colegios or missions (see table 21). ${ }^{172}$ One hundred were initially slated for the sailing, one died en route, and three joined the group later.

The challenge that royal officials next faced was to find replacements for the Jesuits on the scores of missions they had administered. In Paraquaria, for example, missionaries from different orders replaced the Jesuits but in a new scheme of a civil administration that sought to comply with the Bourbon imperative to make missions cost-effective. The missionaries attended to the sacraments while civil administrators controlled the communal mission economy that the Jesuits had previously overseen and sought to generate revenues to pay the costs of administration. Franciscans, Dominicans, and Mercedarians replaced the Jesuits on the missions among the Guaraní (see table 22). On the

172 Francisco de Paula Bucareli y Ursua, Buenos Aires, March 17, 1768, "Pie de lista de los regulares del Or[de]n de la Compañía de Jesús que se conducen al bordo de la fragata de guerra nombrada la Esmeralda [...]," CA. 
TABLE 22 Missions assigned to the orders that replaced the Jesuits on the missions among the Guaraní

\begin{tabular}{lll}
\hline Franciscans & Dominicans & Mercedarians \\
\hline Santa Rosa & Santos Cosme y Damián & La Fe \\
Jesús & Trinidad & San Ignacio Guazú \\
Ytapúa & San Ignacio Miní & Santiago \\
Santa Ana & San Carlos & Corpus Christi \\
Concepción & Los Santos Mártires del Japón & Loreto \\
San Francisco Xavier & Los Reyes Yapeyú & Candelaria \\
La Cruz & San Francisco de Borja & Apóstoles \\
San José & San Miguel & Santa María la Mayor \\
San Luis Gonzaga & San Nicolás & Santo Tomé \\
San Juan Bautista & & San Lorenzo \\
& & Santo Ángel Custodio \\
\hline
\end{tabular}

SOURCE: GUILLERMO WILDE, RELIGIÓN Y PODER EN LAS MISIONES DE GUARANÍES

(BUENOS AIRES: EDITORIAL SB, 2009), 231.

northern frontier of New Spain, royal officials scrambled to find replacements for the Jesuits and relied primarily on Franciscans from several apostolic colleges. Franciscans from the province of Xalisco and the apostolic college of Santa Cruz in Querétaro staffed the Sonora missions that were not secularized or turned over to the jurisdiction of secular clergy. Franciscans from the apostolic college of San Fernando in Mexico City replaced the Jesuits on the Baja California missions. At the time of the expulsion, they staffed the five missions located in the Sierra Gorda region of Querétaro but chose to turn these missions over to the secular clergy in order to be able to staff the Baja California missions. This was done in 1770. The Fernandinos remained on the Baja California missions for five years (1768-73) and then turned them over to Dominicans in order to be able to expand the newly established mission frontier in Alta California. ${ }^{173}$

The replacements continued to staff the former Jesuit missions into the first decades of the nineteenth century. In the case of the former missions among the Guaraní, the demise of the communities occurred in the years 1810-30 during the process of independence among the former Spanish territories

173 Robert H. Jackson, Pames, Jonaces, and Franciscans in the Sierra Gorda: Mecos and Missionaries (Newcastle upon Tyne: Cambridge Scholars Publishing, 2017), 73-74, 135. 
and competition over territory. The region located between the Paraná and Uruguay Rivers became a war zone, particularly in 1817 and 1818 as a result of a Luso-Brazilian and Paraguayan invasion. In April 1818, for example, a three-day battle at San Carlos left the former mission a ruin (see fig. 15). Archaeological excavations of los Santos Mártires del Japón provided evidence of the burning of the church, which most likely was done by Luso-Brazilians in $1817 .{ }^{174}$ Marauding armies also seized mission residents as captives. The Chiquitos missions, on the other hand, continued to exist as stable communities long after the Jesuit expulsion, and in some cases to the present. ${ }^{175}$

The former Jesuit missions on the north Mexican frontier were a different story. The formal end of the missions occurred in the years immediately following Mexican independence in 1821. Anti-Spanish policies in the late 1820s made it difficult for the Franciscans and Dominicans to find personnel, and an 1833 liberal law mandated the secularization of the existing missions. However, the missions declined as the indigenous populations faced demographic collapse. On the Baja California missions, for example, the population dropped to 2,815 in 1804 , or a mean of 156 per mission. By the 1820 s, there were only a handful of Dominican missionaries left in the peninsula. The same occurred on the Pimería Alta missions in northern Sonora. In 1820, the population of fourteen mission villages was 1,127, or a mean of eighty-one per village. ${ }^{176}$ In both cases, the surviving indigenous populations were increasingly marginalized by a growing number of settlers who came to control land and water rights. The passage of the 1833 secularization law only hastened the process of marginalization.

The Jesuit urban complexes passed into the hands of others, and the crown confiscated income-producing properties and Jesuit funds, including the fund the Jesuits created to finance the Baja California missions, which was generally known as the "Pious Fund," and used the money to help pay the costs of the colonization of Alta California after 1769. The status of the fund following the US occupation of California during the Mexican-American War (1846-48) was only resolved in the international court in The Hague in 1902.

\footnotetext{
174 Robert H. Jackson, Regional Conflict and Demographic Patterns among the Guarani in the Seventeenth and Eighteenth Centuries (Leiden: Brill, 2019), 56-61.

175 Robert H. Jackson, Demographic Change and Ethnic Survival among the Sedentary Populations in the Jesuit Mission Frontiers of Spanish South America, 1609-1803: The Formation and Persistence of Mission Communities in a Comparative Context (Leiden: Brill, 2015), 180 .

176 Robert H. Jackson, Indian Population Decline: The Missions of Northwestern New Spain, 1687-1840 (Albuquerque: University of New Mexico Press, 1994), 57-59.
} 


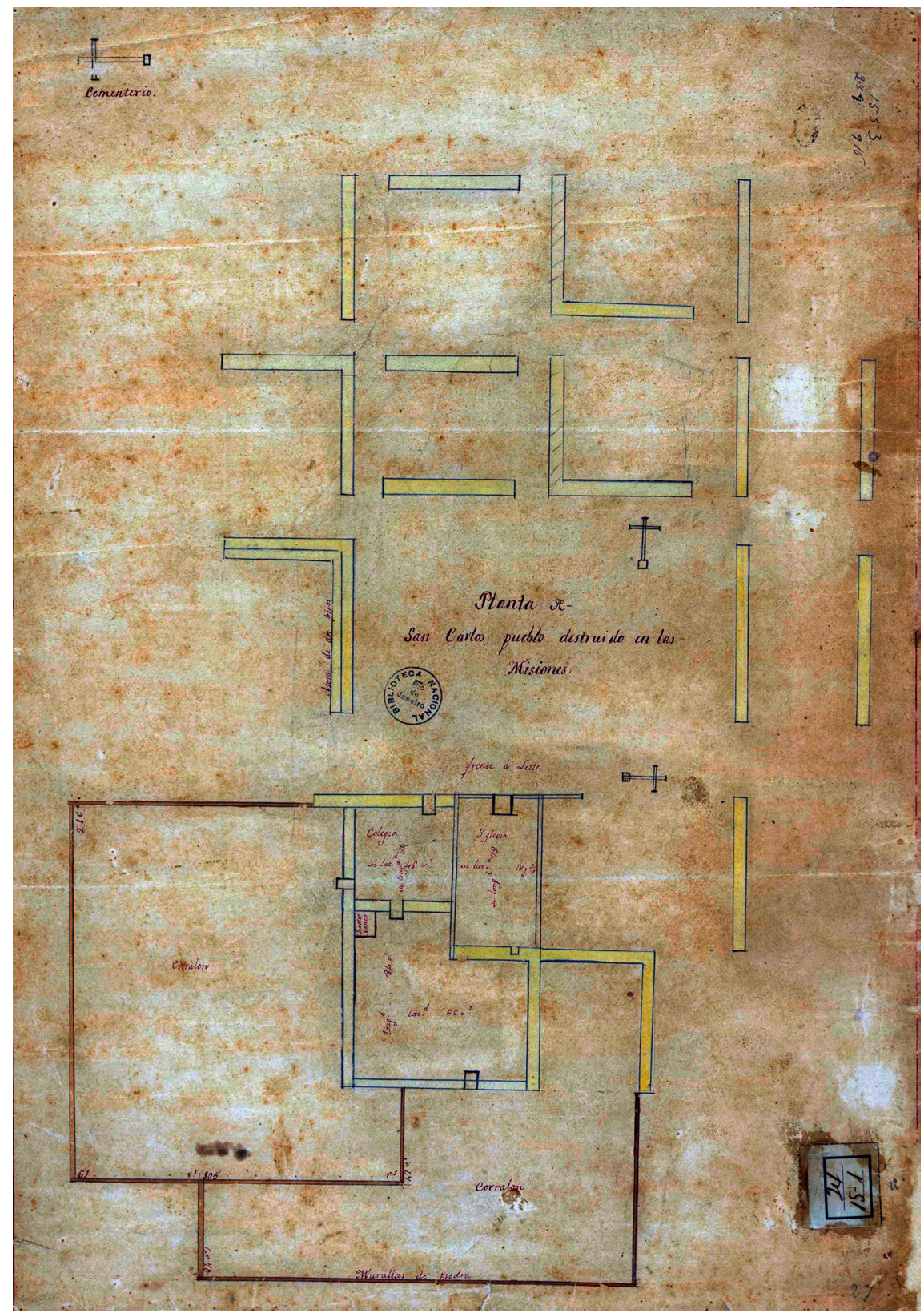

FIGURE 15 A contemporary diagram of the San Carlos mission complex at the time of the 1818 battle 


\subsection{Conclusions}

Born in the crucible of the sixteenth-century Counter-Reformation, the Jesuits also assumed an important role in the cities of Spanish America and in staffing missions on the frontiers of Spanish America. By the mid-eighteenth century, there were more than two thousand Jesuits in Spanish America. However, times were changing, and reform-minded monarchs seeking to enhance their authority saw the Society of Jesus as an impediment rather than a benefit. Portugal ordered the expulsion of the Jesuits from its territories in 1759, France in 1764, and Spain in 1767. King Carlos III declined to give his reasons for the expulsion order. On June 25, 1767, royal officials began the task of arresting the Jesuits in Spanish America and arranging to ship them to Europe where those that survived settled into exile in the Papal States in Italy. The crown confiscated the properties and wealth the exiled Jesuits left behind.

Of immediate concern was finding missionaries to replace the Jesuits on the frontier missions they staffed. Royal officials scrambled to find replacements. On the northern frontier of Mexico, for example, royal officials recruited Franciscans from several apostolic colleges, but adjustments had to be made to find the personnel necessary to staff the former missions, and in some instances missions had to be secularized, or turned over to parish priests subject to episcopal authority. However, there were also long-term consequences, particularly in the Spanish American cities where the Jesuits had played an important educational and cultural role. For the Jesuits, their arrest by royal officials was only the start of an ordeal that would last for several years. Different ships carried the exiled Jesuits to Spain; a document dated June 30 , 1769 provided a detailed final accounting before royal officials had the survivors transferred to Italy.

\section{Conclusion}

Voltaire created a utopian vision of the Jesuits in Spanish America in his fantasy regarding the Jesuit missions among the Guaraní that caught the imagination of the literate Europeans that read his novel Candide. While his novel reflected on the society that Europe could become, it did not reflect historical reality, as this overview to the Society of Jesus in Spanish America has attempted to present. Life on the Guaraní missions was difficult, and there was certainly nothing romantic about it. However, Voltaire's vision of the missions among the Guaraní framed or influenced the ways in which people thought about the role of the Jesuits in Spanish America for generations. 
The Society of Jesus came into existence during a period of conflict following the beginning of the Protestant Reformation that challenged the corruption of the Catholic Church and defined new doctrinal points, and the Catholic Counter-Reformation that attempted to recapture the faithful, correct popular errors in doctrine, and stamp out heresy. The Society of Jesus was unique when compared with other Catholic orders that came to Spanish America. It was an international order that recruited members from different countries, including from among the colonial elites in Spanish America. During much of the history of their presence in Spanish America, this was a point of strength, but in the changed political atmosphere of the mid-eighteenth century it became a liability. The Jesuits also swore an oath of allegiance directly to the pope, and the Society's enemies often referred to the order's superior general as the "Black Pope."

The Jesuits played an important role in Spanish American cities as educators, in the task of correcting doctrinal error, and in promoting the spiritual development of city-folk. The Jesuits had a reputation for the quality of the education they offered. This can be seen, for example, in the case of the mining center of Zacatecas in Mexico. City leaders invited the Jesuits to establish themselves in the city and quickly enrolled their children and offered financial support when they decided to establish a colegio there. The Jesuits educated children and young adults but also encouraged young men to enter the order. They organized novitiates such as that at Tepotzotlán and recruited new members from among Spanish American elite families. The Jesuit urban infrastructure included what was known as the casa profesa where the new members of the order who had almost completed their training resided as a community until they took their final oath of obedience to the pope and became full members of the order.

The Jesuits also played an important role in the spiritual life of urban and rural-folk, a role that reflected the Counter-Reformation agenda of correcting doctrinal error among the faithful and rooting out heresy. The Jesuits, as did the other religious orders, organized what was known as "popular missions" among the faithful to correct doctrinal error. A typical example of this was the popular mission in the 173 os among a group of colonists from the Canary Islands who settled near Montevideo in the previous decade. The Jesuits also developed ways to focus the spirituality of urban-folk. One was through the organization of congregaciones that brought people together to pray, particularly to the devotion to the Virgin. Another was the promotion of the Ignatian Spiritual Exercises, and the Jesuits organized casas de ejercicios that were venues for the pious to practice the exercises and to eat. 
The importance of the Jesuits in Spanish American cities can also be seen, for example, in the role they played in responses to natural disasters and health crises resulting from epidemics. Medical specialists and scientists know that a corona virus is responsible for the current Covid-19 pandemic that has infected millions and killed more than a million people worldwide and more than 230,000 in the United States. In the sixteenth to eighteenth centuries, epidemics spread through the populations of Spanish American cities, and the Jesuits and other religious authorities taught that God sent disease as a punishment for sin. One common response to epidemic outbreaks was the organization of processions and prayer designed to placate God's wrath. The novena staged in Mexico City in 1727 in response to a measles epidemic was an example of this facet of Jesuit spiritual leadership. The residents of Mexico City turned to the Jesuits to direct the response to God's judgment on humanity.

The Jesuits also played an important role in the evangelization of indigenous peoples on the fringes of Spanish America, and in this overview I have given more importance to the examples of missions the Jesuits administered in the Río de la Plata region of South America and northern Mexico. There is one distinction that should be made in terms of the primary activities of the Jesuits in Spanish America. In a real sense, the Jesuit urban mission responded to the church's Counter-Reformation agenda of making sure that the populations that were already ostensibly Catholic complied with basic doctrine and did not fall into error or even worse into heresy. The administration of missions, on the other hand, was more complex, since the Spanish (actually Castilian) crown promoted, sanctioned, and largely financed the evangelization of the indigenous peoples in its American territories by different Catholic orders such as the Franciscans, Augustinians, Dominicans, and Jesuits, among others. In the 1490s, the papacy granted the crown of Castile extensive powers over the church in the Americas in exchange for the crown assuming responsibility for the evangelization of indigenous peoples. The missionaries including the Jesuits functioned as representatives of both the church and the crown, but it was the crown that set the expectations for the outcomes of the missions.

The Jesuits attempted to evangelize and engage in the social engineering of more or less sedentary as well as non-sedentary indigenous peoples. It was the missions among the Guaraní that caught the imagination of contemporary Europeans following the publication of Candide and came closest to fulfilling crown expectations in terms of creating stable indigenous communities on the frontiers. The Jesuits dedicated disproportionally large numbers of personnel to the Río de la Plata region, which was one of the most politically, economically, and demographically marginal areas in Spanish America until the second half of the eighteenth century. In 1750, for example, the Jesuit province of 
Paraquaria ranked third in terms of the total number of personnel in Spanish America, and a 1769 list of expelled Jesuits sent to Spain recorded an equally large number exiled from Paraquaria, including eighty that had been on the missions among the Guaraní. Moreover, the Jesuit missions and particularly those among the Guaraní were disproportionately important economically and demographically in the larger region. In 1732 , the thirty missions among the Guaraní alone had a population of 141,000, far larger than the non-mission population centers. The mission militia, for example, provided the bulk of the "cannon fodder" for military campaigns in support of royal policy such as the conflict with the Portuguese over the disputed borderlands. The outcome of the Spanish-Portuguese conflict and the post-independence boundaries of Argentina, Uruguay, Paraguay, and Brazil might have been different if royal officials had been unable to count on military support from the Jesuit missions.

The missions among the Guaraní had a formal military system that paralleled the political structure on the missions. Royal officials recruited indigenous auxiliaries for campaigns on other mission frontiers, but the Guaraní mission militia was perhaps the only instance of an indigenous military organization that was allowed to use European firearms. Moreover, the militia continued to exist into the early nineteenth century. Documents list the political offices created on the missions associated with the cabildos, but also a military hierarchy with officials that held different ranks. In addition to providing military support to royal officials, the Jesuits also engaged in the geopolitics of the region. In 168o, the Portuguese established Colonia do Sacramento in what today is Uruguay opposite Buenos Aires. The mission militia participated in a military campaign that took the Portuguese settlement, but Spain then returned the settlement to Portugal. In the 168os and 169os, the Jesuits relocated two missions east of the Uruguay River and established four new missions by transferring populations from existing missions. This expansion east of the Uruguay River asserted Spanish claims to disputed territory and cut Colonia do Sacramento off from other Portuguese settlements to the north.

The Jesuits created new mission communities from whole cloth in the missions among the Guaraní as they also did in the cases of the Chaco and Baja California missions. In Sinaloa and Sonora, on the other hand, they established missions in existing indigenous communities. Of the cases examined here, the Jesuits were able to direct the development of large complexes on the missions among the Guaraní oriented on the grid plan as mandated by Spanish law for the Americas. The Jesuits congregated the entire mission populations on the new communities, which was possible because of the availability of arable land and because the Guaraní continued to support themselves through agricultural production on their own subsistence plots. In the more arid regions of Baja 
California and Sonora, on the other hand, they could not, but rather adopted a more dispersed settlement pattern. They also attempted to congregate the different Chaco groups such as the Abipones on the missions, but non-sedentary indigenous groups more frequently resisted Jesuit social engineering.

The Jesuits managed the communal mission economy and sold products to generate income to pay the tribute obligations to the crown of the Guaraní living on the missions and for materials that they needed for the administration of the missions and religious services. The Jesuits paid the tribute so that the Guaraní would not have to leave the missions to look for work to earn income and as a means of controlling the labor supply. The Guaraní mission residents provided labor several days a week for communal production. The Jesuits maintained an extensive network of offices throughout South America for the marketing of mission-produced goods. On the northwestern frontier of Mexico, the Jesuits used surplus agricultural production from the missions in Sinaloa and Sonora to help subsidize the Baja California missions. The missions among the Guaraní achieved the goal of economic self-sufficiency. The missions in Sonora were largely self-sufficient as well, whereas those in Baja California depended on outside subsidies.

The missions among the Guaraní were the most populous of the Jesuit missions in Spanish America, and the largest recorded population for a single mission was that of Yapeyú, which had a population of 8,500 in 1768 at the end of the Jesuit period. The population of this one mission, for example, was larger than that of all of the Baja California missions combined in the same year and was also larger than that of the combined population of the eight Pimería Alta missions in northern Sonora. The Jesuits congregated these large populations in compact communities. This urban plan, however, would have demographic consequences for the Guaraní populations. The missions were connected to other communities in the region by the rivers and engaged in trade. River traffic also facilitated the spread of contagion, and there were epidemics roughly once a generation or about every twenty years once there was a large enough pool of potentially susceptible hosts or the children and young adults born since the previous outbreak. The large number of people living on the missions facilitated the spread of contagion. These and other factors contributed in some cases to catastrophic mortality levels in excess of twenty-five percent of the population of a given mission, and in some cases more than fifty or even sixty percent. However, following epidemics there was a renewed growth of the mission populations with the formation of new families and high birth rates.

These patterns differed from those on the other missions examined here. The case of demographic patterns on the Baja California missions is well documented. Epidemics decimated the indigenous populations congregated on the 
missions in the first decades of the Jesuit presence. However, there is a record of the growth of the numbers on two missions in the last three decades of the Jesuit tenure in the peninsula. Following the Jesuit expulsion in 1767-68, the movement of personnel through the peninsula contributed to the spread of a series of epidemics that killed hundreds, and the indigenous population continued to decline to the point of near cultural and biological extinction in large parts of the peninsula. The Sonora missions, on the other hand, were open populations, which meant that the Jesuits and later the Franciscans that replaced them periodically congregated non-Christians on the missions, which expanded the size of the mission populations. Periodic epidemics also reduced the size of the mission populations. Nevertheless, the Sonora missions survived as identifiable indigenous communities as late as the first decades of the nineteenth century.

The more difficult question is to measure the outcome of the mission programs: In other words, did they achieve the goal of creating stable indigenous communities integrated into Spanish colonial society? The Jesuits came the closest to achieving this goal in the case of the missions among the Guaraní and those in Chiquitania, which we have not examined here but that also formed a part of the province of Paraquaria and that congregated more or less sedentary peoples on new communities created from whole cloth. The missions among the Guaraní continued to exist as viable communities for more than forty years following the Jesuit expulsion. However, after 1810 the mission region became a war zone as the emerging independent countries in the region fought over territory. Marauding armies destroyed most of the mission complexes and dispersed the Guaraní populations. Several mission communities located in what today is southern Paraguay, on the other hand, survived and developed as multi-ethnic communities. The missions of Chiquitania survive to this day as identifiable communities. The indigenous populations of Baja California largely disappeared as a consequence of demographic collapse with the exception of populations located in the mountainous region of the northernmost part of the peninsula. The former missions in Sonora evolved as multi-ethnic communities, and small indigenous populations survived.

The one accounting of the number of Jesuits expelled from Spanish America shows that there was slightly more than two thousand members of the Society in Mexico and South America sent into exile. Some died before leaving the Americas, and others passed away at sea. The Spanish government returned the Jesuits to the pope, and they passed the rest of their lives in the Papal States in Italy. The papacy in turn suppressed the Society of Jesus in 1773 and did not restore the order until 1814. The Spanish crown confiscated the Jesuits' properties and economic resources and had to find replacements for the missions 
they staffed. However, in many ways they could not be replaced in the religious, social, and cultural life of Spain's American territories.

\section{Bibliography}

\section{Archival Sources}

Archivum Romanum Societatis Iesu, Rome (ARSI).

Coleção de Angelis, Biblioteca Nacional, Rio de Janeiro, Brazil (CA).

\section{Published Sources}

Adorno, Rilena, and Patrick Pautz, trans. The Narrative of Cabeza de Vaca. Lincoln, NE: University of Nebraska Press, 2003.

Altman, Ida. The War for Mexico's West: Indians and Spaniards in New Galicia, 1524-1550. Albuquerque: University of New Mexico Press, 2010.

Archer, Christon. The Army in Bourbon Mexico, 1760-1810. Albuquerque: University of New Mexico Press, 1977.

Avellaneda, Mercedes. Guaraníes, criollos y jesuitas: Luchas de poder en las revoluciones Comuneros del Paraguay siglos XVII y XVIII. Asunción: Editorial Tiempo de Historia, 2014.

Bannon, John, S.J. The Mission Frontier in Sonora, 1620-1687. New York: Catholic Historical Society, 1955 .

Barbier, Jacques A. Reform and Politics in Bourbon Chile, 1755-1796. Ottawa: University of Ottawa Press, 1980.

Barco, Miguel del, S.J. Historia natural y crónica de la antigua California: Adiciones y correcciones a la noticia de Miguel Venegas; Edición, estudio preliminar, notas y apéndices por Miguel León-Portilla. Mexico City: Universidad Nacional Autónoma de México, Instituto de Investigaciones Históricas, 1973.

Bécker, Felix. "La guerra guaranítica desde una nueva perspectiva: Historia, ficción e historiografía." Boletín americanista 32 (1982): 7-37.

Bracco, Diego. "Charrúas y aculturación: La primera década en Concepción de Cayastá (1750-1760)." Revista Tefros 14, no. 1 (2016): 6-52.

Bracco, Diego. "Charrúas, bohanes, pampas y guenoa minuanos en los pueblos de misiones." Folia histórica del Nordeste 27 (September-December 2016): 199-212.

Bracco, Diego. "Los guenoa minuanos misioneros." Memoria americana: Cuadernos de etnohistoria 24, no. 1 (2016): 33-54.

Block, David, "Links to the Frontier: Jesuit Supply of Its Moxos Missions, 1683-1767." The Americas 37, no. 2 (1980): 161-78.

Campbell, Leon G. The Military and Society in Colonial Peru, 1750-1810. Philadelphia: American Philosophical Society, 1978. 
Caraman, Philip. The Lost Paradise: The Jesuit Republic in South America. New York: Seabury Press, 1976.

Carbonell de Massy, Rafael, S.J. Estrategias de desarrollo rural en los pueblos guaranies (1609-1767). Barcelona: Antoni Bosch Editor, 1992.

Carbonell de Massy, Rafael, S.J., and Norberto Levinton. Un pueblo llamado Jesús. Asunción: Fundación Paracuaria, 2010.

Chmyz, Igor. "Pesquisas arqueológicas nas reduções jesuíticas do Paraná." Revista do Círculo de Estudos Bandeirantes. Curitiba 15 (2001): 39-58.

Clavijero, Francisco Javier, S.J. Historia de la Antigua o Baja California. Mexico City: Imprenta de Juan R. Navarro, $185^{2}$.

Coello de la Rosa, Alexandre. "La doctrina de Juli a debate (1575-1585)." Revista de estudios extremeños 63, no. 2 (2007): 951-89.

Coronado Aguilar, Jurandir. Conquista espiritual: A história da evangelização na província Guairá na obra de Antonio Ruiz de Montoya, S.J. (1585-1652). Rome: Editrice Pontificia Universitá Gregoriana, 2002.

Cortesão, Jaime. Jesuítas e bandeirantes no Tape (1613-1641). Rio de Janeiro: Biblioteca Nacional, 1969 .

Cunninghame Graham, Robert Bontine. A Vanished Arcadia: Being Some Account of the Jesuits in Paraguay 1607-1767. London: William Heinemann, 1901.

Cushner, Nicholas. Farm and Factory: The Jesuits and the Development of Agrarian Capitalism in Colonial Quito. Albany, NY: SUnY Press, 1982.

Cushner, Nicholas. Jesuit Ranches and the Agrarian Development of Colonial Argentina, 1650-1767. Albany, NY: sunY Press, 1984.

Cushner, Nicholas. Lords of the Land: Sugar, Wine, and Jesuit Estates of Coastal Peru, 1600-1767. Albany, NY: SUNY Press, 198 o.

Díaz, Marco. "El patronazgo en las iglesias de la Nueva España: Documentos sobre la Compañía de Jesús en Zacatecas en el siglo XVII." Anales del Instituto de Investigaciones Estéticas 13, no. 45 (1976): 97-105.

Dobyns, Henry F. "An Appraisal of Techniques with a New Hemispheric Estimate." Current Anthropology 7, no. 4 (1966): 395-416.

Dobyns, Henry F. Their Number Become Thinned: Native American Population Dynamics in Eastern North America. Knoxville: University of Tennessee Press, 1983.

Dunne, Peter Masten, S.J. Black Robes in Lower California. Berkeley: University of California Press, $195^{2}$.

Dunne, Peter Masten, S.J. Pioneer Black Robes on the West Coast. Berkeley and Los Angeles: University of California Press, 1940.

Erbig,Jeffrey. Where Caciques andMapmakersMeet:BorderMakinginEighteenth-Century South America. Chapel Hill: University of North Carolina Press, 2020.

Gerhard, Peter. La frontera norte de la Nueva España. Mexico, DF: UNAM, 1996. 
Gómez Canedo, Lino. Sierra Gorda: Un típico enclave misional en el centro de México (siglos xvii y xviii). Querétaro: Dirección de Patrimonio Cultural, Secretaría de Cultura y Bienestar Social del Estado de Querétaro, 1988.

González Rissotto, Luis Rodofo. "La importancia de las misiones jesuíticas en la formación de la sociedad Uruguaya." Estudios ibero-americanos 15, no. 1 (1989): 191-214.

Gordillo Claure, Jose, and Robert H. Jackson. "Formación, crisis y transformación de la estructura agraria de Cochabamba: El caso de la hacienda de Paucarpata y de la comunidad del Passo, 1538-1645 y 1872-1929." Revista de Indias 53, no. 199 (September-December 1993): 723-6o.

Greentree, David. A Far-Flung Gamble: Havana 1762. London: Osprey, 2010.

Gutiérrez, Ramón. "Propuestas urbanísticas de los sistemas misionales de los jesuitas." In Un reino en la frontera: Las misiones jesuitas en la América colonial, edited by Sandra Negro Tua and Manuel María Marzal, 173-83. Quito: Abya Yala, 2000.

Gutiérrez Casillas, José, S.J. Diccionario bio-bibliográfico de la Compañía de Jesús en México: Tomo 16 Siglo XVIII A-K. Mexico City: Editorial Tradición, 1977.

Gutiérrez Casillas, José, S.J. Diccionario bio-bibliográfico de la Compañía de Jesús en México: Tomo 15 Siglo XVIII L-Z. Mexico City: Editorial Tradición, 1977.

Hale, Frederick. "Literary and Cinematic Representations of Jesuit Missions to the Guaraní of Paraguay, with Special Reference to the Film and Novel of 1986, The Mission." PhD diss., University of South Africa, 1997.

Helmar, Marie. "Juli, un experimento misionero de los jesuitas en el altiplano andino (siglo XVI)." Boletín IRA 12 (1983): 191-216.

Jackson, Robert H. "The 1781-1782 Smallpox Epidemic in Baja California." Journal of California and Great Basin Anthropology 3, no. 1 (1981): 138-43.

Jackson, Robert H. "The Changing Economic Structure of the Alta California Missions: A Reinterpretation." Pacific Historical Review 61, no. 3 (1992): 387-415.

Jackson, Robert H. "La colonización de la Alta California: Un análisis del desarrollo de dos comunidades misionales." Historia mexicana 41 (1991): 83-110.

Jackson, Robert H. Communities on a Frontier in Conflict: The Jesuit Guarani Mission Los Santos Martires del Japon. Newcastle upon Tyne: Cambridge Scholars Publishing, 2018.

Jackson, Robert H. Demographic Change and Ethnic Survival among the Sedentary Populations in the Jesuit Mission Frontiers of Spanish South America, 16o9-1803: The Formation and Persistence of Mission Communities in a Comparative Context. Leiden: Brill, 2015.

Jackson, Robert H. "Demographic Change in Northwestern New Spain." The Americas 41, no. 4 (April 1985): 462-79.

Jackson, Robert H. "Demographic Patterns in the Jesuit Missions of the Río de la Plata Region: The Case of Corpus Christi, 1622-1802." Colonial Latin American Historical Review 13, no. 4 (2004): 337-66. 
Jackson, Robert H. "Demographic Patterns in the Missions of Central Baja California." Journal of California and Great Basin Anthropology 6, no. 1 (1984): 91-112.

Jackson, Robert H. "Demographic and Social Change in Northwestern New Spain: A Comparative Analysis of the Pimeria Alta and Baja California Missions." Master's thesis, University of Arizona, 1982.

Jackson, Robert H. "Eighteenth-Century Supply System in Texas and California: The Development of Mission Economics." In Francis in America: Essays on the Franciscan Family in North and South America, edited by John F. Schwaller, 277-93. Berkeley: Academy of American Franciscan History, 2005.

Jackson, Robert H. Frontiers of Evangelization: Indians in the Sierra Gorda and Chiquitos Missions. Norman, OK: University of Oklahoma Press, 2017.

Jackson, Robert H. "The Guaycuros, Jesuit and Franciscan Missionaries, and José de Gálvez: The Failure of Spanish Policy in Baja California." Memoria americana 12 (2004): 221-33.

Jackson, Robert H. “The Impact of Liberal Policy on Mexico's Northern Frontier: Mission Secularization and the Development of Alta California, 1812-1846." Colonial Latin American Historical Review 2, no. 2 (1993): 195-225.

Jackson, Robert H. Indian Population Decline: The Missions of Northwestern New Spain, 1687-1840. Albuquerque: University of New Mexico Press, 1994.

Jackson, Robert H. "Una mirada a los patrones demográficos de las misiones jesuitas de Paraguay." Fronteras de la historia 9 (2004): 129-78.

Jackson, Robert H. "Missions on the Frontiers of Spanish America." Journal of Religious History 33, no. 3 (September 2009): 328-47.

Jackson, Robert H. Missions and Frontiers of Spanish America: A Comparative Study of the Impact of Environmental, Economic, Political, and Socio-cultural Variations on the Missions in the Río de la Plata Region and on the Northern Frontier of New Spain. Scottsdale, AZ: Pentacle Press, 2005.

Jackson, Robert H. Pames, Jonaces, and Franciscans in the Sierra Gorda: Mecos and Missionaries. Newcastle upon Tyne: Cambridge Scholars Publishing, 2017.

Jackson, Robert H. "Patrones demográficos de una frontera en conflicto: Las siete misiones orientales de la provincia jesuítica de Paraguay, 1680-183o." Unpublished paper presented at the Seminário Internacional: Indígenas, Missionários e espanhóis o Paraná no contexto da Bacia do Prata, séculos XVI e XVII, Paraná, October 15-17, 2008.

Jackson, Robert H. “La población y tasas vitales de las misiones jesuíticas de los Guaraní (Argentina, Brasil, Paraguay)." IHS: Antiguos jesuitas en Iberoamérica 5, no. 2 (JulyDecember 2017): 100-65.

Jackson, Robert H. "Population and the Economic Dimension of Colonization in Alta California: Four Mission Communities." Journal of the Southwest 33 (1991): $387-439$. 
Jackson, Robert H. A Population History of the Jesuit Province of Paraquaria. Newcastle upon Tyne: Cambridge Scholars Publishing, 2019.

Jackson, Robert H. Regional Conflict and Demographic Patterns among the Guaraní in the Seventeenth and Eighteenth Centuries. Leiden: Brill, 2019.

Jackson, Robert H. Regional Markets and Agrarian Transformation in Bolivia: Cochabamba, 1539-1960. Albuquerque: University of New Mexico Press, 1994.

Jackson, Robert H. A Visual Catalog of Spanish Frontier Missions, 16th to 19th Centuries. Newcastle upon Tyne: Cambridge Scholars Publishing, 2018.

Koebel, William Henry, and Robert Bontine Cunninghame Graham. In Jesuit Land: The Jesuit Missions of Paraguay. London: S. Paul, 1912.

Kuethe, Allan J. Military Reform and Society in New Granada, 1773-1808. Gainesville, FL: University Presses of Florida, 1978.

Kuethe, Allan J., and Kenneth J. Andrien. The Spanish Atlantic World in the Eighteenth Century: War and the Bourbon Reforms, 1713-1796. Cambridge: Cambridge University Press, 2014.

Levinton, Norberto. "Las estancias de Nuestra Señora de los Reyes de Yapeyú: Tenencia de la tierra por uso cotidiano, acuerdo interétnico y derecho natural (Misiones jesuíticas del Paraguay)." Revista complutense de historia de América 31 (2005), 33-51.

Levinton, Norberto. "Guaraníes y charrúas: Una frontera exclusivista-inclusivista." Revista de história regional 14, no. 1 (Summer 2009): 49-75

Maeder, Ernesto. Una aproximación a las misiones guaraníticas. Buenos Aires: Universidad Católica Argentina, 1996.

Malaga Sabogal, Ximena. "Juli, la Roma de América: Memoria, construcción y percepciones del pasado jesuita en un pueblo del altiplano." Thesis for the licenciate, Pontificia Universidad Católica del Perú. Facultad de Ciencias Sociales, 2011.

Martínez Martín, Carmen, and Rafael Carbonell de Massy. “Análisis comparativo de las 'Cartas anuas' de la provincia jesuítica del Paraguay (1618-1619) con dos documentos previos." Revista complutense de historia de América 18 (1992):159-78.

Montero Alarcón, Alma. Jesuitas de Tepotzotlán: La expulsión y el amargo destierro. Mexico City: INAH, 2014.

Nieto Velez, Armando, S.J. "Jesuitas en el mundo andino: Las reducciones de Juli." Revista peruana de historia eclesiástica 2 (1994): 129-44.

Nonneman, Walter. "On the Economics of the Socialist Theocracy of the Jesuits in Paraguay (1609-1767)." In The Political Economy of Theocracy, edited by Ronald Wintrobe and Mario Ferrero, 119-42. New York: Palgrave Macmillan, 2009.

Nowell, Charles E. “The Defense of Cartagena." Hispanic American Historical Review 42, no. 4 (1962): 477-501.

Ortiz, Eduardo L. "The Jesuits and the Exact Sciences in Argentina." In Cultural Worlds of the Jesuits in Colonial Latin America, edited by Linda Newsom, 255-83. London: Institute of Latin American Studies, School of Advanced Study, University of London, $202 \mathrm{O}$. 
Page, Carlos. La estancia jesuítica de Alta Gracia. Córdoba: Universidad Católica de Córdoba, 2000.

Page, Carlos. La reducción jesuítica de Santa Rosa y su Capilla de Loreto. Asunción del Paraguay: Fotosíntesis editora, 2015.

Parellada, Claudia. "El Paraná español: Ciudades y misiones jesuíticas en Guairá." In Missoes: Conquistando almas e territorios, 130-39. Curitiba: Governo do Paraná, 2009.

Quarleri, Lia. "Gobierno y liderazgo jesuítico-guaraní en tiempos de guerra (17521756)." Revista de Indias 68:243 (2008), 89-114.

Quarleri, Lia. Rebelión y guerra en las fronteras del Plata: Guaraníes, jesuitas e imperios coloniales. Buenos Aires: Fondo De Cultura Económica, 2009.

Radding de Murrieta, Cynthia. "From the Counting House to the Field and Loom: Ecologies, Cultures, and Economics in the Missions of Sonora (Mexico) and Chiquitanía (Bolivia)." Hispanic American Historical Review 81, no. 1 (2001): 45-87.

Recéndez Guerrero, Emilia. Llegado de la Compañía de Jesús a un centro minero Zacatecas (1592-1767). Zacatecas: Universidad Autónoma de Zacatecas, 2013.

Rex Galindo, David. To Sin No More: Franciscans and Conversion in the Hispanic World 1683-1830. Stanford, CA: Stanford University Press, 2017.

del Río, Ignacio. Conquista y aculturación en la California jesuítica, 1697-1768. Mexico City: Instituto de Investigaciones Históricas, Universidad Nacional Autónoma de México, 1984.

del Río, Ignacio. El régimen jesuítico de la Antigua California. Mexico City: Instituto de Investigaciones Históricas, Universidad Nacional Autónoma de México, 2003.

Robinson, William, and Mark Barnes. "Mission Guevavi: Excavations in the Convento." The Kiva 42, no. 2 (Winter 1976): 135-75.

Ruiz Martínez-Cañavate, Pablo. "Ciudad y territorio en las misiones jesuíticas de indios guaraníes.” In La Compañía de Jesús y las artes: Nuevas perspectivas de investigación, 259-78. Zaragoza: Universidad de Zaragoza, 2014.

Ruiz Martínez-Cañavate, Pablo. "Reducciones jesuíticas del Paraguay: Territorio y urbanismo." PhD diss., Universidad de Granada, 2017.

Ruiz Medrano, Carlos. "El tumulto de 1767 en Guanajuato." Estudios de historia novohispana 19 (1999): 13-46.

Saeger, James. The Chaco Mission Frontier: The Guaycuruan Experience. Tucson, AZ: University of Arizona Press, 2000.

Salinas, María Laura. "San Fernando del Río Negro: Un Intento evangelizador jesuítico a los Abipones." Diálogos 13, no. 2 (2009), 293-322.

Salinas, María Laura, and Julio Folkenand, eds. Cartas anuas de la provincia jesuítica del Paraguay 1714-1720, 1720-1730, 1730-1735, 1735-1743, 1750-1756, 1756-1762. Asunción: Centro de Estudios Antropológicos de la Universidad Católica, 2017.

Sánchez Pichardo, Pablo. "Las danzas de pascola y venado: Su cultura material y comportamiento ritual." Anales de antropología 46 (2012): 135-53. 
Sarreal, Julia. The Guarani and Their Missions: A Socioeconomic History. Stanford, CA: Stanford University Press, 2014.

Seymour, Deni. "Father Kino's 'Neat Little House and Church' at Guevavi." Journal of the Southwest 51, no. 2 (Summer 2009): 285-316.

Tracy, Nicholas. Manila Ransomed: The British Assault on Manila in the Seven Years War. Exeter: University of Exeter Press, 1995.

Vargas Arana, Paola. "Pedro Claver y la evangelización en Cartagena: Pilar del encuentro entre africanos y el Nuevo Mundo, siglo XVII." Fronteras de la historia 11 (2006): 293-328.

Venegas, Miguel. Noticia de la California, y de su conquista temporal, y espiritual hasta el tiempo presente: Sacada de la historia manuscrita, formada en México año de 1739. Valladolid: Editorial Maxtor, 2013.

Vianna, Helio. Jesuítas e Bandeirantes no Uruguai (1611-1758). Rio de Janeiro: Biblioteca Nacional, 1951.

Vianna, Helio. Jesuitas e Bandeirantes no Uruguai (1611-1758). Rio de Janeiro: Biblioteca Nacional, 1970 .

Venkataraman, Vijaya. "Fictional Missions': Representations of Jesuit Encounters in Paraguay." In St. Francis Xavier and the Jesuit Missionary Enterprise: Assimilations between Cultures/San Francisco Javier y la empresa misionera jesuita: Asimilaciones entre culturas, edited by Ignacio Arellano and Carlos Mata Induráin, 305-17. Pamplona: Servicio de Publicaciones de la Universidad de Navarra, 2012.

Wilde, Guillermo. Religión y poder en las misiones de Guaraníes. Buenos Aires: Editorial $\mathrm{Sb}, 2009$.

Zulueta, Julian de. "Health and Military Factors in Vernon's Failure at Cartagena." Mariner's Mirror 78, no. 2 (1992): 127-41. 